University of Louisville

ThinkIR: The University of Louisville's Institutional Repository

Electronic Theses and Dissertations

$5-2018$

\title{
The disjointed moment : marking, mapping, and making the real in William Eggleston's election eve (1976).
}

Joel Darland

University of Louisville

Follow this and additional works at: https://ir.library.louisville.edu/etd

Part of the American Art and Architecture Commons, Modern Art and Architecture Commons, Photography Commons, and the Theory and Criticism Commons

\section{Recommended Citation}

Darland, Joel, "The disjointed moment : marking, mapping, and making the real in William Eggleston's election eve (1976)." (2018). Electronic Theses and Dissertations. Paper 2931.

https://doi.org/10.18297/etd/2931

This Master's Thesis is brought to you for free and open access by ThinkIR: The University of Louisville's Institutional Repository. It has been accepted for inclusion in Electronic Theses and Dissertations by an authorized administrator of ThinkIR: The University of Louisville's Institutional Repository. This title appears here courtesy of the author, who has retained all other copyrights. For more information, please contact thinkir@louisville.edu. 
THE DISJOINTED MOMENT: MARKING MAPPING AND MAKING THE REAL IN WILLIAM EGGLESTON'S ELECTION EVE (1976)

\author{
By \\ Joel Darland \\ B.A. Georgetown College 2010

\begin{abstract}
A Thesis
Submitted to the Faculty of the

College of Arts and Sciences of the University of Louisville in Partial Fulfillment of the Requirements

for the Degree of
\end{abstract}

Master of Arts

in Art(c) and Art History

Hite Art Institute

University of Louisville

Louisville, Kentucky

May 2018 



\title{
THE DISJOINTED MOMENT: MARKING, MAPPING, AND MAKING THE REAL
} IN WILLIAM EGGLESTON'S ELECTION EVE (1976)

\author{
By \\ Joel Darland \\ B.A. Georgetown College 2010 \\ A Thesis Approved on
}

April 24, 2018

By the following Thesis Committee:

\begin{tabular}{c}
\hline $\begin{array}{c}\text { Dr. Jongwoo Jeremy Kim } \\
\text { Thesis Director }\end{array}$ \\
\hline $\begin{array}{c}\text { Dr. Chris Reitz } \\
\text { Second Committee Member }\end{array}$ \\
\hline Paul Martineau \\
Third Committee Member
\end{tabular}




\section{DEDICATION}

This thesis is dedicated to my parents

Dr. Charles and Suzanne Darland

who have been truly selfless in their love and support. 


\section{ACKNOWLEDGEMENTS}

I would like to thank my advisor and mentor Dr. Jongwoo Jeremy Kim for his ample encouragement, criticism, and steady guidance. I would also like to thank the other members of my committee, Dr. Chris Reitz and Paul Martineau, for their time, insightful comments, and contributions. I would also like to thank Dr. Karl Swinehart for helping to water this project's initial seeds. I would also like to thank Alisa Reynolds for helping me find my current path. I would also like to thank Dr. Jim Murley for his enthusiasm and encouragement. I would also like to thank Miranda Lash and the Speed Art Museum for the opportunity to work with many of the photographs featured in this thesis. I would also like to thank Stephen Riley for graciously allowing access to copies of books and photographs in his collection as well as his knowledge and insight. Finally, I would like to express my deepest thanks and gratitude to my family, especially my parents, for their endless love, support, patience, and encouragement. I could not have done it without you. 


\begin{abstract}
THE DISJOINTED MOMENT: MARKING, MAPPING, AND MAKING THE REAL IN WILLIAM EGGLESTON'S ELECTION EVE (1976)
\end{abstract}

Joel Darland

April 24, 2018

This thesis analyzes the photographic book Election Eve (1976) produced by photographer William Eggleston. Eggleston's photographs represent a complex network of connections between material objects and the potential truth of depiction. The oftennondescript locations that Eggleston photographed in Sumter County, GA in October 1976 appear specific at the outset, but quickly lose their adherence to the supposed realities that they depict. Since his first major exhibition in the mid 1970s, Eggleston's photographs have presented difficulty because they from often-disparate material sources. Despite of the complexity of Eggleston's engagement with both art and non-art photography, scholarship continues describe Eggleston's "snapshot aesthetic" as a means of the visualization of things like identities or the banality of its subjects. Yet his practice, typified by Election Eve, is in fact aligned with an attempt to assert the material presence of the photographic object and the role it plays in the construction of reality. Often, this follows Roland Barthes's concept of the "reality effect" in which photographs become reality's surrogates because they appear to prove what reality says about itself. In the course of my investigation, I outline several socio-historical uses of the photograph such as the in archives discussed by Allan Sekula, the private family snapshot analyzed by 
Roland Barthes, and the middleclass photo albums and slideshows analyzed by Pierre Bourdieu. These likewise function in accordance with the reality effect. My purpose is to position Election Eve in relation to its formal sources in order to better understand how the photograph is expected to participate in the world. In relation to Election Eve, this is to elucidate the ways in which the book both represents and asserts its concomitant realities through its deployment and subversion of the photograph's assumed functions. Additionally, I will locate Eggleston's formal and aesthetic predilections in the context of several of his contemporaries who likewise engage in a radical deployment of color photography's amateur baggage. These include William Christenberry, Eve Sonneman, and Stephen Shore. Christenberry's Brownie snapshots of rural Hale County Alabama, Sonneman's diptychs exploring time and space in relation to the photographic moment, and Shore's road trip documents of the towns and cities along US highways will aid in an understanding of the photographic object's use as a physical marker and delineator of truth.

This discussion of photography's materialism is further guided by several theoretical signposts. This includes Bruno Latour's conception of the Thing, a site where concepts and concerns can gather together. The photograph is such a Thing: its material presence represents a gathering place for the often-contentious negotiations made between the world and its depictions and the consensual production of reality. In this sense, the materialism of Election Eve is a product of its ability to affect rather than reflect the world. Instead of a series of images that describe the identities of established places, Election Eve constitutes a set of objects whose material forms, such as the individual print or the leather-bound album, engage, subvert, and reassess the historical 
and social uses and definitions of the photograph and its relationship to reality. This is typified through the role the photograph plays as a landmark and the broader connections between mapped places and the material form of the map. In this way, photographs of roads and road signs, buildings and fields, come together as a web of points that mark off, map, and finally make their own reality. Taken together, the experience of shuffling through the pages, from one decrepit porch to another, from a sunlit but empty diner to a deserted parking lot and a red clay cemetery, provides a sense of anchored reality despite the relative anonymity of content. Apart from their function as seemingly transparent vehicles for history, identity, and the colors of reality, Eggleston's book and its photographs are a network of signposts and landmarks that point to themselves as a place whose material presence is also the presence of reality. 


\section{TABLE OF CONTENTS}

AKNOWLEDGEMENTS




\section{LIST OF FIGURES}

FIGURE

PAGE

1. Stephen Harvard's map of Sumter County, GA ............................................... 3

2. W. Morris Smith, Dedication of Monument on Bull Run Battle-Field, 1865 .......... 4

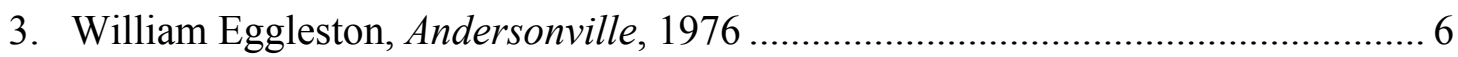

4. Timothy H. O’Sullivan, A Harvest of Death, Gettysburg, Pennsylvania, 1863 ...... 21

5. John Reekie, A Burial Party, Cold Harbor, Virginia, 1865 ................................. 23

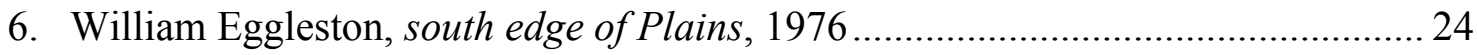

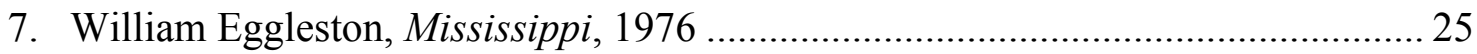

8. William Christenberry, Building with False Brick Siding, Warsaw, Alabama,

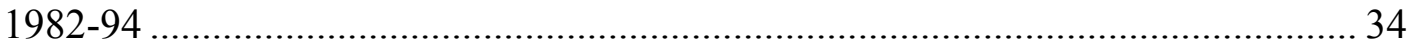

9. Eve Sonneman, Landscape/Cloud, New Mexico, 1978 ........................................ 36

10. Eve Sonneman, The Instant and the Moment, Greece, 1977 ............................... 38

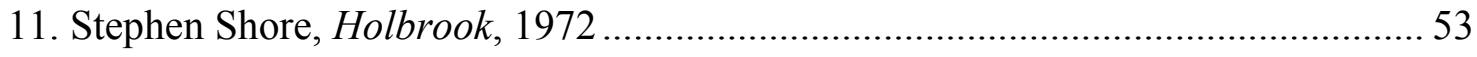

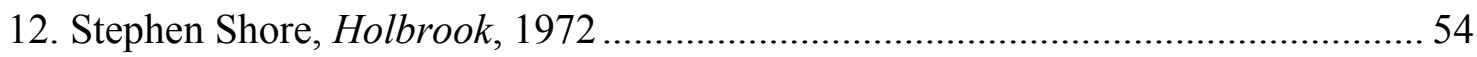

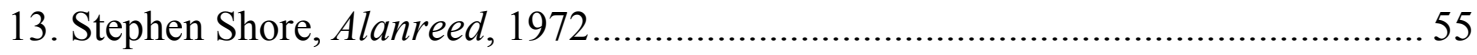

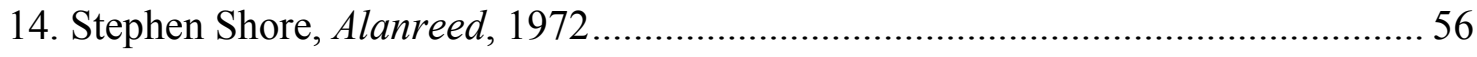

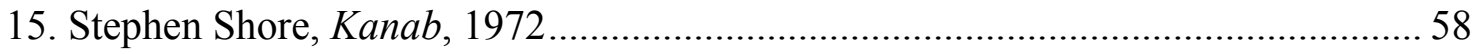

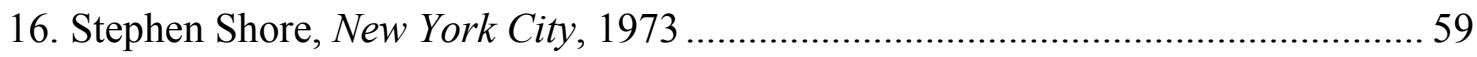

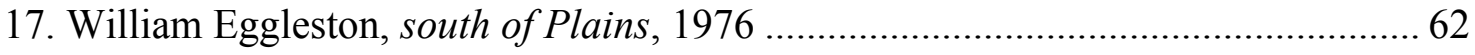

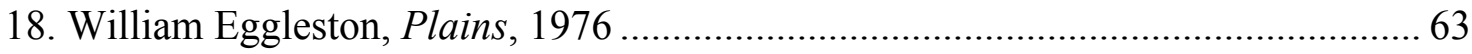


19. William Eggleston, Sumter, 1976 64

20. William Eggleston, side yard, unkempt house, Plains, 1976. 67

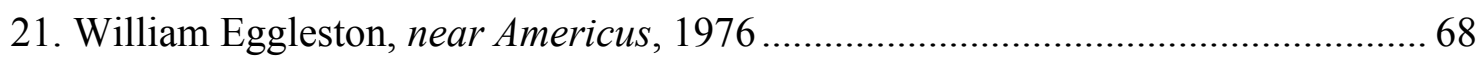

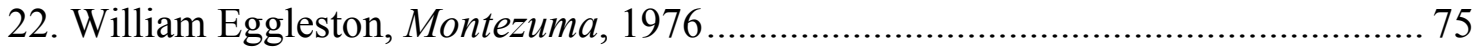

23. William Eggleston, Main Street, facing East, Plains, 1976 ................................. 76

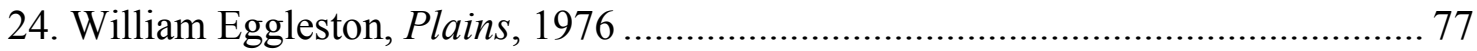

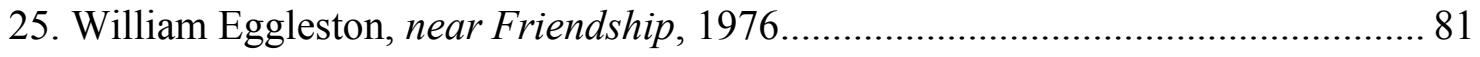

26. William Christenberry, Palmist Building (Summer/Winter), Havana Junction,

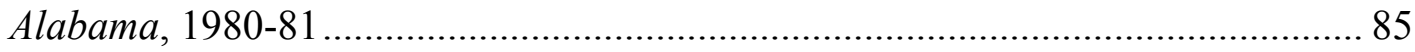

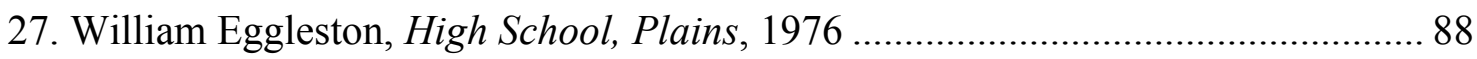

28. William Eggleston, Lutheran Church, Plains, 1976........................................... 89

29. James Van der Zee, Family Portrait, 1926...................................................... 92

30. Unknown photographer, Berthe and Léon Barthes and their daughter Alice,

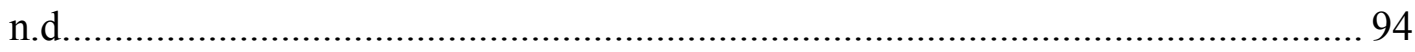

31. William Eggleston, Snak Shak, Montezuma, 1976 .......................................... 99

32. William Eggleston, old jail, Smithfield, 1976................................................ 105

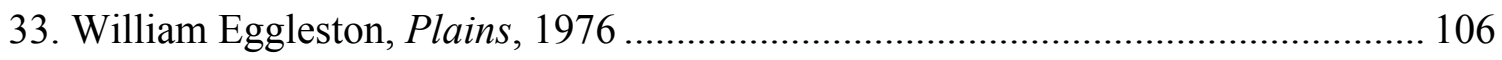

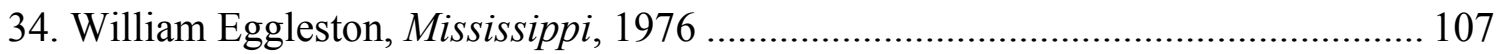

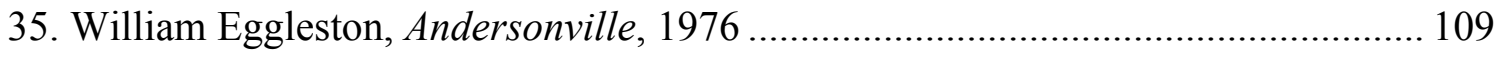




\section{CHAPTER I}

At times banal, mysterious, physically cumbersome, American photographer William Eggleston's first published folio has remained hidden away from the public for the majority of its existence. ${ }^{1}$ Election Eve first appeared in 1977 in an edition of seven and quickly became the sole province of museum and private collections. As a rare commodity, the book's exposure to a wider audience has been almost entirely piecemeal. Individual photographs taken while Eggleston traveled through Sumter County, GA in October 1976 have appeared in exhibitions and publications, but the full extent of what was originally an assignment from Rolling Stone Magazine to take pictures of presidential candidate Jimmy Carter and his family on their home turf has remained largely splintered. The magazine feature never happened and the project became something else entirely. This "sketchbook portrait" of a time and place was instead privately published by Eggleston's friend Caldecott Chubb. ${ }^{2}$ The result was a set of two large leather-bound volumes each with fifty chromogenic color prints mounted on thick cotton-rag paper. The pages were neither numbered nor the prints directly titled. Housed in a large hinged box, Election Eve is a formidable object that requires both time and effort to fully explore. In late 2017, German publisher Steidl reissued the folio. While this new edition states that it follows the same structure as its predecessor, its form, 
dimensions, and materials differ significantly. ${ }^{3}$ In the end it is a facsimile, a fact that intentionally or not rests at the core the book's critical import.

As a book, Election Eve's general structure is modeled after another collection of photographs. ${ }^{4}$ In 1866 Alexander Gardner published a folio of pictures taken following the course of Union Army operations during the American Civil War between 1863 and $1865 .^{5}$ While the dimensions of Election Eve are nearly twice that of Gardner's Photographic Sketch Book of the War, both are clad in glossy leather with embossed gold titles, feature fine marbled paper, and include the same number of photographs equally split between two volumes. Where Gardner's Sketch Book features monumentalizing captions written by Gardner to accompany each plate, Election Eve's images are presented with no comment, notwithstanding a preface by Lloyd Fonvielle and a list of titles and a map (Figure 1) placed at the end of each volume. ${ }^{6}$ The resemblance between the two books manifests through their specific formal properties and the shared symbolic, historical, and social implications embedded in them. Even though their consideration of their statuses as art objects differs, these two photographic books might be read in the same way according to a shared script that designates a material or objective use despite generally divergent content and reception. ${ }^{7}$

Gardner's Sketchbook depicts literal battlefields while Election Eve's title alludes to a relatively bloodless yet still overtly political struggle. Beyond the parallels of conflict, their points of overlap, especially in connections between concepts and geography, are quite complicated. The final photograph of Gardner's Sketch Book, titled Dedication of Monument on Bull Run Battle-Field (1865) (Figure 2), shows a large group of well-dressed men, women, and children who stand in front of a recently dedicated 


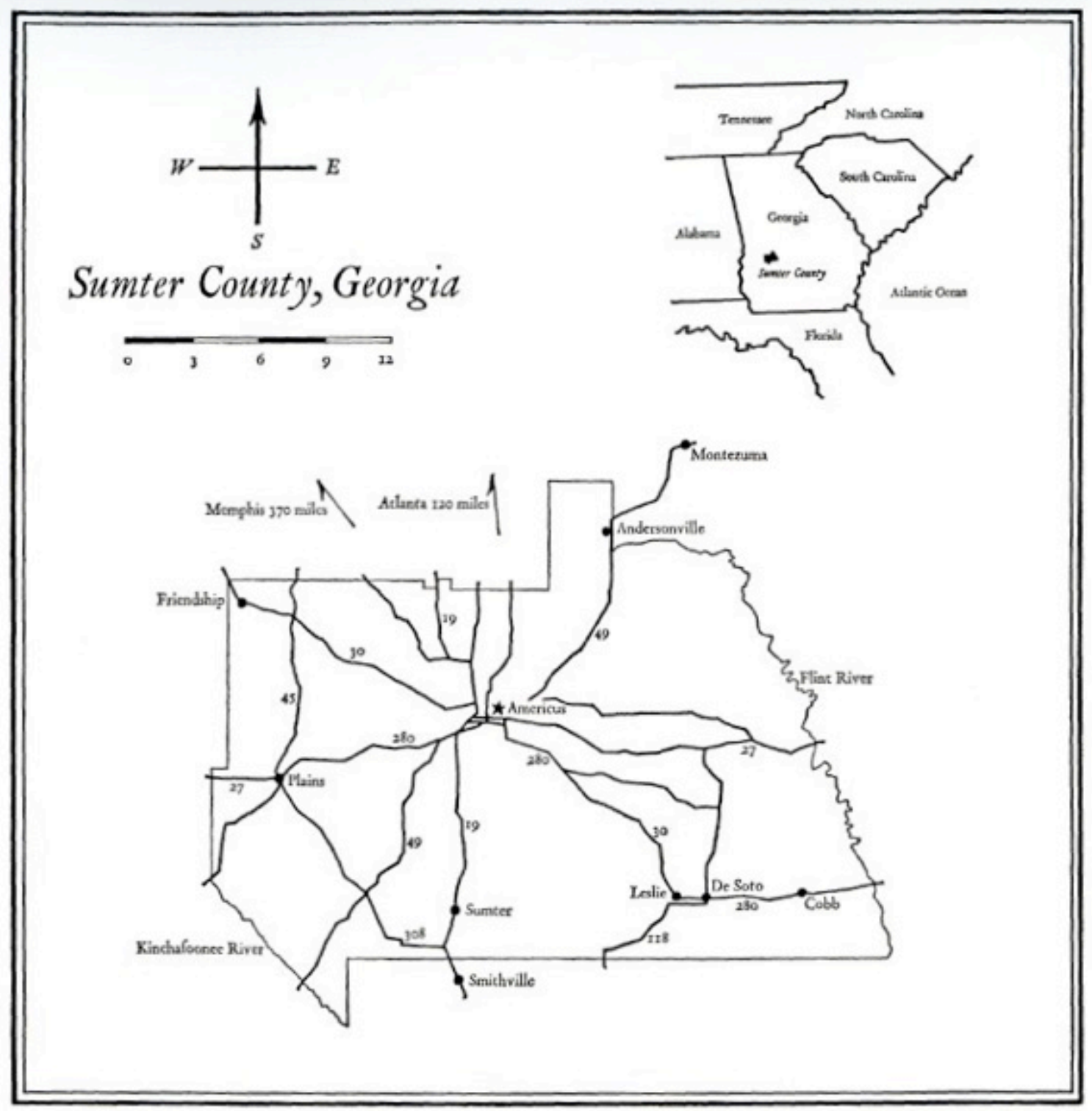

Figure 1. Stephen Harvard's map of Sumter County, GA reproduced at the end of each of Election Eve's two volumes. 


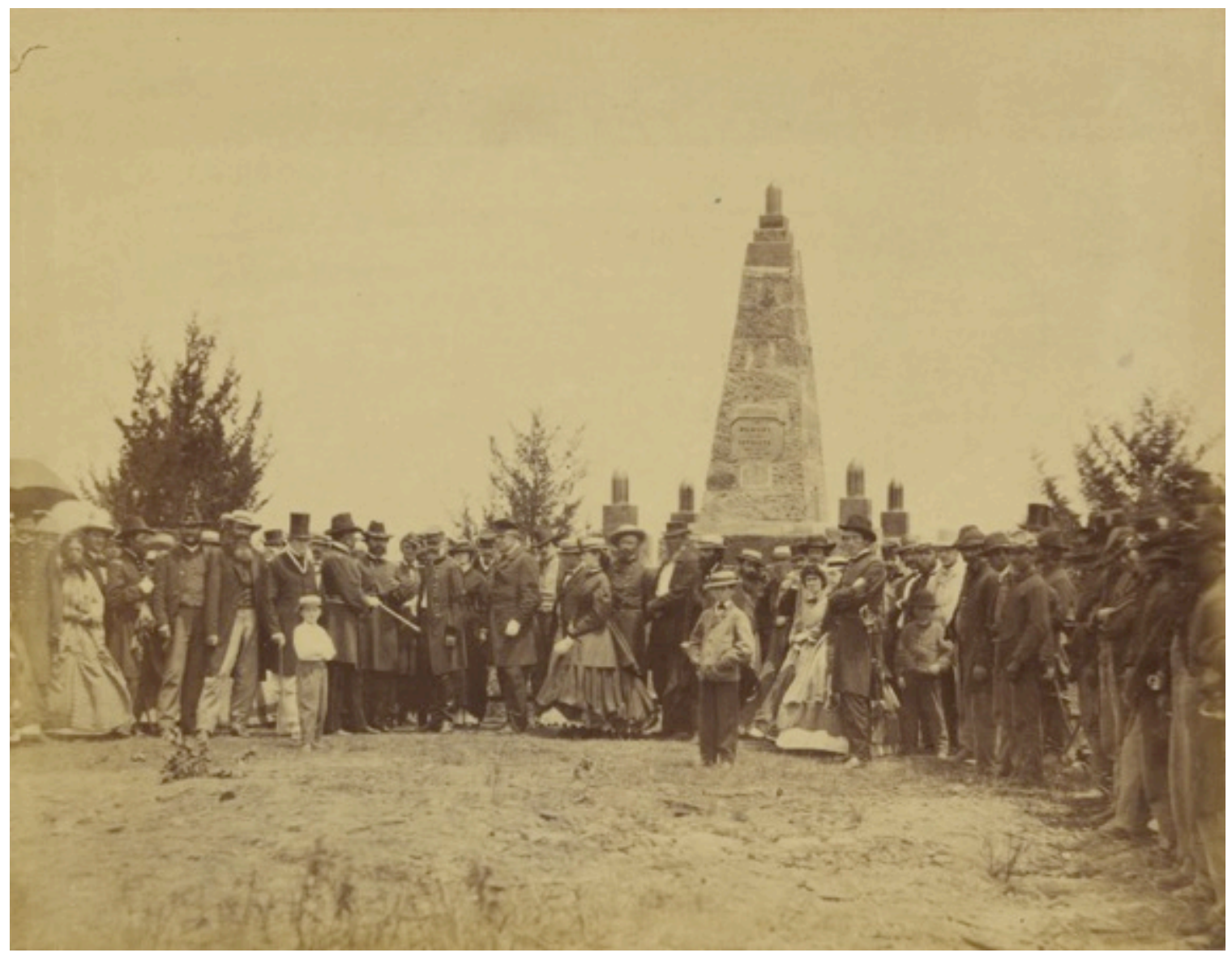

Figure 2. W. Morris Smith, Dedication of Monument on Bull Run Battle-Field, 1865, Albumen silver print from glass negative, 7 x 8 15/16 in. 
monument to the Union casualties of the Battle of Bull Run. As an extension and departure, the final photograph of Election Eve depicts a gnarled tree, shaped and oriented much like the Bull Run monument, among the weeds and scrub of an overgrown field. Titled Andersonville (Figure 3), the photograph references the site where thousands of Union prisoners of war were held and where many subsequently died. While the photograph from Gardner's Sketch Book depicts a monument that stands for continued presence, Andersonville's scene stresses absence. Despite this contrast each is a photographic representation of remembrance. On their faces, these two books connect through both specific points and in overall form and structure. Shared formal and conceptual qualities provide a framework for understanding Election Eve as a sign beyond the literal depictions of its prints. Through the experience of the object and the signifying function of resemblance, the reader can ascertain the "truth" of what it is about, one informed by the contingent ideologies that the object carries. This confluence of signs contributes to what Roland Barthes identifies as the "true-to-life" appearance of its many parts as a cohesive whole. ${ }^{8}$ This also forms the basis of what anthropologist Webb Keane calls "semiotic ideology." In this case, Election Eve is provided a set of instructions by way of historical, artistic, and formal precedents in the object Gardner's Sketch Book that gives the viewer a starting point for understanding its legibility as a sign.

Yet this comparison of endpoints is also the starting point for the difficulties in Eggleston's photographs. The role of such resemblances in his practice drills into deeper and muddier territory and plays at an engagement with the historical burden of photography's use as a tool in the construction of knowledge, truth, and ultimately 


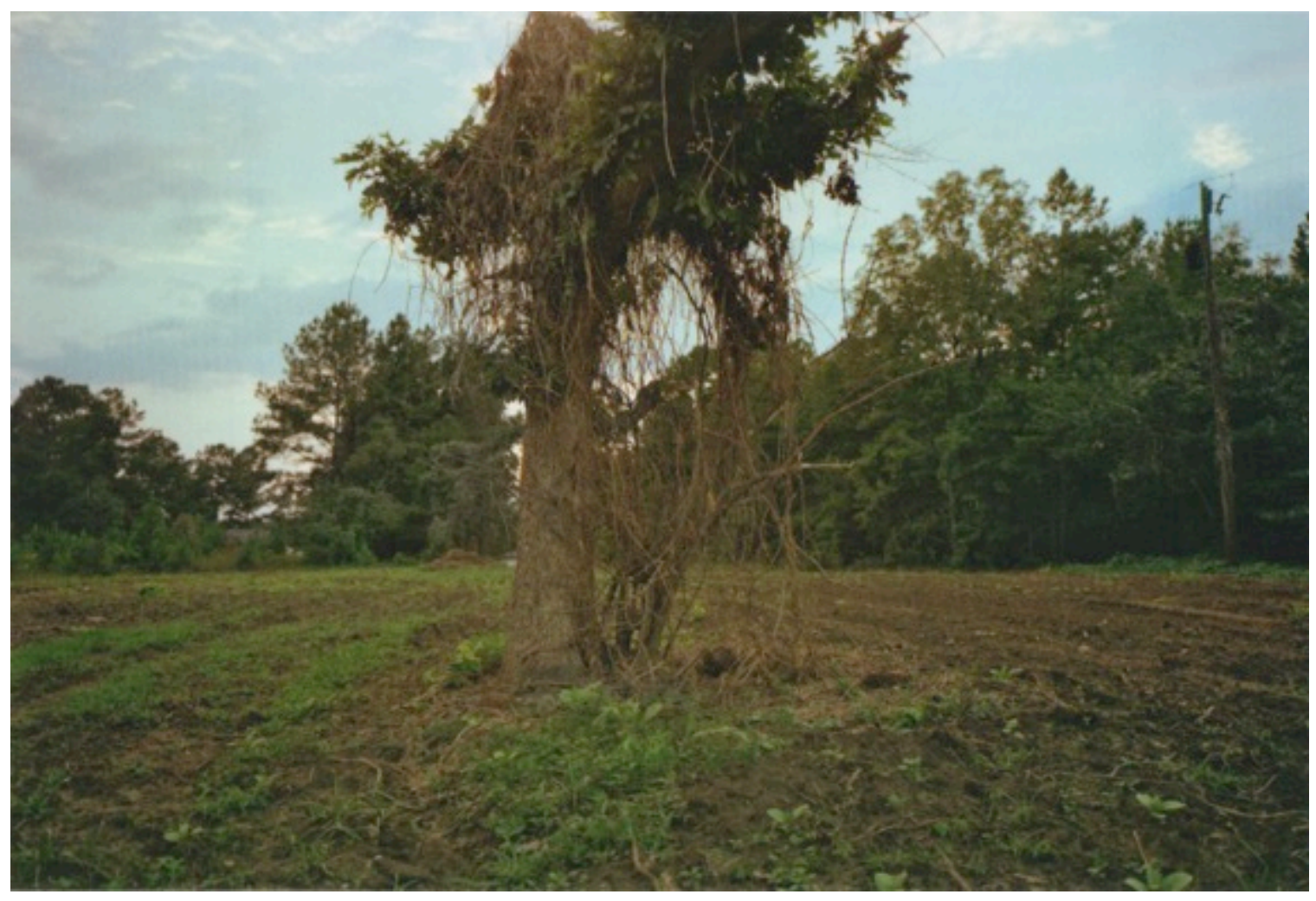

Figure 3. William Eggleston, Andersonville, 1976, Chromogenic color print, 10 1/4 x 15 in. 
reality. Such an overt engagement with the history of photography and its objects is telling, complex, and ultimately very messy. To what extent does photography approach reality and how does the tension between a photograph's subject and object play out in its relationship to concepts like truth or fiction? And how is reality defined? Questions like these are not unique to Eggleston and have dogged the relationship between photography and the world it purports to depict. They connect back to anxieties first churned up by photography's earliest iterations. While concerns with things like color or identity are often at the forefront of scholarship surrounding Eggleston's practice, they reflect and retread discussions about the extent that photographic depictions should be and can be true to their subjects. In an effort to refocus and broaden these analyses, I argue that Eggleston's photographs are less concerned with the description or documentation of what appears in front of the camera than an attestation of the photograph's own material presence within and alongside the world. Rather than a concern for the accurate documentation of the world, Eggleston's photographs point to their own existence as an adjunctive reality beside what they depict. As Thomas Weski notes, Eggleston's photographs are not snapshots, but art objects done in a "snapshot style." ${ }^{.10}$ In this way, Eggleston does more than construct particular views of an established world but a particular and parallel version of that world.

Through the placement of Eggleston's first published photographic folio in the context of late twentieth-century discussions of knowledge production and the reality of representation, I define and investigate photography's role in the viewer's experience of the perceivable world. In this way, Eggleston's "snapshot style" can be better positioned. Rather than limit the photograph to a product of the wills of its creators and users or an 
image defined solely by its content, it is productive to define it according to what Bruno Latour calls a "Thing." He explains that a Thing is a site within which objects and issues are able to gather together in multifarious and sometimes contradictory ways. ${ }^{11}$ The particular etymologies of various translations of Thing indicate something like assemblies where decisions are made by consensus that Latour describes as an interest in "matters of concern" rather than "matters of fact." ${ }^{, 12}$ Yet in this context the photograph continues to express an inherited position as something transparent, immaterial, and ultimately superseded by the content of its depictions, by the facts it is able to describe. In essence it is treated as an image at the expense of its material forms. However, the means through which photographs have come to be understood as truthful are located within concrete interactions between objects, subjects, and the structuring functions of various discourses. The habitual use of photographs for scientific, social, historical, and artistic purposes sets up persistent frameworks that allow photographs to be understood in relation to the world through both their material forms and immaterial content. Photographs also have the capacity to act upon and reconstitute reality through these same frameworks. As Barthes explains, among the messy genealogies of history and photography, reality has come to be constituted only by what can be "objectively" confirmed and proven. ${ }^{13}$ Or as Latour explains, reality is what is "common" among the many worlds in our orbit. ${ }^{14}$ The exchange of reality for photographic forms is a means of the former's literal construction. In my discussion I explore the discursive nature of photography's panoply of material forms. Weski traces Eggleston's aesthetic through earlier "“documentary-style" American photographers such as Walker Evans. ${ }^{15}$ In the sense that these conventions "consciously borrowed from inartistic source[s],"16 it is important to understand how 
such sources defined and used the photograph and how assumptions projected onto and projected from these sources might be found in the "styles" that followed after them. In this way, photographic forms can also participate as signs alongside their assumed functions as containers for signs. Keane has explored a similar idea in his studies of the ways clothing plays an active role in the making and understanding of new signs and the reassessment of old ones. ${ }^{17}$ Rather than "reduce the world to discourse and its interpretation," Keane is concerned with how signs and objects interact and how these interactions might relate to a broader "material world of consequences." ${ }^{\text {"18 }}$ Rather than an either/or critical approach, I pursue one that takes into account how issues of materiality have developed through the convergence and divergence of representation and reality within the history of photography. This is to take on what Latour calls a "stubbornly realist attitude" ${ }^{\text {19 }}$ that doesn't dismiss photography's variability but attempts to make sense of photography's often paradoxical contributions to the ways in which reality is and has been materially represented and defined. When I refer to materials and materiality, I do so beyond the aims of Karl Marx and his focus on production as the driver of value. Instead I am interested in objects as vital collaborators and contributors to meaning rather than its vessels. Jane Bennett calls this "thing-power," a power to "make things happen" or an affective agency possessed by nonhumans. ${ }^{20}$ In the context of photography, the photographic object has many functions because of its participation as a material thing. It can evoke and provoke emotions, change the course of institutions, governments, and societies. In short, the photograph has a presence.

To maintain this obstinacy my analysis likewise introduces several theoretical concepts that have played key roles in photography's historical, social, and artistic 
developments and its causal relations to viewers and the world. These include Pierre Bourdieu's and Dean MacCannell's assessments of photography's role in family and community life, Walter Benjamin's investigations of the contentious implications of photography's early manifestations, and the personal stakes of Barthes's stadium and punctum. The goal is to contextualize these approaches in accordance with the open and collaborative model of Latour's Thing in order to explore the photograph's complex and sometimes paradoxical ramifications. A last girder of support is Barthes's concept of the "reality effect." For Barthes, this idea is born out of the tendency to equate reality with "this happened" and so make historical discourse nothing more than a transparent "signifier." ${ }^{21}$ This "effect" transforms historical tools like narrative, depiction, or reportage into "privileged signifier[s] of the real. ${ }^{.22}$ Not only does the photograph tell us something about the world, so some argue and believe, but that "something" is also the truth about the world. The photograph corroborates and bears witness to this truth and forms a foundational part of consensual reality. The photograph is used as evidence in courts, as a demonstration of current events, and a form of identification for official documents. In addition, it marks and gives meaning to experiences that have great personal or social significance. Photography stakes its claim as a bearer of the real in the ease with which it is able to provide the means to authenticate and monumentalize experiences. ${ }^{23}$ The photograph offers a meeting place for these multifarious approaches within the complexities of the material object itself.

There are several "inartistic sources" through which I will draw connecting threads in order to explore how these difficulties manifest in Eggleston's photographs. Photographic archives, family photos, and travel guides will serve to frame Election Eve 
as a locus and battlefield for meaning's contestation. While Eggleston's own photographs are indebted to a more general category of amateur snapshot photograph, a broader range of photographic forms have impacted the use and reception of what is generally called "art photography." The art photograph is materially indistinguishable from photographs put to other uses. In the case of Eggleston and many of his contemporaries, the art photograph has been able to lead a separate but parallel existence to its "inartistic" counterparts made using the same cameras and film and printed and presented in the same ways. ${ }^{24}$ Because of this, the material contingencies that inform reception of both a photograph's content and its object must be understood through the uses and functions that overlap in shared forms. These coalesce in a fourth source whose implications represent Election Eve's most consequential engagement with photography's difficult relationship with reality. The mapping survey and the functions of signposts and landmarks network abstractions within the concreteness of things. To this end my initial encounters with Election Eve reflect an exploration of the book's position as a mediator of reality in the most literal sense. If it illustrates something external to itself, as in the case of Gardner's Sketch Book, then Election Eve's function as art object will accord with the traces of inartistic sources deposited within its forms and that bubble to the surface. Yet this reliance on the assumptions of appearances will prove self-defeating. Yet, failure of use is still use. To get lost in the course of using a map is as much a consequence of use as finding one's way.

Through the formal issues so embedded in his practice, the constituent materiality of Eggleston's photographs presents fertile grounds for speculation about their connections or disconnections from consensual reality and histories of use. Photographs 
generally require consideration couched within their existence as physical objects and articulation as objects of discourse in addition to the interplay between photographic and broader discursive forms. These forms, such as the archive, family photo album, travel guide, or map instill in the viewer certain ways of understanding and using photographs, ways that are reinforced through the objects and their uses. Eggleston's Election Eve, directly and indirectly, blends many of these forms together, a process that informs the use and understanding of the photographs it contains. Individual banal pictures come to form dynamic and sometimes contradictory sequences when contextualized through the various objects that are referenced by and constituted in Eggleston's practice. Yet the assumptions long built into photographs through their discursive uses (as both non-art and art objects) are also deployed by Eggleston to both extend and subvert the capacity of the photograph's assumed role as a bearer of consensual reality. In many ways, Election Eve does this by ultimately falling short of the assumed uses and functions furnished by the forms of photograph, map, and book.

Eggleston's engagement with both artistic and inartistic sources provides an immediate way into his photographs, but cracks soon appear when they fail to correspond to the consensual readings ascribed to their formal source material. What is to be made of a photograph that looks like a family or travel photo, a historical, archival, or mapping document, but fails to adhere to it in a meaningful way? Election Eve bears the traces of specific kinds of photographs that provide readymade frameworks for use and understanding. It appears to document a journey that revolves around a specific geography and a significant and established point in history. Yet appearances are misleading. Readymade frameworks prove wholly inadequate to the task. At first a 
helpful supplement, the provided map devolves into something innocuous and finally incongruous in regards to the photographs it is supposed to illuminate. It is in this sense that my investigation moves beyond simply looking at Eggleston's photographs, but attempts to utilize and define them in the ways that their forms seem to coherently mark, map, and monumentalize. If Election Eve is really a book concerned with a time and place, shouldn't it also provide the means for me to encounter the literal and discursive realities I see on its pages? In the end, such assumptions can only meet with disappointment. But as Lewis Baltz observes, even if Eggleston's photographs are "failed snapshot[s]," their failures have a considerable effect on how they exist in the world. ${ }^{25}$ 


\section{CHAPTER II}

A significant amount of time has passed since Eggleston was first given an assignment by Rolling Stone magazine to travel Plains, GA, and photograph thencandidate Jimmy Carter and his family prior to the 1976 presidential election. When he went, Carter had already departed, and so the original assignment was abandoned. Eggleston still took pictures; he detailed the things he encountered en route from his home in Memphis, TN to the rural communities of Carter's home state and county. Yet there is little of this to be gleaned from Election Eve directly. Because of the lack of exposition concerning itself, one must look to general perceptions of Eggleston's work

during that same time. Issues of identity and place in Eggleston's photographs first arose in John Szarkowski's introduction to William Eggleston's Guide, the catalog that accompanied Eggleston's major solo exhibition at the Museum of Modern Art the year before Election Eve was published. Szarkowski opens his introduction with associations between Eggleston's photographs and the various identities they seem to define. ${ }^{26}$ Eggleston's photographs can be considered reliable in the sense that they appear to conform to some reality that already exists, whether in the places and subjects he shot or his own subjectivity and identity as a person and artist. Eggleston is "Southern" on essentially the same terms as the places he photographs. Even then, it is notable the extent that this designation is engrained in his practice, at least according to his critics. 
Weski compares the Southern character of Eggleston and his pictures to the fictional yet validly real Yoknapatawpha County, Mississippi invented by author William Faulkner as the setting for many of his stories. ${ }^{27}$ In the sense that the South is already a wellestablished place, perhaps even a trope, Eggleston's photographs simply tread and retread the identity of its locations. From the outside his photographs appear to be documents of already well-known and well-worn places and identities. Yet as a wealthy descendent of a slave-owning White plantation family, these identities are also fraught with difficulty, especially in the context of breaks between North and South, rich and poor, rural and urban, or Black and White.

While the titles of Eggleston's photographs are often vague yet identifiable place names, Tina Kukielski explains that they are not always assured and can be subject to revision. ${ }^{28}$ In this sense, Eggleston loses no time introducing shades of doubt into his photographs by unpinning them from the reality to which they appear inextricably tied. Election Eve is unremarkable by these standards: it is short on narrative meaning and long on a seemingly self-aware sense of its own meandering and obtuse structure. But when considered in its particular material forms, objects like book or photographic print for example, Election Eve presents a complex set of relations firmly entrenched in contingent historical and social discourses. In his preface to Election Eve, Fonvielle picks up on these incongruities and defines the photographs as "printed tickets for a journey" through a "particular, suggestively charged geography" that would be lost to time and history as immediately as the pictures were taken. ${ }^{29}$ Of course, this assumes that at the outset Eggleston's photographs serve a documentary function and describe some real 
space or time. Yet it may be a process less about description than the constitution of these things in their own permanent, tangible, material form.

The importance of forms and materials is not foreign to Eggleston's wider oeuvre. Seven years after Election Eve was published, Baltz already saw a "preoccupation with two of [Eggleston's] most obvious features, his southernness and his debt to the aesthetic of the color snapshot." ${ }^{, 30}$ Indeed, since Eggleston's controversial MoMA exhibition, the majority of criticism seems to retread those points brought up in John Szarkowski's introduction to William Eggleston's Guide. Baltz interpreted the persistence of such controversy as a perceived failure on Eggleston's part to move beyond the "vernacular model" that he established early in his career. ${ }^{31}$ In part because an erroneous reputation as the first color photographer given a major solo exhibition, ${ }^{32}$ Eggleston remains inextricably linked to the acceptance of color photography as a legitimate extension of the medium. Yet he continues to straddle these categories of legitimate and illegitimate, a lack of resolution that manifests through the close affinity Eggleston's photographs continue to share with their counterparts in family photo albums or vacation slideshows projected on the walls of living rooms. ${ }^{33}$ Weski notes that Eggleston often showed slideshows of his photographs to relatives and acquaintances in his home in Memphis, far removed from the orbit of curators, galleries, and museums. ${ }^{34}$ Bound in somewhat ridiculous textured faux-leather, William Eggleston's Guide certainly looks the part of the family album as well. In addition its title, that recalls the still-published Michelin Guide series of restaurant and hotel reviews, is indicative of Eggleston's somewhat fraught relationship with the art public at large. ${ }^{35}$ It is as if his guide was meant to educate his audiences on things they had no idea about. 
This insistence on photography's identity and functionality as a physical object or set of objects has played a critical role in assessments of Eggleston's practice. As Donna De Salvo asserts, "a photograph is simply a mixture of cyan, magenta, and yellow dyes printed on paper. ${ }^{36}$ Beyond the capacity to depict and describe, photography also creates objects via other objects. ${ }^{37}$ Eggleston's work can be couched within discussions of photography's role as both physical and conceptual mediator, what Geoffrey Batchen generally terms "practices of intervention and manipulation" common in the production of all photographs. ${ }^{38}$ Whether in the use of the camera or the making of prints, Eggleston leans heavily on photography's mechanisms in a way that highlights their contributions to the formulation of the end product. According to John Howell, Eggleston has compared taking pictures to shooting a shotgun, an action he claims to sometimes accomplish without the use of the camera's viewfinder. ${ }^{39}$ And while he doesn't make his own prints, he has long been keenly interested in the processes, once calling a late-night visit to a photo-processing lab "one of the most exciting and unforgettable experiences as a whole—and educational for me. ${ }^{, 40}$ Eggleston's photographs are marked by what Baltz describes as the "automation" of practice and a shift to a more egalitarian approach. In light if this "democratization," success and failure are distributed differently in Eggleston's work. But where critics might consider the poles of success and failure to orbit the ways his photographs effectively deal with external issues predicated on content, Eggleston finds them located in the ways his photographs are taken, printed, or displayed. $^{41}$

On the whole, certain attitudes persist about photography's capacity for neutrality. Keane explores the ways distinctions are often made between objects and the meanings 
they carry through a contrast to the "historicity inherent to signs in their very materiality." ${ }^{42}$ Such distinctions often paint "objects as no more than illustrations of something else. ${ }^{43}$ That is, they are wholly transparent and point to already defined meaning or value outside themselves. This is a very important distinction often made between the photograph and its subject, one that Szarkowski commonly championed in his commentaries and analysis. Szarkowski considered photographs fairly neutral surfaces through and upon which other subjects, things photographed and the photographer/artist, were ultimately glimpsed. ${ }^{44}$ This is unsurprising given Szarkowski's own career as a photographer. In 1958 he produced a book of photographs called The Face of Minnesota that would serve as an authentic and appropriate souvenir for both tourists and residents on the occasion of Minnesota's centennial. While this purpose seems contradictory, Szarkowski's goal was to tie together the most compelling representations of people and geography in order to encapsulate Minnesota's identity within a single panoramic image. ${ }^{45}$

Not only a product of Szarkowski's particular critical outlook, this approach aligns with those assumptions about materiality and meaning Keane attempts to redress. Comparisons of photographs to windows or mirrors represent an effort to minimize the mediating function served by these objects. It sheds the "consequences" of the intimate associations between signs and objects produced through their dynamic relationships. ${ }^{46}$ If meaning is something independent or autonomous, interpretation simply uncovers the relationships between signs and referents rather than actively engages in the processes that enable these relations to be constructed. Because signs are often considered abstract through the arbitrary nature of their relative components, Keane attempts to 
recontexualize these relations through a focus on the means by which these relations are established in the first place. Rather than an ex post facto "communication of meanings," Keane considers how new meanings and new relations might yet be forged between signs and objects. ${ }^{47}$ Rather than ignore the material means through which meaning is constantly created, modified, and destroyed, Keane places a renewed focus on the dynamism and mutability of signs and how they are then conceptualized as meaningful and intelligible. In the context of photographic books, the complexity of relations between viewers, objects, signs, and discourses provides them the means to inform meaning rather than just contain, record, or report. The photograph does not close off these dynamics at the instant of capture or printing, but remains open to further material and immaterial transformations as it passes into new and sometimes divergent contexts. As Barthes defines it, a discourse is not a set of statements but the description of such statements. ${ }^{48}$ On their own, statements (including photographs) have little value. Instead they must be inserted into discourse, affirmed to the world through their transformation into something legible.

As Barthes explains, refrains of "the thing has been there" and "this happened" are often offered as the evidence of reality. ${ }^{49}$ The photograph's relationship to reality is not to make the latter visible, but a proclamation that "the event represented has really taken place." ${ }^{50}$ While Eggleston's Election Eve is simultaneously a book, a set of color photographs, and a set of signs, the complexity of its materiality is a function of the expectation that its forms bear witness to what they depict. Each form, including the book, the photograph, and the material sign, must confirm and affirm reality according to the contingent semiotic ideologies that determine how signs generally operate. ${ }^{51}$ In a 
sense, Election Eve appears useful and meaningful because interactions between object and sign are guided by ideologies also located within its forms. This allows the viewer to ask what truth can and has been read through and embodied in them. If an image can function as a text, what then are the implications of a book of photographs whose various forms are legible in the same way? How signs are understood as signs can have implications on the way objects are expected to conform to these ideologies as well.

The object therefore plays a vital role in the process through which ideologies or embedded "cultural totalit[ies]" allow for new signs to be generated. ${ }^{52}$ Not only is Election Eve signified by its formal resemblance to a discrete object like Gardner's Sketch Book, the role this resemblance plays in a larger construction of reality also leaves it open to future meanings. The book form's signifying function "entails sociability, struggle, historicity, and contingency" for the future in addition to the past and present. ${ }^{53}$ The semiotic ideologies embedded in objects can continue to inform the translation of fragments into larger established bodies like History or Photography. ${ }^{54}$ Because of the importance of forms to the development of such discourses, they are intertwined. In fact, Barthes proclaims that History and Photography were invented at almost the same time, a paradoxical yet symbiotic link embedded in the photograph itself. ${ }^{55}$ This relationship is unabashedly exploited in Gardner's Sketch Book. A photograph like A Harvest of Death (1863) (Figure 4) is predicated on an accompanying text that assures the viewer that its spectacle of corpses serves a broader purpose. The text claims that "Such a picture conveys a useful moral" and ties the minutia of depiction to a method of reportage that draws a direct parallel between exposition and image. ${ }^{56}$ In one sweep, both are conceptualized as bearers of truth. The more obviously staged A Burial Party, Cold 


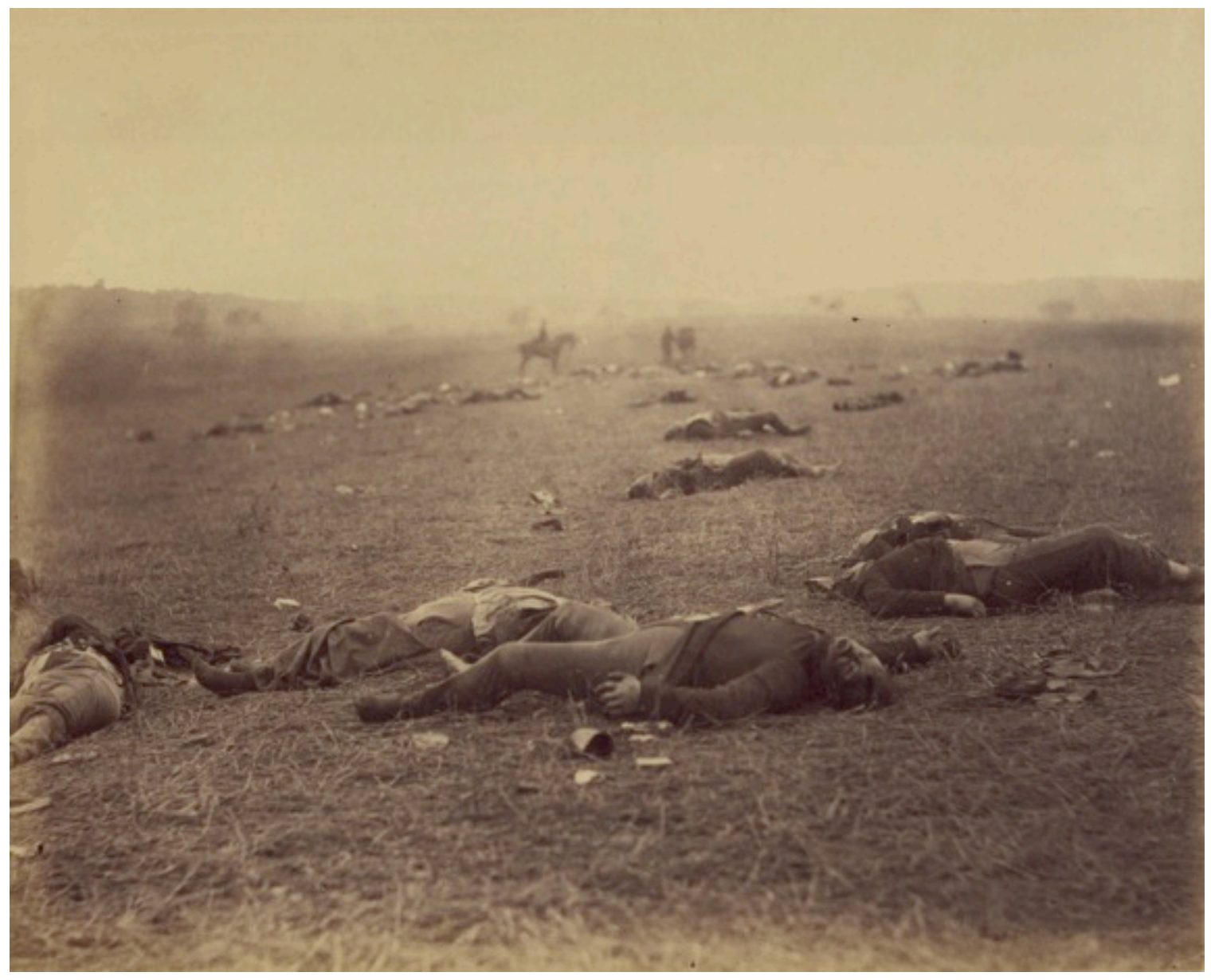

Figure 4. Timothy H. O’Sullivan, A Harvest of Death, Gettysburg, Pennsylvania, 1863. Albumen silver print from glass negative, 7 x 8 15/16 in. 
Harbor, Virginia (1865) (Figure 5) is provided a similar narrative interpretation.

Causality is drawn out of the faces of the living and the dead in the photograph's desolate landscape by the simultaneous insertion of text and image into a larger historical narrative concerning culpability for the destruction wrought by the Civil War. In both instances the paradox rests in the fact that each text and image is offered as proof for the other.

While Eggleston's photographs are an obvious contrast in content and subject matter, they respond to a similar structural connection between image and description. Texts are not provided, unlike Gardner's Sketch Book, and so the structure is visually withheld. The viewer is left only traces and contingencies with which to draw conclusions. In photographs such as south edge of Plains (Figure 6) and Mississippi (Figure 7) there is no gore, but detritus is similarly scattered about the natural landscape. Yet unlike in Gardner's Sketch Book, the book makes no attempt to historicize or contextualize. Instead, Empty beer cans, a faded and fallen billboard, and the rusted red hulk of some piece of abandoned construction machinery, littered among high weeds, inherit their statuses as previously demarcated signs and previously established meanings. The reiteration of identities pulls this divergent content together. Discarded cans and rusted metal serve the same signifying function as bleached skulls and bloated corpses. In the viewer's rush towards significance, Eggleston's photographs benefit from the means by which the genealogies of History and Photography have already been established. By the token of formal resemblance, both in organization and the more subtle unities of their landscapes, Gardner's Sketch Book provides the photographs of Election Eve a manual to 


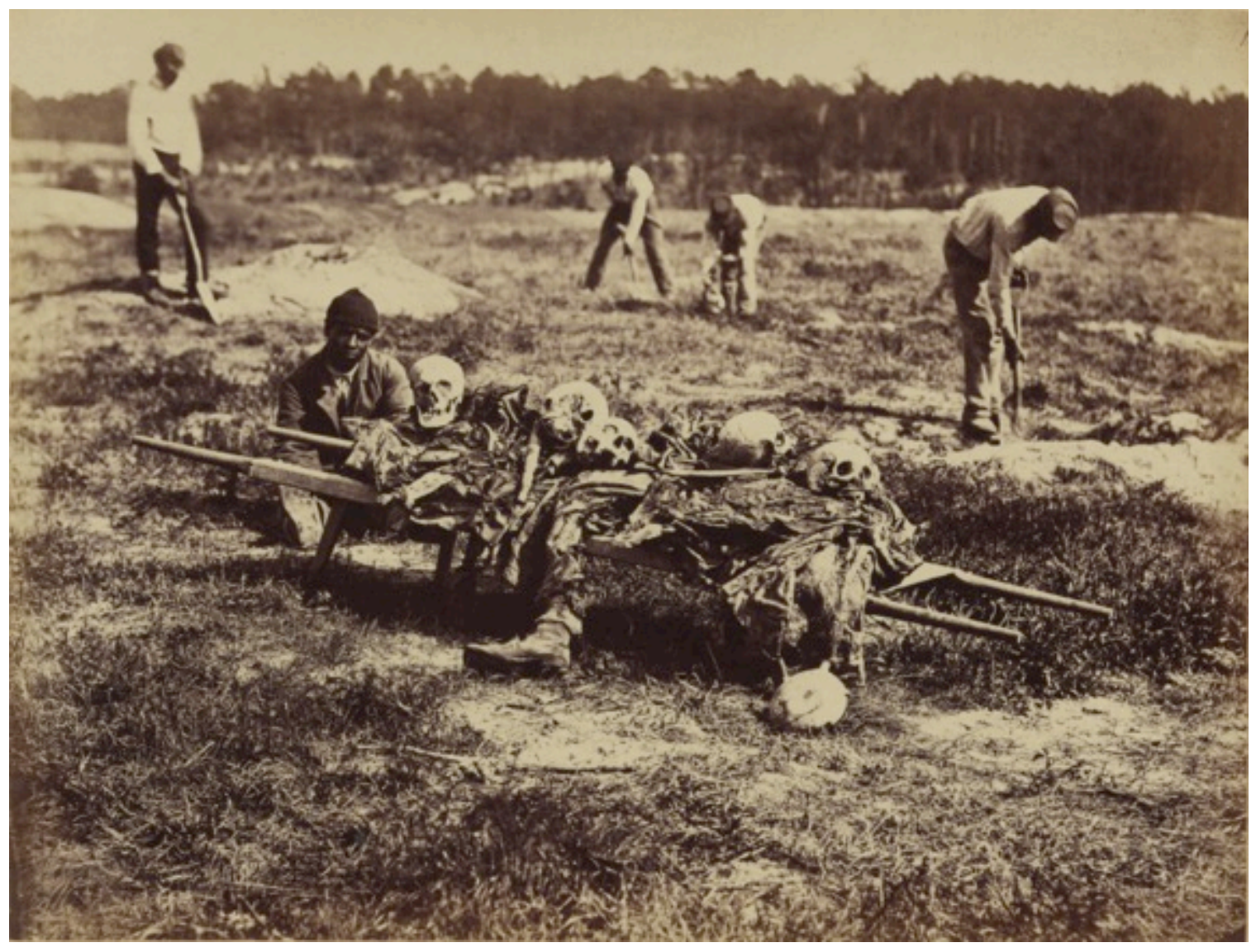

Figure 5. John Reekie, A Burial Party, Cold Harbor, Virginia, 1865. Albumen silver print from glass negative, 7 × 8 15/16 in. 


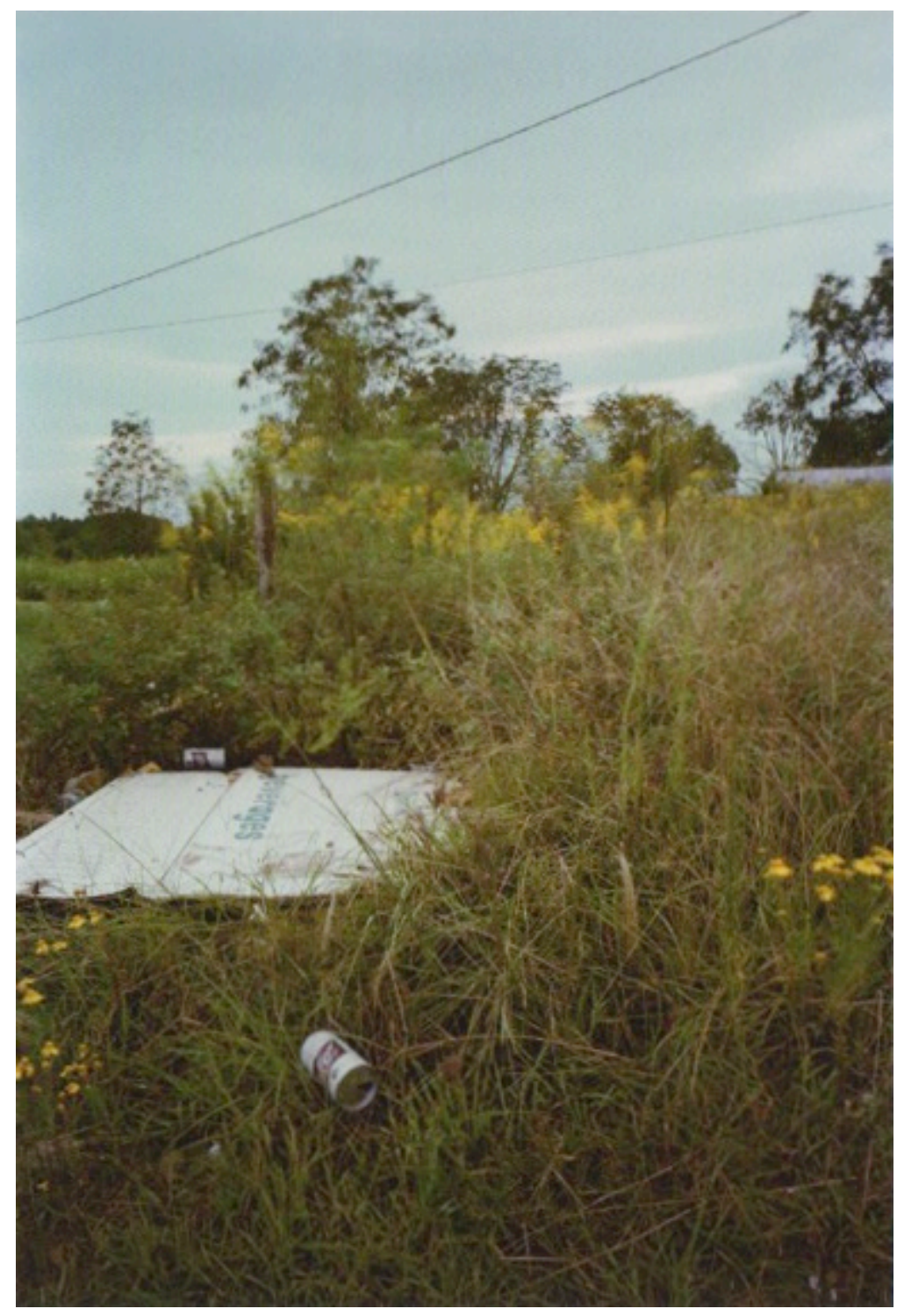

Figure 6. William Eggleston, south edge of Plains, 1976, Chromogenic color print, $15 \mathrm{x}$ $101 / 4$ in. 


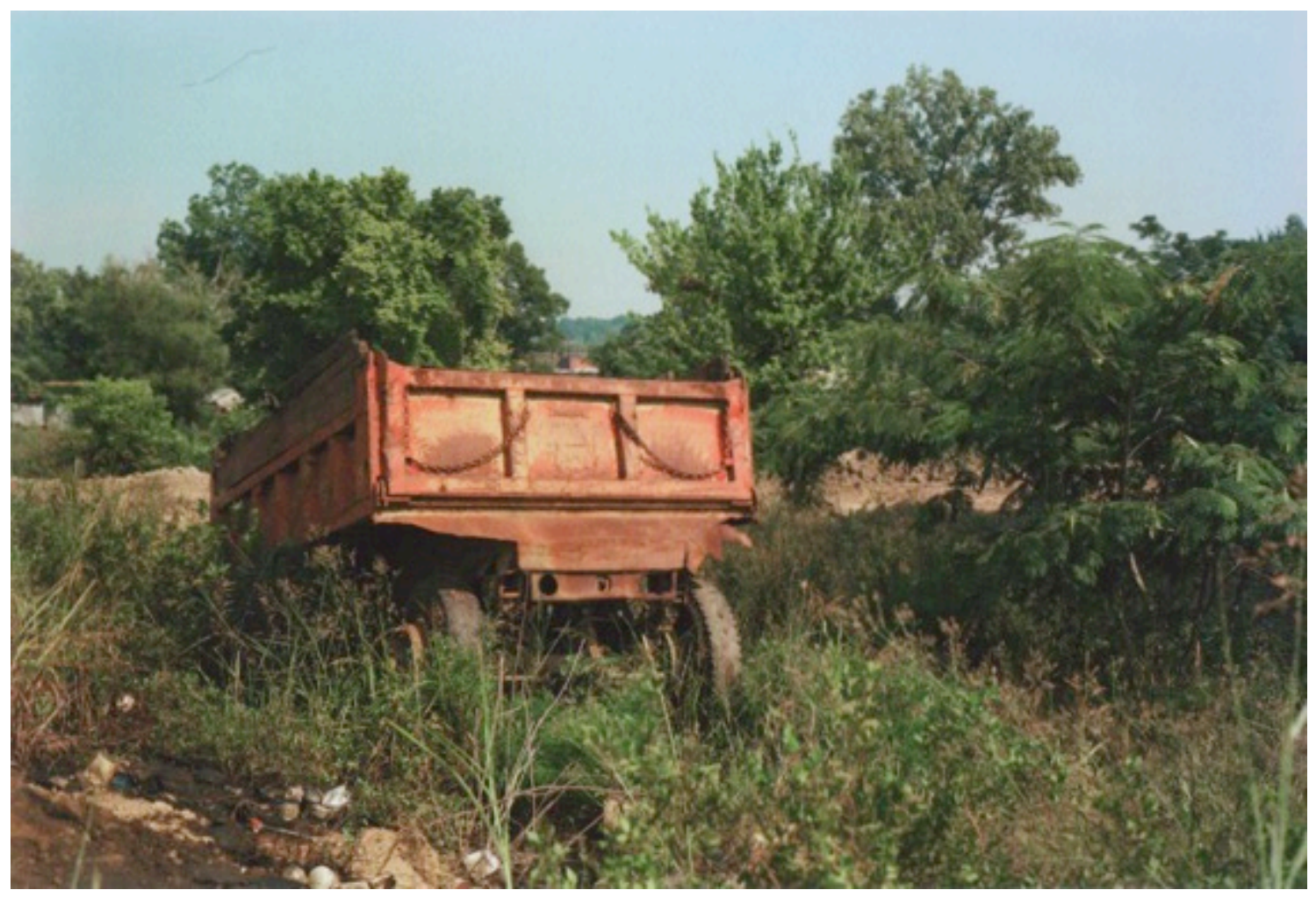

Figure 7. William Eggleston, Mississippi, 1976, Chromogenic color print, $101 / 4$ x 15 in. 
"make them talk," as Latour puts it, in order to procure their use in the production of meaning. ${ }^{57}$

Perhaps this is one the reasons Eggleston—apart from his identity as a Southerner, Southern photographer, and color film practitioner-continues to be associated with attempts to define the identities of the places he photographs. Encounters with his photographs entail a functional shift from "describing life" ${ }^{58}$ to its constitution. The photograph solicits the transformation of history into a legible material form. That Eggleston has in the past asserted his photographs are modeled after the Confederate flag might reveal a broader association between objects like the photograph or book and assumptions about the active role they play in the construction of reality. ${ }^{59}$ Eggleston's personal stake in his photographed landscapes folds additional ideological play into their meaning as signs. Eggleston's book invites its own insertion into broader discourses on events and issues like remembrance, mourning, or conflicts between regional and national identities. In addition, such invitations lie beyond the legibility furnished by a limited comparison to something like Gardner's Sketch Book. Presupposed historical implications attributed to Election Eve consequently translate its depicted landscapes and people into those destroyed by the sins of slavery and treason. Election Eve can read like the continued aftermath of the war Gardner presents, due in no small part to this embedded function, formal resemblance, and the interventions of a shared discourse.

Because photographs are things in the world, it is necessary to understand the ways photographs interact with other objects and subjects and the consequences of such interactions. A photograph, whether printed on paper or displayed on a screen, is mediated by some physical medium. This compounds the role that photography has 
played and continues to play in the creation, description, and preservation of knowledge in various fields. Such is the photograph's "archival function" that Michel Foucault describes as

the first the law of what can be said, the system that governs the appearance of statements as unique events. But the archive is also that which determines that all these things said do not accumulate endlessly in an amorphous mass, nor are they inscribed in an unbroken linearity, nor do they disappear at the mercy of chance external accidents; but they are grouped together in distinct figures, composed together in accordance with multiple relations, maintained or blurred in accordance with specific regularities. ${ }^{60}$

Here, photography is both the "language" and "corpus" of documentation, the body and the way it is described. ${ }^{61}$ Hardly an action of random or thoughtless collection, the photographic archive exerts its own will on the external world through its status as a constituent of reality. This photographic will, in the words of Fred Ritchin, "filters the world according to its own characteristics" and connects the archive directly to reality. ${ }^{62}$

In the way that reality flows out of the archive, photographic practice likewise shapes the way the world appears and how it views itself. In 1927, Siegfried Kracauer proclaimed that the "world has taken on a "photographic face." The world was not merely organized (after the fact) by the formal and stylistic characteristics that marked photographs. Instead it was molded in anticipation of its appearance as an image in masses of photographs. ${ }^{63}$ Indeed, the dramatic proliferation of photographs and archives in the late nineteenth and early twentieth centuries coincided with new methods for the collection, organization, and control of knowledge, especially in regards to the 
"scientific" study of human bodies. As Allan Sekula demonstrates, the deployment of large-scale photographic archives during the nineteenth century through the efforts of Alphonse Bertillon in France and Francis Galton in England was a means to control and regulate bodies within a social framework via to the photographic representation and classification of those same bodies. ${ }^{64}$ Photographic archives amassed and proliferated alongside new discourses such as physiognomy and criminal typology ${ }^{65}$ and aided in the development of what John Tagg defines as "prescriptive" political, social, and cultural institutions ${ }^{66}$ The archive as an authoritative unit "authenticated the truth claims made for individual photographs," claims that were then deployed in large-scale law enforcement or medical operations under the guise of public health and safety. ${ }^{67}$ That the most extensive photographic archives were maintained by police departments and mental and public health institutions reiterates the "shadowy presence" of social control that Sekula argues still haunts the connections between photographs, reality, and the truth of depiction. ${ }^{68}$

The claimed neutrality of certain kinds of photographs, such as those that belong to Evans's “"documentary style,"”,69 also implies a veracity and trustworthiness drawn from association with and resemblance to the archive and its strategies. But more than just strategies expressed in the style and content of its photographs, this veracity is also informed by the ways archives are physically structured and organized. Be it artistic, private, or government-sponsored projects bent on the preservation (in images) of fading forms of regional architecture or attempts to record the histories of vulnerable people and places ${ }^{70}$ the truth claim of "that happened" owes much to the systematic structure furnished by the archive. The great mass of photography is better able to bend reality to 
itself than the individual photograph. Even then, as fragments of larger bodies individual photographs are still often perceived of as, according Ritchin, “"windows' on the world." ${ }^{, 71}$ Yet windows are projections onto reality rather than of reality, projections whose intention is to generate truth through the assembly of images. While this might be a "transcendental immortality, a higher, less finite, reality,",72 it is a reality nonetheless. While photographers like Eugène Atget looked through the camera in order to create masses of fragments that could be later combined to make more coherent and complete images of the things they captured, Molly Nesbit argues that the world likewise reflexively remade itself into a form better able to accommodate its continued transformation. ${ }^{73}$

Beyond its role in the constitution of reality are the archive's more subtle functions of reference, remembrance and memorialization. Apart from but not altogether severed from their institutional counterparts are those methods employed for social or artistic purposes. Such uses represented one of the first ways the photograph was conceptualized as something more than a base object. Pierre Bourdieu calls this its existence as "pure sign" whose meaning is derived from its social uses. ${ }^{74}$ Yet the worth of the photograph and its value as a sign can also be traced to its initial value as an object. Walter Benjamin characterized the photograph's earliest conceptualizations in the nineteenth century as both heirloom and "technical adjunct." ${ }^{, 75}$ The earliest photographs were not collected because of some inherent artistic value but were objects whose realness was considered co-equal to that of their depictions. While many admired photography's possibilities and technological capacities, others feared and scorned them, a reaction that belied a belief that photographs were capable of perfectly encompassing 
and therefore acting in lieu of reality. In essence, photography's uncanny representations demonstrated the potential to disappropriate God's or Nature's sole authority in creation. ${ }^{76}$ Early photographic reproductions were sometimes considered semi-conscious agents as well as images. Quoted by Benjamin, the nineteenth century daguerreotypist Karl Dauthendey expresses such a sentiment: "We were abashed by the distinctness of these human images, and believed that the little tiny faces in the picture could see us, so powerfully was everyone affected by the unaccustomed clarity and the unaccustomed fidelity to nature of the first daguerreotypes., ${ }^{, 77}$

Since its inception, photographic technology has enabled both reproductions of and additions to reality, not just as images but also discrete things in the world. In its role as technical adjunct, Benjamin describes how photographs functioned much like live models. As aids to painting they represented real objects with all their requisite presence in the world. But these aids did not remain subservient to painting, drawing, or other artistic reproductions. Instead, photography became more and more distinct as a separate medium. Benjamin notes that this is the reason nineteenth century painter David Octavious Hill is hardly remembered for his paintings. Instead, the photographic studies he produced to aid his work as a painter took on their own status as art objects. ${ }^{78}$ Even though they were not intended to be used or understood as anything but references for his painted subjects, the value of Hill's photographs was borne out by those "tiny spark[s] of contingency" located in the means by which the depicted figures and objects were treated as if they were real. ${ }^{79}$ This was not unlike the exponential proliferation of the photographic portrait and subsequent decline of its painted counterpart. 
In a more contemporary instance, the career of photographer William Christenberry, Eggleston's friend and colleague, began with color snapshots taken with a small Kodak Brownie camera that developed from neutral references to fully endowed art objects. These photographs depict the somewhat nondescript buildings and landmarks in Christenberry's native Hale County, AL. Though hardly bearing the "unaccustomed clarity" (at least in a technical sense) described by Dauthendey, they quickly became the sole focus of his artistic practice. Christenberry returned to Alabama year after year to photograph the same sites and structures in order to capture the change and decay wrought by time.$^{80}$ This "archival" project differs significantly from that of Evans and other documentary-style photographers whose artistic inclinations were folded into broader purportedly neutral or moral aims. Christenberry's focus was the capture and archive of things whose significance was a confluence of the personal and artistic. ${ }^{81}$ Perhaps it is unsurprising that he began his career as a photographer with the same kind of Brownie camera he was once gifted as a child. Often an integral part of the family experience, photography has long played an important role in the expression and constitution of social ties, serving what Bourdieu calls a "solemnizing and immortalizing" function for the various moments and events important to family and community life. ${ }^{82}$ Additionally, Bourdieu explains that the "family album expresses the essence of social memory, ${ }^{\prime 83}$ both the general method of documentation and the form of the specifics of family life. The occasions of marriages, births, deaths, and summer vacations are imminently photographable and expected to be so. Taken together, photographs of such things form a coherent iteration of reality that likewise reinforces the assumption that the experience of time is necessarily linear or chronological. Through 
photographer-antihero Antonio Paraggi, Italo Calvino offered this insight: "One of the first instincts of parents, after they have brought a child into the world, is to photograph it... The photograph album remains the only place where all these fleeting perfections are saved and juxtaposed, each aspiring to an incomparable absoluteness of its own. ${ }^{, 84}$ In its sense of totality, the family archive makes memory something real and graspable, it "give[s] a body to recollection... substitute[s] it for the present. ${ }^{, 85}$ Not only is remembrance ceded to the family album, it also becomes the form of family life's significance. The social concept of family flife is legible only when it is is marked by the linear succession of signposts that take the form of photographs within the ubiquitous family photo album. Taking and sharing these pictures with others acts to both establish and authenticate the reality of the family.

Much like Eggleston, Christenberry's practice concerns the consequential signifying ties between the image and its expression. Christenberry's photographic practice is bookended by diverse relationships with other media. While he used his earliest Brownie snapshots as color references for paintings, the photographs of the buildings to which he continually returned later became references for three-dimensional maquettes. As these buildings became his central focus Christenberry took up more professional $35 \mathrm{~mm}$ and large format cameras. He strictly structured and regulated the character of his photographs, such as the repetition of elevation views and specific angles, in order to foster a sense of cohesion between photographs whose capture spanned decades in some cases. As he returned every year to Hale County, Christenberry photographed the same select set of structures from the same or nearly the same vantage points. Displayed together, such as four photographs of Building with False Brick Siding, 
Warsaw, Alabama (1982-94) (Figure 8), the bodies amassed by Christenberry exists as total experiences of something real in terms of the past, present, and potential future. Shot in a style not unlike the architectural surveys conducted by Farm Security Administration photographers during the 1930s, the sequence shows exactly what the title suggests, a brown two-story building with a gabled roof that hangs over a yawning cavernous recess where a door once was. Three irregularly placed kudzu-thronged columns support the roof and the building sits in front of what is at the outset a gravel road.

While these characteristics remain relatively static, the building succumbs to the changes produced by the passage of time. As this particular sequence progresses the building is engulfed by more and more weeds, vines, and kudzu. Finally, only a hint of its roof is visible in this massive tangle of vegetation. Every inch of space, including the road in front, is swallowed up by the encroachment of nature. While this procession of time is constituted by the procession from one photograph to the next, the sequence's entirety is likewise accessible in the same panoramic moment. As Justo Navarro explains, it is in this sense that Christenberry's photographic practice is concerned with time as an effect rather than as a set of discrete measurable moments. ${ }^{86}$ Due in part to the systematic nature of his approach, ${ }^{87}$ Christenberry deploys the archive's coherence to mask the immense gaps of time between his photographs. The decay and eventual destruction of this particular building is cast as a single continuous event outside time's normal directional or chronological configuration. Yet the total effect is far removed from its own strictly quantified depiction even while the photographs are accompanied by pertinent documentary information like date and location. Instead, legibility hinges directly on the experience of the photographs themselves, first in Christenberry's 

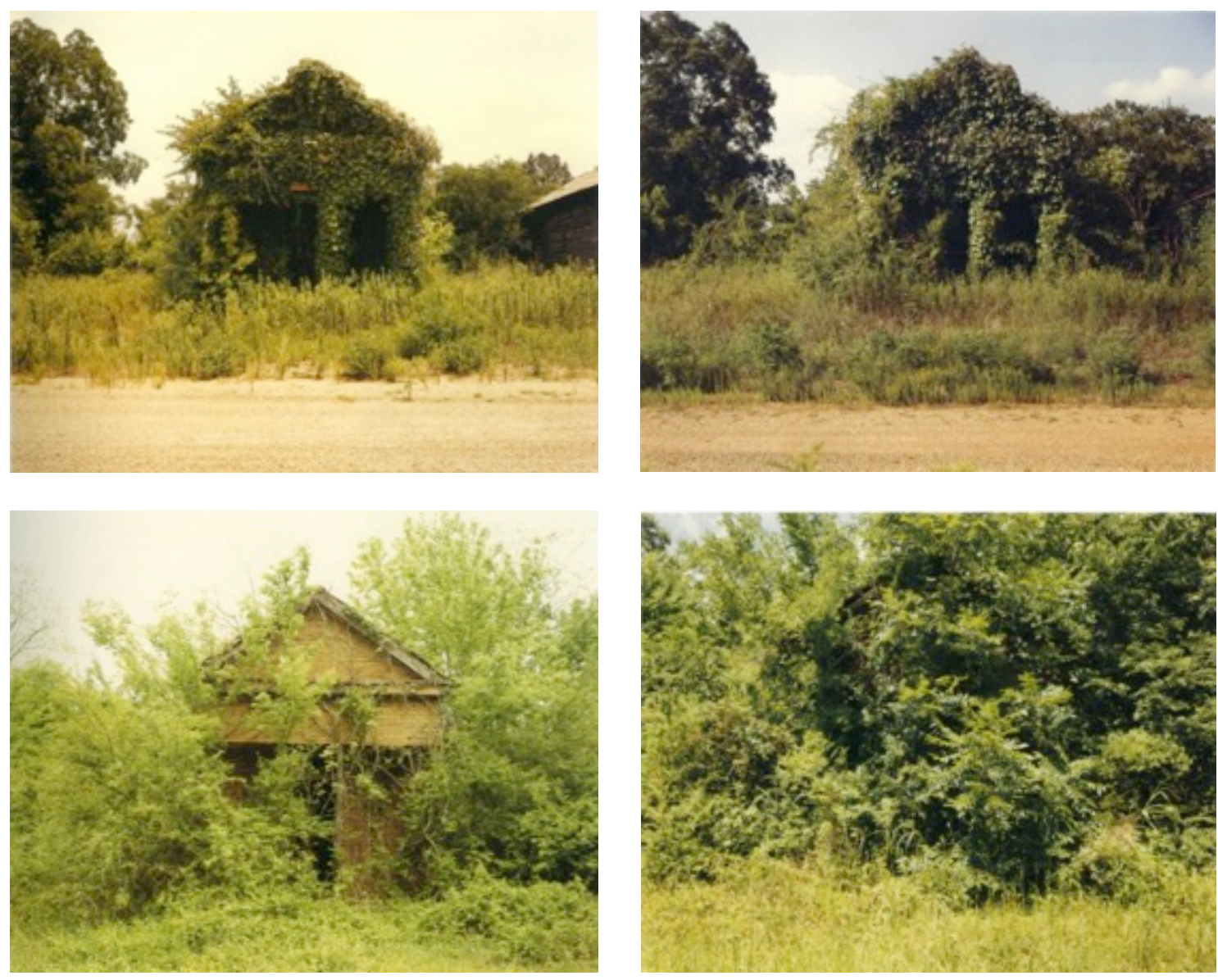

Figure 8. Left to Right: William Christenberry, Building with False Brick Siding,

Warsaw, Alabama, 1982, Dye-transfer print, 20 x 24 in.

William Christenberry, Building with False Brick Siding, Warsaw, Alabama, 1984, Dyetransfer print, $20 \times 24$ in.

William Christenberry, Building with False Brick Siding, Warsaw, Alabama, 1991, Dyetransfer print, $20 \times 24$ in.

William Christenberry, Building with False Brick Siding, Warsaw, Alabama, 1994, Dyetransfer print, $20 \times 24$ in. 
personal attachment to the place and then transformed into something meaningful for the viewer.

Another side of this object or material focused experience of time is the photographs of Eve Sonneman. Like both Christenberry and Eggleston, Sonneman became a practitioner of color film during the 1970s after previously working in black and white. She produced hundreds of diptychs that featured photographs whose paired subjects were captured at relatively different times and vantage points. While she directly references the strategy of photographer Henri Cartier-Bresson typified by his 1952 book The Decisive Moment, Sonneman buttresses Cartier-Bresson's mystified photographic "moment" between shots of its before and after. Sonneman draws the moment between two physical poles rather than directly visualize it. What is not shown is assumed to be her actual subject. Sonneman represents this by the literal gap between the diptych's two photographs. Contextualized as the unseen element of each pair, the two photographs in turn make visible then shed the presumed autonomy of the individual instant in order reroute and expand its definition. In one such diptych, Landscape/Cloud, New Mexico (1978) (Figure 9), the left and right photographs show a blurred desert, probably shot from a moving vehicle. The left is a fairly straightforward sandy brown plain dotted with scrub that stretches back towards several rocky outcrops under a clear blue sky. In the right photograph smudges of white clouds hang above the desert as it recedes towards a line of darkish mountains. A blurred but recognizable road sign juts into the center of the frame and cuts both clouds and photograph into two parts. If understood as contextual documents, these photographs indicate that there is something between them, probably more of the variable terrain and sky along whatever road or highway Sonneman travelled. 

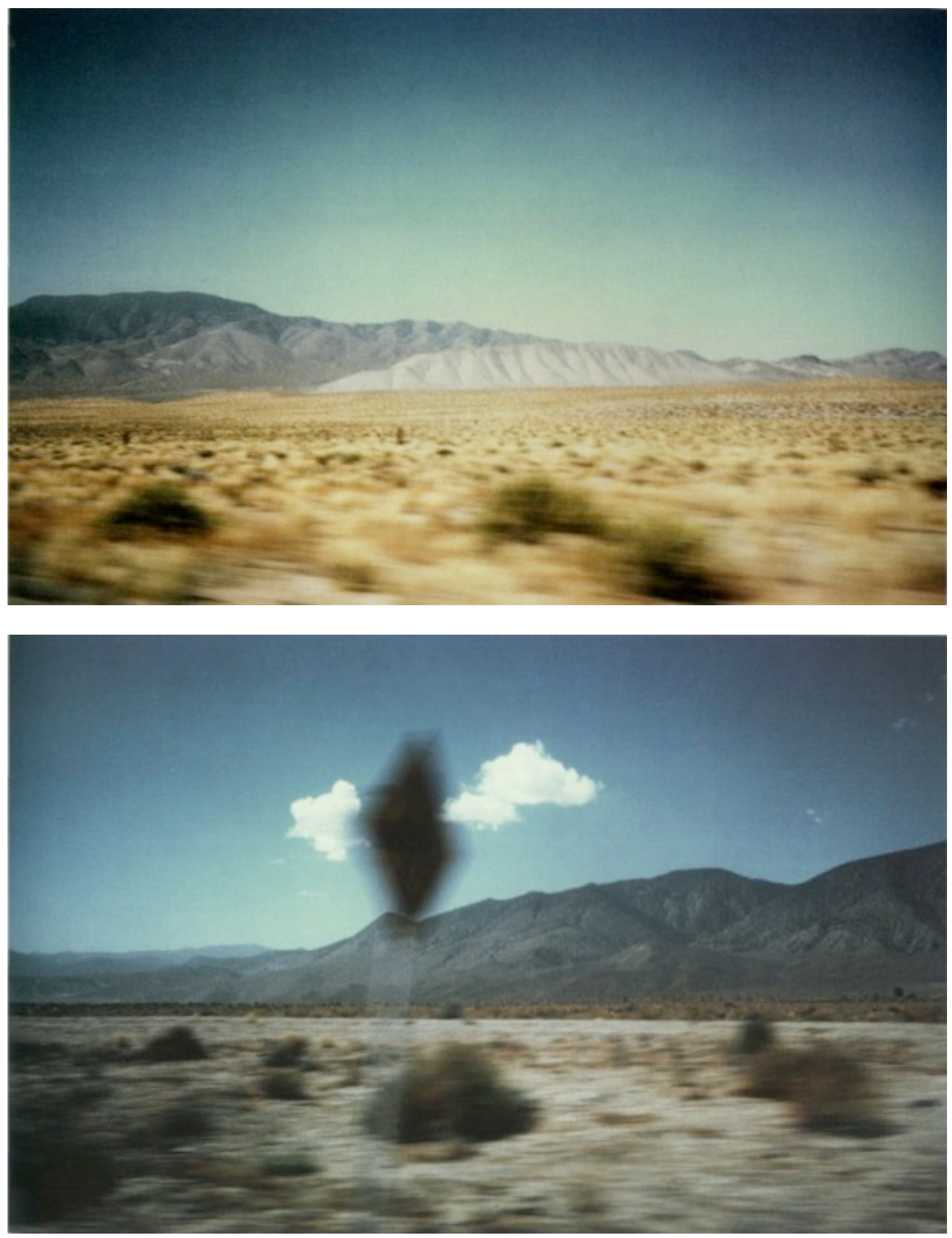

Figure 9. Eve Sonneman, Landscape/Cloud, New Mexico, 1978, Two Cibachrome prints, each $8 \times 10$ in. 
The photographic event is palpable and kinetic by virtue of its suggestive composition even with the "decisive moment" visually absent.

But this is exactly the problem. Sonneman's diptych may not actually be sequential, at least not in a chronological sense. The admixture of juxtaposition, relative similarity of content, and the assumption that the photographs follow the flow of time provide an easy roadmap for presumed meaning. ${ }^{88}$ The presumption that these photographs represent the opposite ends of some specific and ultimately consequential point is initially invisible in its appearance and operation. But when exposed, it suffers very little scrutiny before it crumbles. The gap in time and place between these two photographs of desert landscapes could be miniscule or immense, backwards or forwards, but there is just enough information and just enough of reality's affects and effects dangled in front of the viewer that such inconsistencies bubble to the surface unresolved. Another diptych addresses a similar dilemma. In The Instant and the Moment, Greece (1977) (Figure 10), Sonneman provides another set of photographs that at the outset seem connected by time and space. More akin to a tourist's picture, the left shows the Parthenon in Athens under an overcast sky. Visitors mill about outside the Parthenon and in the rubble-strewn field that surrounds it. The right photograph is even more banal. It features a ticket office or possibly a bus platform. Police, clerks, and nondescript figures walk up and down a white concrete slab in front of the building or duck in and out of its doorways. The slab and building fill the entire frame except for a small patch of sky in the upper right corner that shows a fragment of overcast grey much like the sky in the previous shot. 

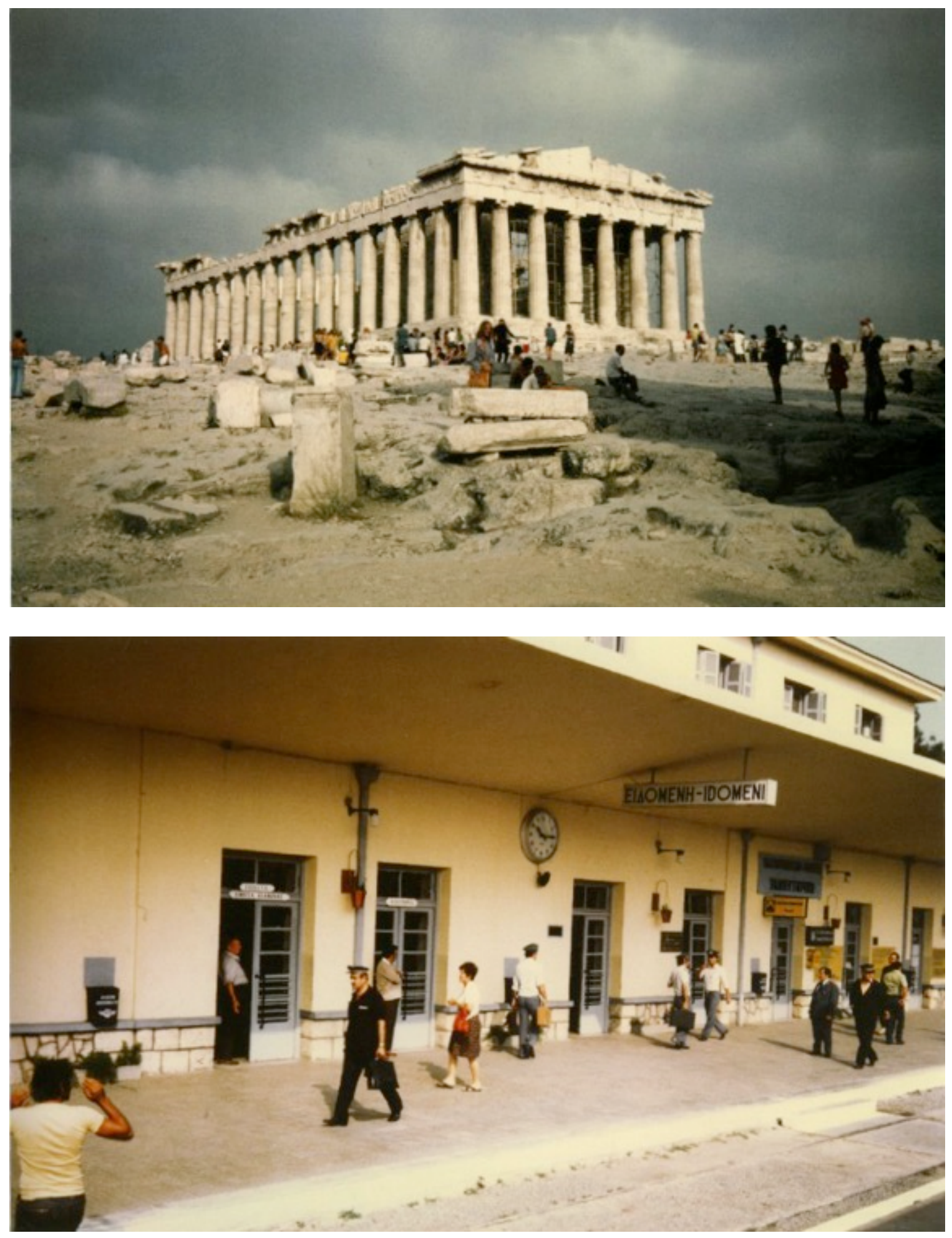

Figure 10. Eve Sonneman, The Instant and the Moment, Greece, 1977, Two Cibachrome prints, each $8 \times 10$ in. 
Again, the two photographs seem to belong to the same general place and time. This is evidenced by the similar lighting conditions, weather, figures, and the fact that the two photographs are shot at nearly the same angle. Finally, the two photographs are physically juxtaposed in a seemingly consequential manner. Even more than Landscape/Cloud, New Mexico, Sonneman's title provides an overt reference to CartierBresson's moment, an effect that initially draws the two images into closer concert. But like Landscape/Cloud, New Mexico, this contextual relationship seems more fictive the more it is scrutinized. Especially bothersome is the juxtaposition's lack of formal logic. There is a touristic feel to the content; the Parthenon is a popular well-photographed destination yet it comes before an image that implies the travel to get to such a location. The photograph of the ticket office or bus platform is denied an anticipatory narrative buildup simply because it is second in the sequence. This disconnect shifts the focus to the missing piece between the photographs and amplifies its mystery. How can a moment be decisive if it remains hidden and no clues point towards its identity? Sonneman's subtle play with the expectations of forms reveals a project that questions the assumed relationship between a photograph and the truthfulness of both its depiction and presentation. As Tiffany Bell explains, Sonneman's interest in "how things are put together" translates the physical juxtapositions of her photographs into the passage time. ${ }^{89}$ This enables and encourages the viewer to experience these things in the same way. It allows her diptychs to project reality's appearance and veracity but in a way that also calls attention to the gaps ultimately created by their artificiality. As Sally Eauclaire points out, these objects are more invested in their relationships to each other and the viewer rather than to content they display. ${ }^{90}$ While they initially appear to gesture 
towards something external and abstract, the juxtaposition of the photographs makes them spatial and concrete. Much like the photograph's frame, the limits of the interactions between objects and viewers are literal borders that mark off and enclose a physical space.

As with Christenberry's arranged progressions, time and as a consequence reality are recast as an effect traced in physical manifestation. Sonneman represents this by literally binding individual photographic moments together into singular coherent (and ultimately incoherent) events. As Barthes claims in his 1980 book Camera Lucida, a photograph is connected to what it depicts in two ways: it affirms that something was in fact in front of the camera when the picture was taken and this contingent connection to the past guarantees the eventuality of death. ${ }^{91}$ Even then, the photograph is itself incapable of providing some definitive link between an eternal past and an eternal present. ${ }^{92}$ The coherence glimpsed in the photographs of Christenberry and Sonneman is ultimately a literal and conceptual construction. Presented in such a way to the viewer, it also leaves behind clues that attest to its artificiality. Here reality's trace is a deposit, disconnected from its source in the same way that the photograph remains disconnected from what it depicts. The decisive moment is made legible in much the same way. Only after a picture is made does it pass into a discourse that confers on it its elevated status. The presentation of time's monumentality and immortality is merely a physical manifestation, a finite representation that likewise suffers from the effects of change and decay ${ }^{93}$ Outside discourse and its signifying function, the photograph can only witness to itself as a bounded and limited object or set of objects. Content, though it is drawn out from time's apparent procession, is neither true nor false but simply a part of the 
photograph's broader material existence. As Ritchin wonders, "to what extent is each photograph fictional or nonfictional or do these terms even apply?"94 Or did they ever apply? It seems that the only "real" thing the photograph can provide is its own body considered on its own terms.

Rather than time's direct experience, these photographs ultimately represent nothing more than the assembled traces of its effects. Yet they are embedded in the same kind of material form, a form that corresponds to a photograph's material presence in the world. The exchange of a representation of the past for the experience of the present takes place through the negotiations viewers are required to make when faced with photographs in their various forms and contexts. While representations are certainly not the same thing as their sources, the photographic image often plays the role of its depiction's surrogate. This is especially pertinent to images of things changed or lost. Rather than simply or transparently represent, the photograph constructs and constitutes its own reality through its ability to be cited and therefore conceptualized as knowledge. ${ }^{95}$ Barthes posits that "the same century invented both History and Photography," 96 and these discourse can be understood through the overlap of their effects. By extension consensual reality is rooted in those things, material and immaterial, that can be legibly systematized according to discourse and its forms. A sign is constituted through the artificial coupling of its signifier and signified; a sign's connection to its referent is likewise fabricated. But as part of the legible world, the photograph — a sign that is also an object — configures and asserts its own modes of reality and subjectivity as a "product of processes and materials... subject to time's progression. ${ }^{, 97}$ In this sense, photography shares an affinity with the perceivable world because it is materially indistinguishable from it. Made of the 
same stuff, it stakes a claim that elevates and shrouds its constructed face. It is neither true nor false, but real. 


\section{CHAPTER III}

The exclamations of "That's me!" or "That's you!" or "That's it!" that often accompanies looking at photographs ${ }^{98}$ are not quite misrecognitions but assertions that photographs can stand in for reality. Or, they can at least occupy the same position relative to the viewer. In the sense that photographs are often used as documents, they are deployed as surrogates that activate the re-experience of their depictions in both visual and concrete ways. Among pictures in family photo albums of relatives, pets, and family and holiday celebrations are images of vacations. The purpose of these touristic photographs is to not to record the elements of travel, the people, locales, and objects, but to concretize what Dean MacCannell terms "cultural experiences." 99 According to MacCannell, these kinds of experiences require some kind of mediator to bind the spectacle and spectator together in a meaningful way, a mediator whose function must also be transparent and neutral. ${ }^{100}$ While the photograph often purports to only document and record, it is actually the means by which an experience becomes a real thing, the

locus though which it is transmuted into a material and therefore meaningful form. ${ }^{101}$

The tourist photograph is also a means by which the abstract action of memory is materialized and integrated into social reality. When the photograph's individual representations conjoin into more complex configurations they provide a "more complete" or "truer" version of experience. The linear structure of things like photo 
albums and slideshows approximates the chronologic passage of time. This lets them share in reality's appearance and effect. ${ }^{102}$ By a similar token, such forms can also serve as material manifestations of memory. Connections can be easily drawn between the operations of memories and photographs; the pages of photo albums can be viewed in random order. Individual photographs can be removed and organized in various nonchronological or non-linear ways. Slideshows can be similarly constructed. Much like memory, where images and experiences can be selectively called up in the mind, photographs can be shuffled and recontextualized to create new and novel configurations. Photographs make memory a concrete social reality through resemblance and function via the variety of ways they are inserted into the discourses of social life.

The touristic inclination, facilitated by the material forms of photography, shares an affinity with another central fixture of nineteenth century social and economic discourses. Just as the rapid growth of the middleclass helped to define and value photography through commodification, ${ }^{103}$ the trope of the flâneur embodied the rapid metamorphosis of the urban landscape of second-empire Paris through a relationship to the city facilitated by commodity capitalism. ${ }^{104}$ Akin to the operations of tourist photography, the flâneur mediated and transformed the visual experience of urban life into an image, often through a second hand deployment in literature or artworks that described Paris and its denizens. The flâneur was both medium and sign for changes in the nineteenth century city. The totality of this transformation of into a set legible signs was not unlike the panoramas, popular attractions during that time. Such panoramas were large-scale painted scenes of cities, landscapes, or historical events housed in large theatre-like rooms whose purpose was to present a life-like approximation of reality and 
by extension the opportunity to experience it as well. ${ }^{105}$ According to Benjamin, the flâneur was a dweller of city streets, a person whose ramblings enveloped the space of the city and made it like the interior space of a house or home. ${ }^{106}$ Photography's ability to miniaturize the world and bind it within the four edges of the frame is not unlike the flâneur's experience of the city as a room or interior space and its requisite "four walls." ${ }^{107}$ The transformation of experience into a concrete, limited, and ultimately knowable form is made possible by its insertion into discourse. For many contemporary critics, the flâneur and his relationship to the city encapsulated a new means for understanding the urban landscape as concept, picture, and sign.

Even outside the shared socioeconomic conditions that gave rise to the tourist and flâneur, ${ }^{108}$ these figures share a common predilection towards modernity and its developments. Namely, the most meaningful and valuable experiences are those defined by some relationship to the world via its objects. ${ }^{109}$ Benjamin condenses this in a rather striking way and calls this an "empathy with inorganic things." 110 This implies an emotional exchange between person and object: not just feeling but feeling what an object feels. The tourist responds to the world in a similar way: emotions are drawn out, solicited by things, objects, and places and therefore experienced differently than those encountered in the "everyday world." fostered by the discursive forms that in turn solicit it. Images and descriptions, like those identified by Bourdieu that appear in travel guides, instill certain ways of seeing, understanding, and emotionally experiencing the world. ${ }^{112}$

This person-object empathy is conducted through those material forms that dictate the value and reception of the knowledge they contain. Take for example the Blue Guide 
travel companions Barthes discusses in his 1957 anthology Mythologies. Barthes describes the Blue Guide as an example of bourgeoisie mythologization, a process that makes objects and signs seem natural or essential rather than products of historical, social, or other discourses. ${ }^{113}$ In short, a myth is an empty sign that attempts to hide what systems of ideologies make it legible. In the case of the Blue Guide, its mythology represents a form that "reject[s] both explanation and phenomenology" and instead employs the "mystification" of spectacle to both generate and document place as a pure experience. ${ }^{114}$ Barthes claims the Blue Guide "scarcely knows landscape save in the form of the picturesque," word picturesque is no accident, and refers to an eighteenth century artistic and architectural movement concerned with the natural landscape and its appropriate appearance in works of art. The picturesque was what looked best in a picture, beauty that balanced natural elements into a pleasant whole. The world was shown at its most ideal, most natural, and most real. These forms, the picturesque painting and the Blue Guide, make much the same claim about the world; it is the truest, realest form of reality that they depict and embody.

The travel guide, as surrogate for the experiences of things like places of interest or monuments, augments reality through its prescription of the intellectual or emotional responses it deems appropriate and authentic. To adapt a term from Jean Baudrillard, the travel guide is also "hyperreal." ${ }^{, 16}$ It overrides the geography of its depictions by a movement beyond supplement to a substitution of its own experience for the experience of reality. While it is used to provide general knowledge about the world, the travel guide also encourages the tourist to take up its own visual, physical, and emotional position in 
relation to the world. Innocuous recommendations on what to see and do and where to do it become the stuff of empathy. The Michelin Guide's "number of bathrooms and restaurant forks" mark the best possible versions of an individual experience. ${ }^{117}$ This is not unlike the relationship between viewer and Gardener's Sketch Book. Wishing to see the "real" war, its audience was possibly driven by the same morbid curiosity that spurred crowds to spectate some of the Civil War's earliest skirmishes. Gardener's Sketch Book might also be likened to the best view, chosen Michelin style, for those interested in war's spectacular mayhem. The overt nature of the material appearance of William Eggleston's Guide comes as no accident either. The book resembles a photo album and its name references a popular and long-running travel companion. There is a consciousness to the way its materialism solicits viewers to understand and contextualize its images. Yet at the same time it denies the viewer the full utility of this apparent function. As Bourdieu explains, the tourist's snapshot photograph, a form that Eggleston engages,${ }^{118}$ relies almost exclusively on the further mediation of descriptive commentary. Yet Eggleston's engagement foregoes this commentary entirely. By themselves his photographs offer very little in the way of value as coherent knowledge of the world they depict. ${ }^{119}$ Vague place-names provided as titles, found in both William Eggleston's Guide and Election Eve, withhold the kind of meaning their forms initially suggest. There is a stark contrast between the outward appearances of the books and a coherent indication of what its images might actually communicate.

In its most basic form, the travel guide offers very select and heavily edited views of the places it describes. Eggleston's photographs also share this narrow range of specificity. Election Eve appears to be very explicit in its commentary: maps in the back 
of each volume, coupled with the place-name titles of photographs, provide a constructive and utilitarian raison d'être. Yet the inclusion of a map is curious even for a set of photographs interpreted to describe real places in the real world. As Barthes indicates, the travel guide is only useful in regards to the individual pieces and fragments that constitute its specific geography. Apart from elements like monuments, sights, and amenities, "it answers in fact none of the questions which a modern traveller might ask in crossing any terrain which is real and which requires time to cross." ${ }^{, 120}$ A map provides this through context. Things like scale, relation, and distance are figured according to how map and place relate and the means by which one is legibly transformed into the other. Not unlike the panoramas of nineteenth-century Paris, the map offers a view that singular, uninterrupted, and fully perceptible. Yet it is also an artifice that is purposely and consciously taken for granted. ${ }^{121}$

The map also plays the role of surrogate in addition to its role as a representation or description of reality. It accomplishes this through the ways it addresses what Latour calls its "“micro, 'meso,' and 'macro"” relation to the world. ${ }^{122}$ Unlike the painted panoramas of nineteenth-century Paris, the map doesn't usually fall victim to an "excess of coherence" that undermines its ability to mediate reality in an effectively transparent way. ${ }^{123}$ Specialization also helps to mask the map's built-in limitations: targeted elements like topography, geology, boundary, or navigable routes provide knowledge whose utility helps gloss over the map's artificial construction. ${ }^{124}$ This succeeds because of the disconnect between its material form and didactic role. Like the photograph's "that happened" assertion that offers proof through discursive use, the map asserts a similar "that is." In this sense, a place exists truthfully only when it appears on a map. The ways 
institutions construct, organize, and control knowledge through the systematic valuation of raw data results in official designations of place. This process also enables a viewer to authoritatively state "I am here" or "I am not there." Much like the photograph, the map also accomplishes this feat through willful deceit, through the knowing exchange of reality for its effect. The map functions as its own reality and viewers must find it legible in the same way that the geography it points to is legible.

Jorge Luis Borges offers a fictional assessment of this exchange in his 1946 short story "On Exactitude in Science." The story describes the map of some empire that is expanded until it reaches the seemingly impossible scale of 1:1; the land and the map eventually occupy the same physical space in the world. ${ }^{125}$ Despite its perfect accuracy, the map is ultimately abandoned because it proves cumbersome and therefore useless. In effect, the map is unable to serve its intended purpose as a map. It can no longer be defined as a map. It can instead be considered co-equal to the empire because it coincides "point for point" with it. ${ }^{126}$ Umberto Eco further interrogates this equality between what are essentially a sign and its referent. In his analysis of Borges's story, Eco demonstrates that the map reproduces all things within itself. He calls this the "ideal condition" of such a map, one in which resemblance affords the same (or same kind of) subjectivity and identity possessed by the empire. ${ }^{127}$ According to Eco, such subjectivity necessitates "self-awareness;" the map becomes the empire itself. ${ }^{128}$ In the way that Borges attempts to describe the futility of "exactitude" in the realm of this particular discourse, Eco twists but likewise demonstrates how the literal transcription between material forms is ultimately doomed to failure. 
Certain caveats, especially teased out through material connections between sign and object, can expand the definitions put forth by both Borges and Eco. According to Latour, the weakness of the panorama's position as a true or authentic surrogate for the experience of reality was located in an overabundance of coherence. ${ }^{129}$ Even then, it is perception on the part of the viewer that ultimately determines success or failure. While its assertion of "gaplessness" mystified the panorama's view, ${ }^{130}$ the gaps that inevitably appear can actually contribute to the sense that the thing itself rather than the thing depicted might be real or truthful. The maps explored by Borges and Eco are rooted in the necessity that they appear gapless in relation to the discourses to which they belong. Yet the direct experience of such maps runs counter to the goals of their uses. The functional value of the map as a sign is tied directly to its material form. The map relies less on the perfection of its reproduction than on the utility of its object. It is for this reason that less-than-perfect map projections are still useful. Exactitude does not preclude errors as long as those errors fall within tolerable limits. Map and place do not need to be the same scale or have the same level of detail for the map to be taken as useful, truthful, and real. As Keane states, the two must simply "count as the same thing.",131

Like Eggleston, Stephen Shore has focused much of his practice on a quotidianesque photography of places. One such project is Shores's American Surfaces, photographed between 1972 and 1973, exhibited at the Light Gallery in 1973 and MoMA in 1974, and finally published in its complete form in 1999. In this series that numbers some 220 individual photographs, Shore documents several trips from New York City to Amarillo, TX, and various places in between. Over the course of this extended road trip, Shore shot the more banal particulars of the places he and his companions came across. 
Cars, asphalt roads, roadside motels and motel rooms, sparse diners, and plates of food feature prominently, as well as some of the people who haunted the partially anonymous locales Shore encountered in towns and at the intersections of various highways. Shore initially took his amateurish snapshot aesthetic to its material ends. Rather than professionally print and frame his photographs, Shore had them printed by Kodak and mounted twenty of them, unframed, directly onto the wall of the Light Gallery in a large running grid. The photographs were haphazardly arranged, hardly concerned with a neat or readable narrative structure. Taken together, this configuration presents a kind of summary of Shore's experience on the road. In a review for Artforum, John Collins compared Shore's pictures to an earlier project where he likewise literalized the intent of the photographs's formal presence by printing them as picture postcards. ${ }^{132}$ Collins also admitted (somewhat reluctantly) that they represented a connection between depiction and reality that seemed to prioritize the artistic version as the more compelling of the two. "To go somewhere photographically," Collins said, "is often more interesting than going there in reality." 133 In effect, the truth of Shore's photographs lies in the way they are configured in relation to each other as components of a larger explored geography. As a book, the sequential flow of American Surfaces also draws value from the means of its presentation. When they were put together and published in 1999, the photographs were reorganized into chronological order. This allowed viewers to literally follow Shore's routes. Because flipping through the pages of American Surfaces is sequential and chronological, it moves the viewer forward in time and direction in relation to the places and events the photographs depict. Often, groups of photographs provide structured experiences of specific places. They accomplish this through the 
juxtaposition of exterior and interiors shots as well as pictures of the people and things encountered in those locales. Two such photographs, both titled Holbrook and taken in Holbrook, AZ in June 1972, appear to provide such a tangible continuity. The first (Figure 11) shows a large faded red, white, and blue motel sign inconspicuously set in a gravel lot. To the left in the distance is a restaurant that promises "Chinese and American food" and souvenirs. To the right are more motel signs attached to their respective buildings. The second picture (Figure 12) is the interior of a bathroom. The reddish log beams in the walls and red-brown tiles that compose the sink's backsplash echo the faded red bricks of the motel sign from the previous photograph. Though there is no explicit relationship between the exterior and interior shots, the overlap of titles and physical and aesthetic juxtapositions provide the viewer with an impetus to link them together in a meaningful way.

Beyond these immediate contingencies, Shore provides more nuanced takes on the chronological documentation he engages with throughout the project's course. Two photographs, taken in Alanreed, TX in July 1972, seem to have been taken minutes or even seconds apart; Shore might have simply pivoted his body from one subject to the other to take the two pictures. The first Alanreed (Figure 13) is shot from above and shows a dark wooden end table with a small brass lamp, a small black and white portrait photograph in a metal frame, and a glass bowl filled with artificial fruit. The table sits in a corner next to a doorway, the right side of which is barely visible on the extreme left of the photograph's frame. The wall to the right of the table is composed of rough quartz and other stones held together by concrete, mortar, or some other similar substance. This wall repeats in the second Alanreed (Figure 14) behind an elderly man in a striped long- 


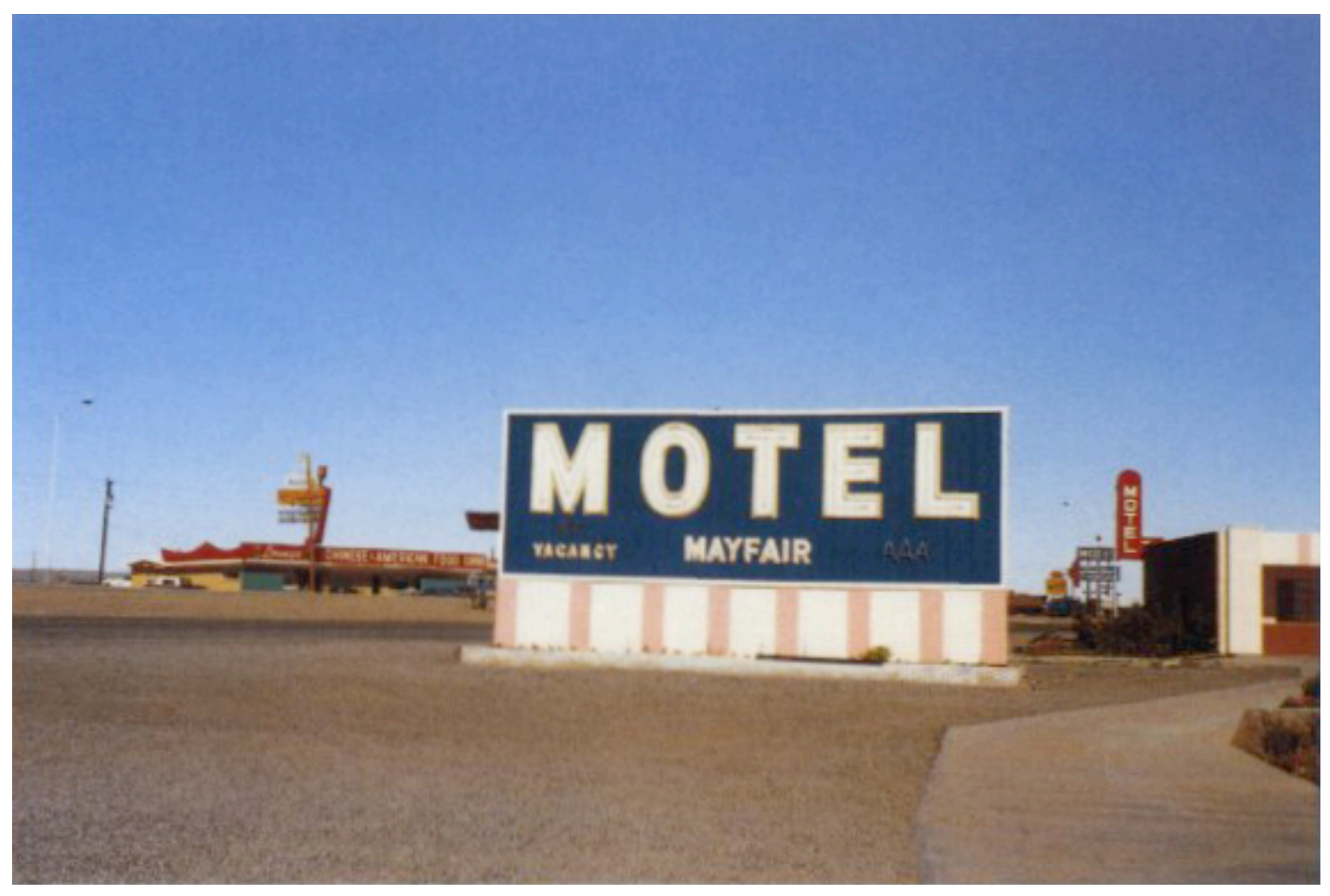

Figure 11. Stephen Shore, Holbrook, 1972, Ektacolor print, 5 x 7 1/2 in. 


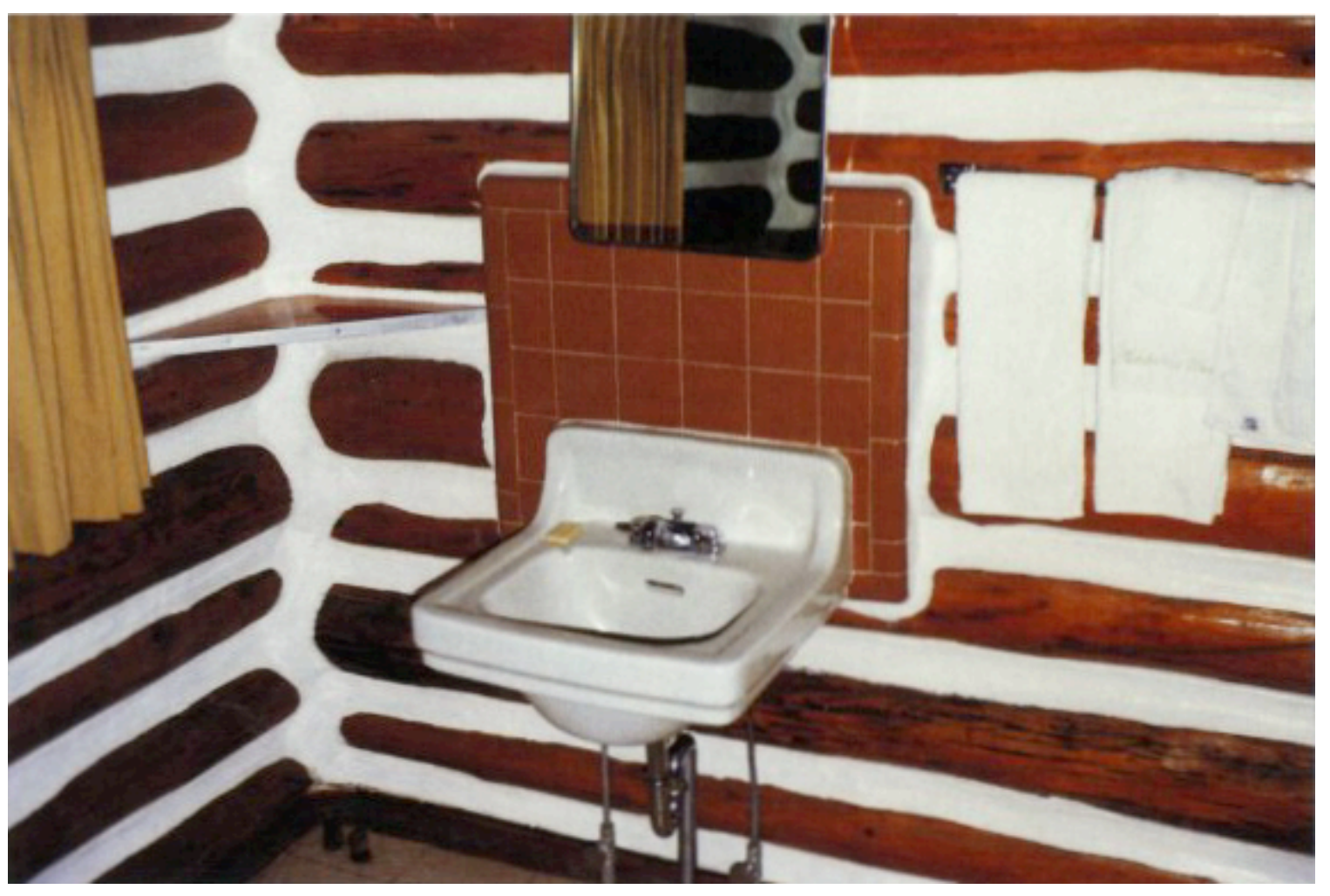

Figure 12. Stephen Shore, Holbrook, 1972, Ektacolor print, 5 x 7 1/2 in. 


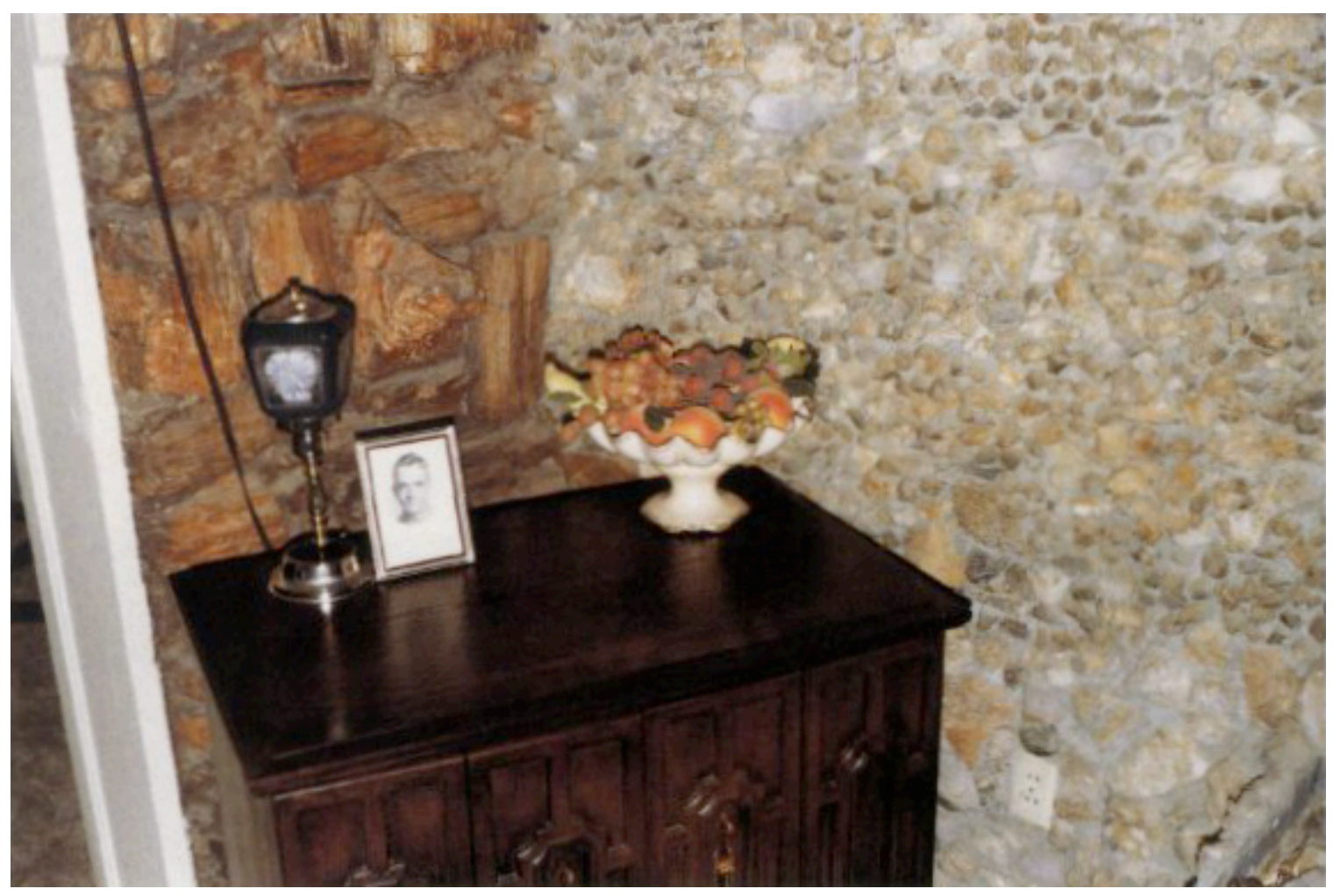

Figure 13. Stephen Shore, Alanreed, 1972, Ektacolor print, 5 x 7 1/2 in. 


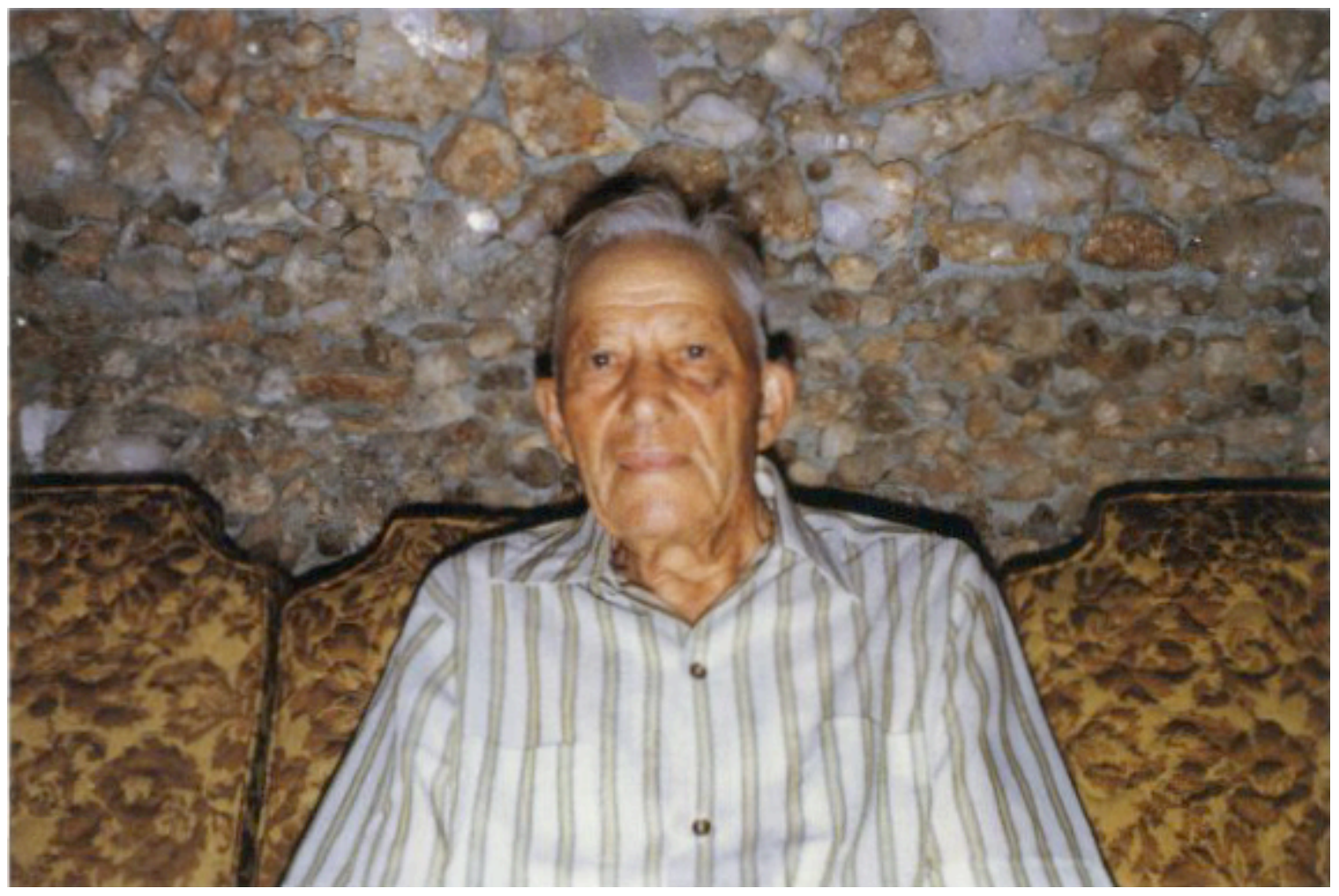

Figure 14. Stephen Shore, Alanreed, 1972, Ektacolor print. 5 x 7 1/2 in. 
sleeved shirt who sits on a quilted mustard-and-brown-colored couch. Both photographs were shot with the same harsh flash and in the same proximity to their subjects. Close inspection reveals that the man in the second picture resembles a much older version of the small face in the black and white photograph that sits on the table in the first shot. This direct and literal reference solicits the viewer to understand the purpose and function of Shore's photographs in a very specific way. The chronological succession of time is represented and reproduced through multiple physical juxtapositions: subjects, photographs, and the book's schema all elicit the same ties between depiction and reality.

A third set of photographs is much more subtle but much more indicative of Shore's awareness of the material consequences of reality's effect. The first is Kanab (Figure 15), a frontal shot of a wall and framed painting taken in Kanab, UT, in June 1972. The wall is covered in a patterned wallpaper that carries stereotypical renders of Native American culture: a decorated quiver and leather pouch, a stone axe and arrowheads, line drawings of buffalo and buffalo hunting, and a stretched hide with the image of a man in a large feather headdress. The painting that hangs on the wall is a fairly innocuous landscape, probably painted by an amateur artist, and features a small cottage and large tree next to a stream crossed by a small stone bridge. The individual details in the photograph are fairly generic, but their combination is memorable. Near the end of the book, 206 images, nine months, and some 2,400 miles away, is New York City (Figure 16). In it a person clutches a stack of drugstore prints. On top of the stack is Kanab. Taken sometime between March and April 1973, this photograph is centrally focused the tiny print and its tiny image. The viewer looks over the shoulder of the figure that looks through the stack of prints. The figure also functions as the viewer's surrogate. 


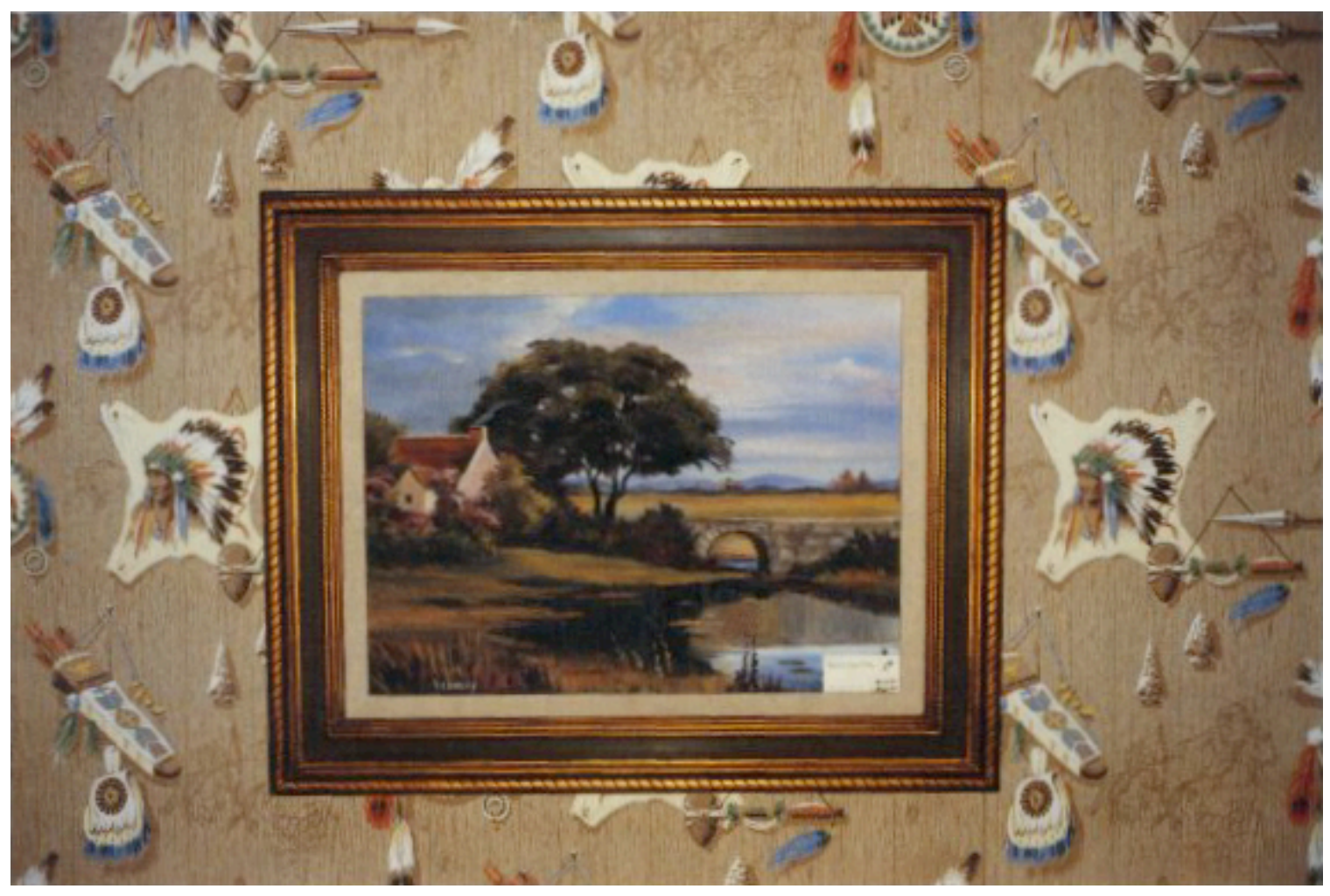

Figure 15. Stephen Shore, Kanab, 1972, Ektacolor print. 5 x 7 1/2 in. 


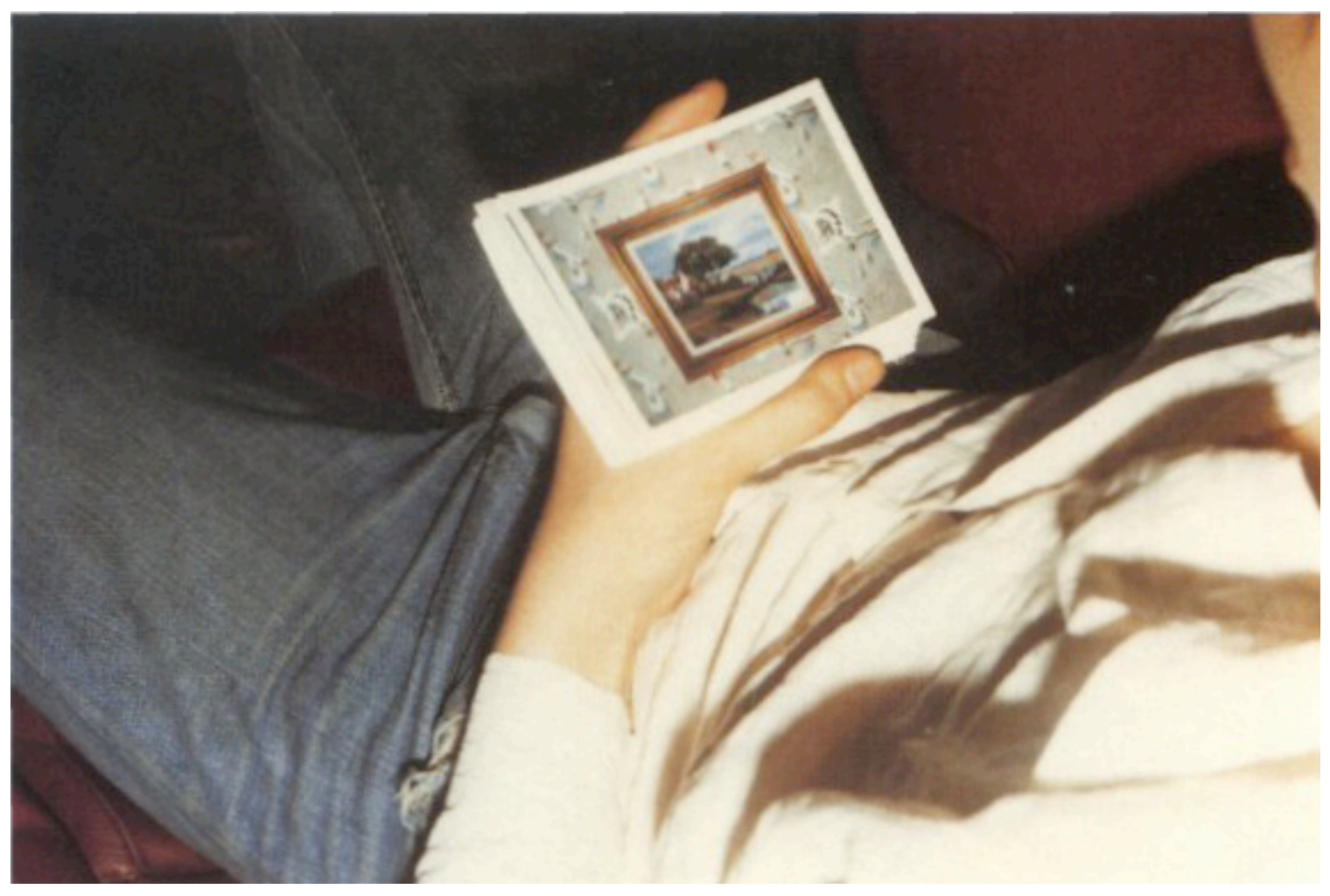

Figure 16. Stephen Shore, New York City, 1973, Ektacolor print. 5 x 7 1/2 in. 
Defined as an object, subject, and in reference to the role it plays as mediator of experience, this photograph seems to render the project even more factual and more deeply rooted in reality than its titles and images suggest. At least, that is what New York City implies. These photographs are ultimately meaningful because they are presented as functionally subservient to the "actual reality" of what they depict and their utility as documents. American Surfaces was initially displayed in an unbroken grid that spanned the walls of the Light Gallery in New York. Without the added coherence of sequential or linear logic, the photographs were generally taken at face value. Like his earlier picture postcards, the photographs Shore produced were formally identical to an amateur's vacation snapshots. ${ }^{134}$ In many ways this was Shore's intention, but as Marta Dahó points out, the overtly "deliberate" nature of this approach is due to more than just an approximation of the snapshot's visual conventions. ${ }^{135}$ Shore's addition of an extra layer of transparency to objects already staked to claims of neutrality instead reveals the weakness of such claims. His obvious allusions to the photograph's content as something wholly external sows doubt at its ability to observe and report truthfully. A photograph of a photograph makes this function overtly artificial and further fragments claims to an effective and authentic representation of reality. Yet this is Shore's intention all along. American Surfaces is about taking pictures, and the viewer is in on it. 


\section{CHAPTER IV}

Eggleston's photographs are neither obvious nor forthcoming about their usefulness or trustworthiness as documents and purpose as objects. Election Eve ultimately lacks the logical coherence of sequential or linear time that can be ascribed to its formal and historical precedents. The titles printed at the end of each volume reveal a variety of places names that range from the broad (Mississippi) to the specific (Plains, Americus, Friendship). Yet the locations seem peppered haphazardly down the list of plates and their specificity of the titles is ultimately misleading. With titles available, flipping directly from print to print follows neither the logic of time's procession nor direct routes from place to place. Instead the photographs appear to be connected by purely thematic or visual connotations. For example, in the first volume, a photograph (Figure 17) of a red clay cemetery, populated by a few dusty illegible headstones and bordered by large gnarled trees, is followed by a close-cropped shot (Figure 18) of a clapboard shack with several faded Coca-Cola signs tacked next to a screened door that is half-obscured by an overgrown bush. The proceeding picture (Figure 19) shows a roughplanked porch shot at an incredibly low angle. In the center of the frame is a small white bucket and to its left a chipped cooking pot and coffee can. At the extreme right of the frame the toe of a brown shoe and part of a tweed pants leg are just visible. Though mundane, this three-photograph sequence demonstrates an initial logic; taken together the 


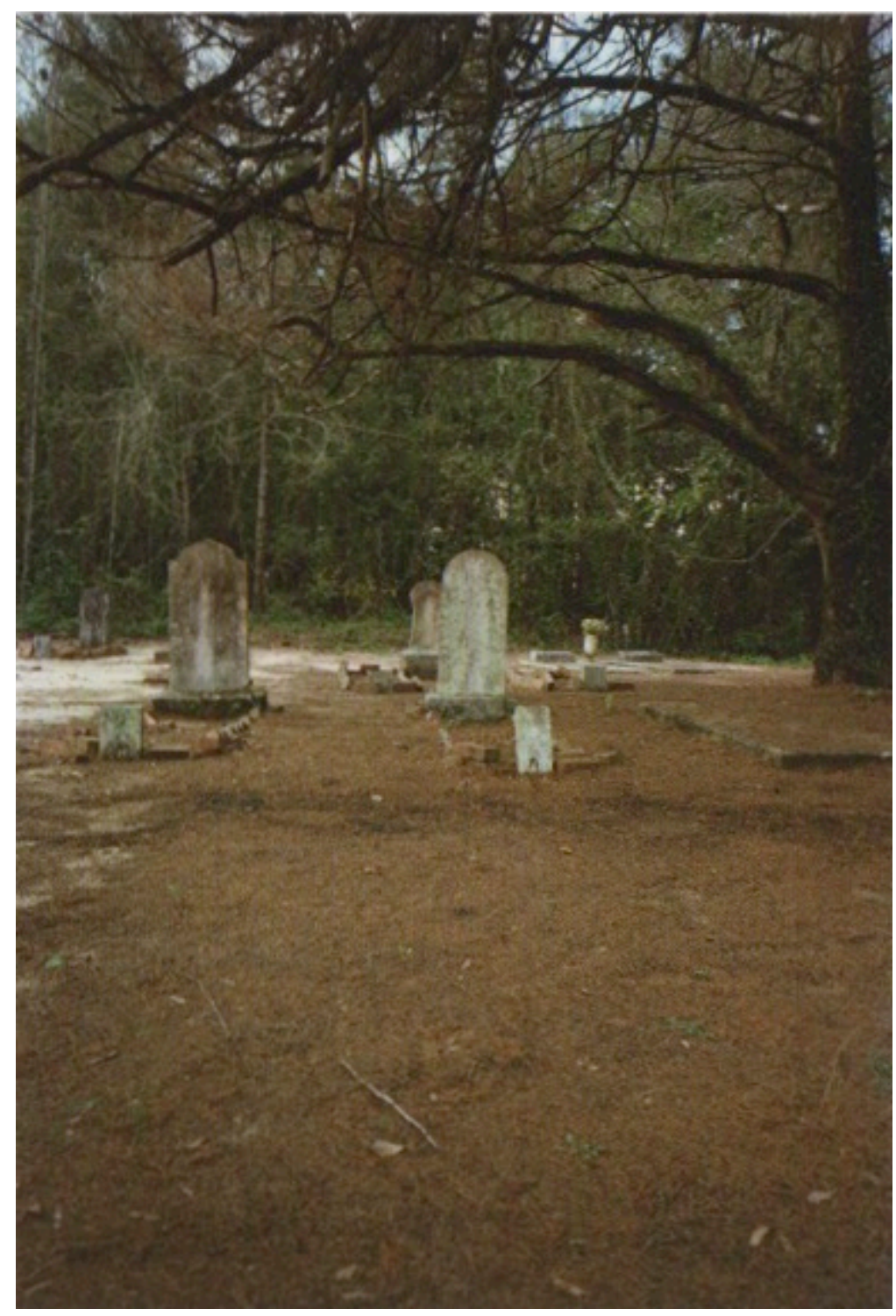

Figure 17. William Eggleston, south of Plains, 1976, Chromogenic color print, 15 x 10 $1 / 4$ in. 


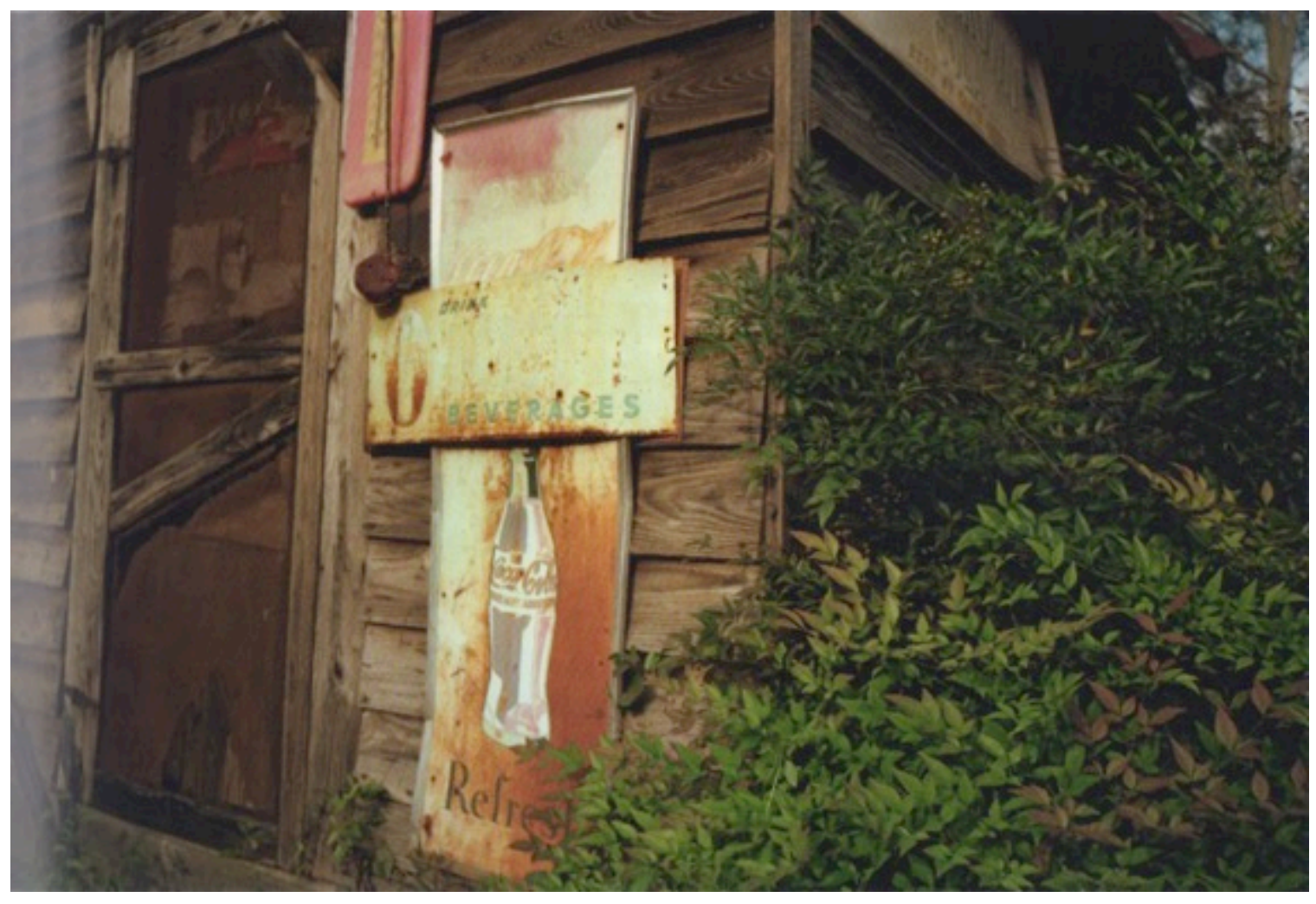

Figure 18. William Eggleston, Plains, 1976, Chromogenic color print, 10 1/4 x 15 in. 


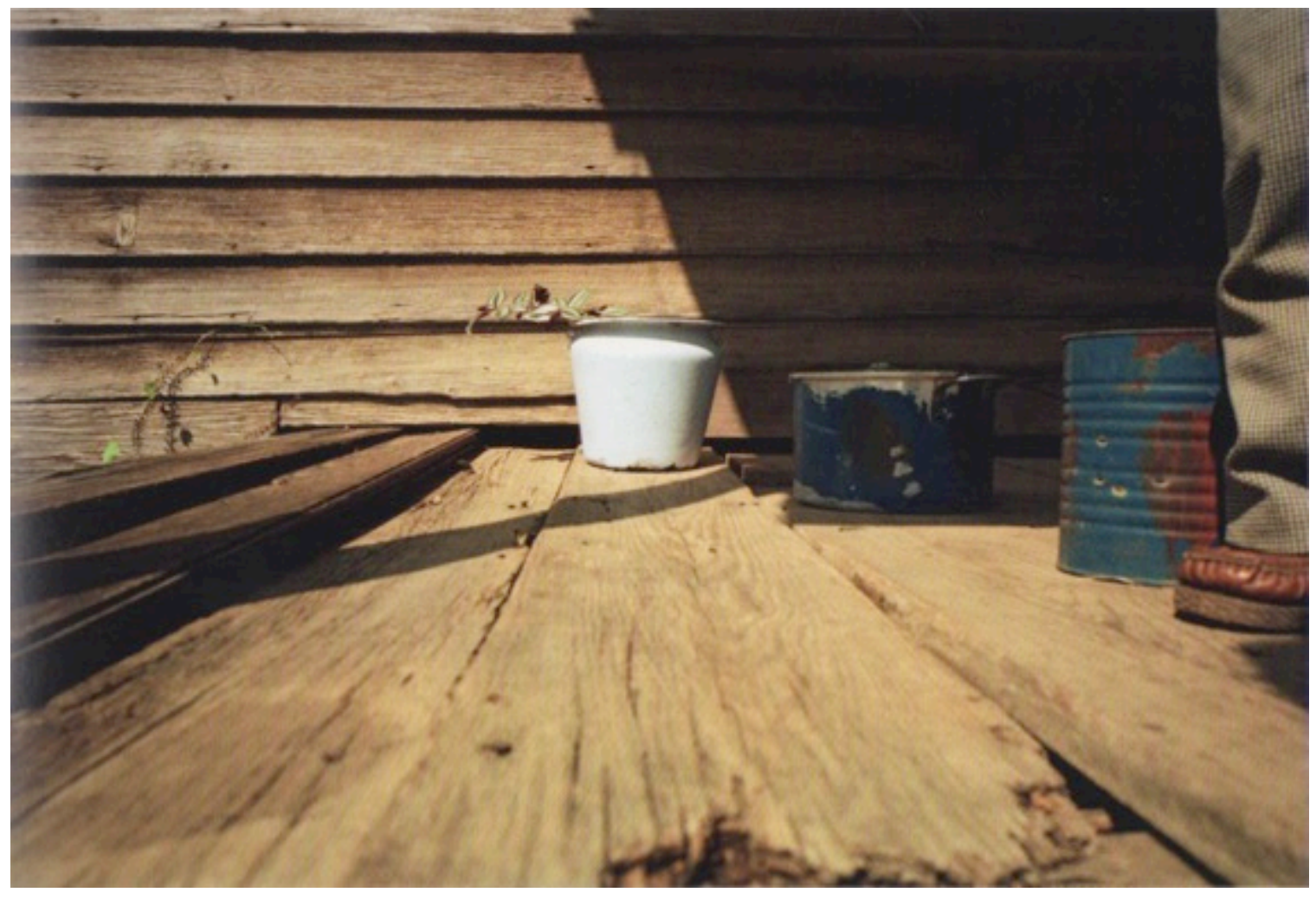

Figure 19. William Eggleston, Sumter, 1976, Chromogenic color print, 10 1/4 x 15 in. 
photographs could represent an old house situated near a family cemetery. But their titles provide something altogether different and largely nonsensical. The first two are titled south of Plains, and Plains respectively, yet even here no indication is given as to their relative proximity. The third image in the sequence, the porch with its foot and leg, is called Sumter, a place that is ten miles to the southeast according to the provided map. While the visual and thematic implications of the prints and their juxtapositions are quite suggestive, the titles and their none-too-specific locations seem hardly cohesive if at all. In fact, the trip to Sumter that led to the photographs in Election Eve is itself fairly ambiguous. Fonvielle's preface describes Eggleston's journey as "warily" circular, at best a vague indication of the route that Eggleston took from his home in Memphis, TN to Plains, GA. ${ }^{136}$ In this respect, the map is quite puzzling. Rather than provide specific information about the means by and through which Eggleston traveled to Sumter County and made the photographs that were included in the book, the map instead contextualizes in a very general way the reality of the photographs through a contiguous relation to one another and to a larger geography. The map bears witness to the fact that each photograph corresponds to a knowable location confirmed through the corresponding identification of title and name on the map. Beyond this the map provides scant information. It shows the outline of the county and identifies ten towns or cities, two rivers, and eight highways. Also included are a compass, scale, distance and direction to the cities of Memphis and Atlanta, and an inset view of the Southeast United States with the relative of position of Sumter County. The only tangible connections between the photographs and the map are place names. This overlap corresponds to what Barthes defines as the limitation of the

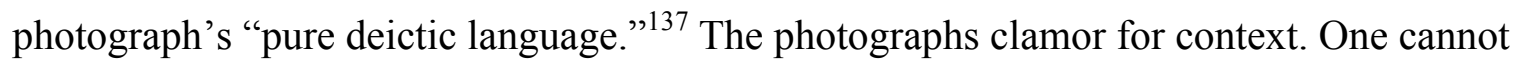


help but tie the images together especially when all the tools to do so are provided. The sequence of south of Plains, Plains, and Sumter continues with a photograph (Figure 20) of the left side of a house, shot low, whose weathered porch juts towards the viewer, towards the right, and out of the fame. The next photograph (Figure 21) is a similarly ancient looking shack with a rusted tin roof and weeds that poke up all around it. The photographs seem to point at each other and the connotations are hard to resist even as their respective titles, side yard, unkempt house, Plains and near Americus, ping-pong across the map.

Added to this sense of aesthetic or thematic coherence is a uniformity of conditions across the photographs. Nearly all the images appear to have been produced under a similar diffuse daylight. While a few show rain or overcast skies, such photographs do not significantly undercut the overall sense of concurrent and temporal sameness. Movement through the book from photograph to photograph gives little indication of the passage of time from day to day. Instead, the relative similarity of the images feels like the product of a single afternoon of picture taking even though Eggleston probably took several days to visit all the places he did. ${ }^{138}$ In this respect, the photographs appear much closer in distance to one another than their locations, once betrayed by their titles, actually indicate. Unlike Stephen Shore's road-trip diary, punctuated by days and nights, interiors and exteriors, and a whole array of appearing and disappearing figures and locales, Election Eve's progress is so seamless as to be invisible. Any sense of the time it would take to actually travel from Memphis to rural Georgia is nonexistent. This effect has much more in common with Sonneman's diptychs: Eggleston's photographs truncate their shifts in time and distance into a nondescript 


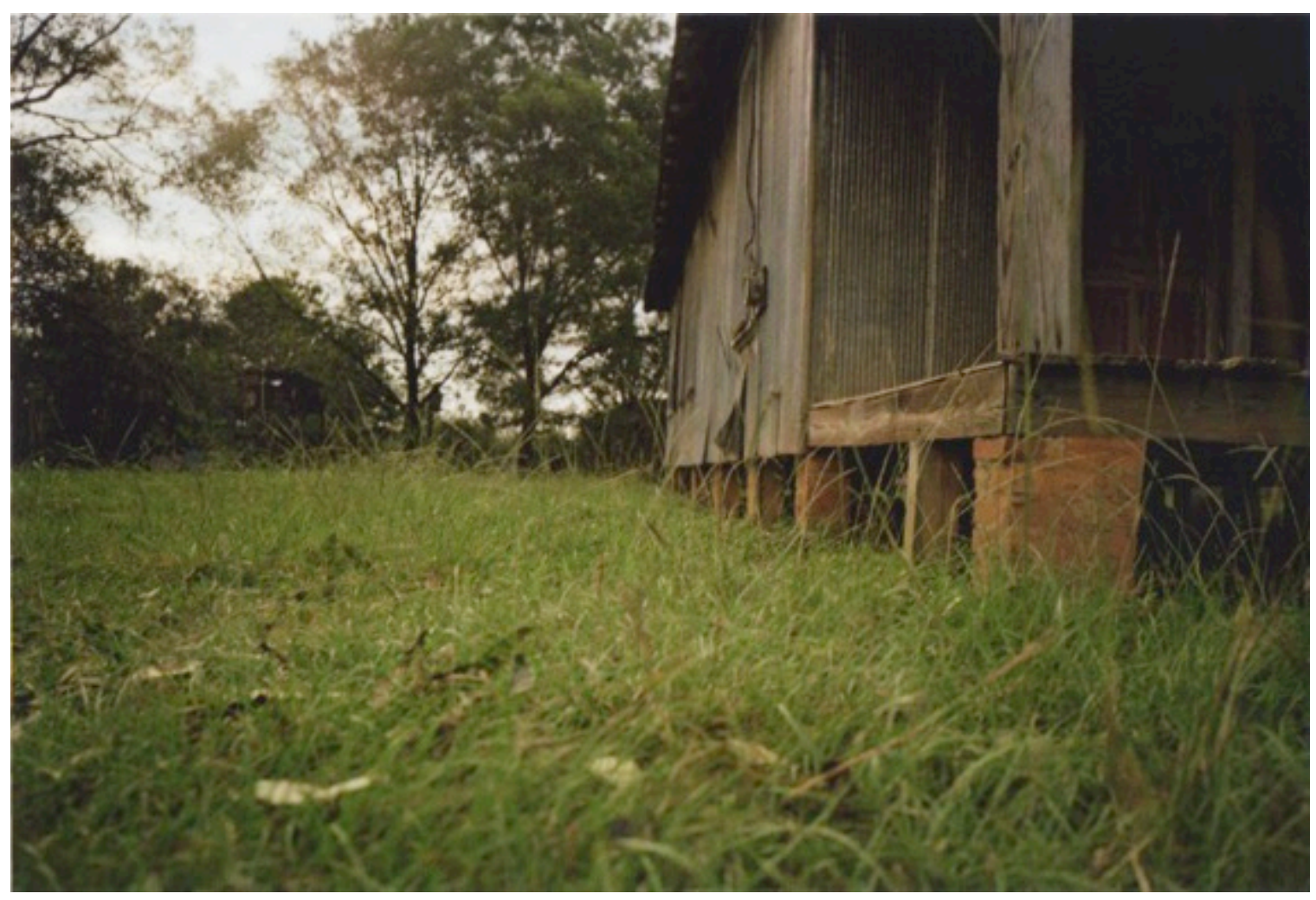

Figure 20. William Eggleston, side yard, unkempt house, Plains, 1976, Chromogenic color print, $101 / 4$ x 15 in. 


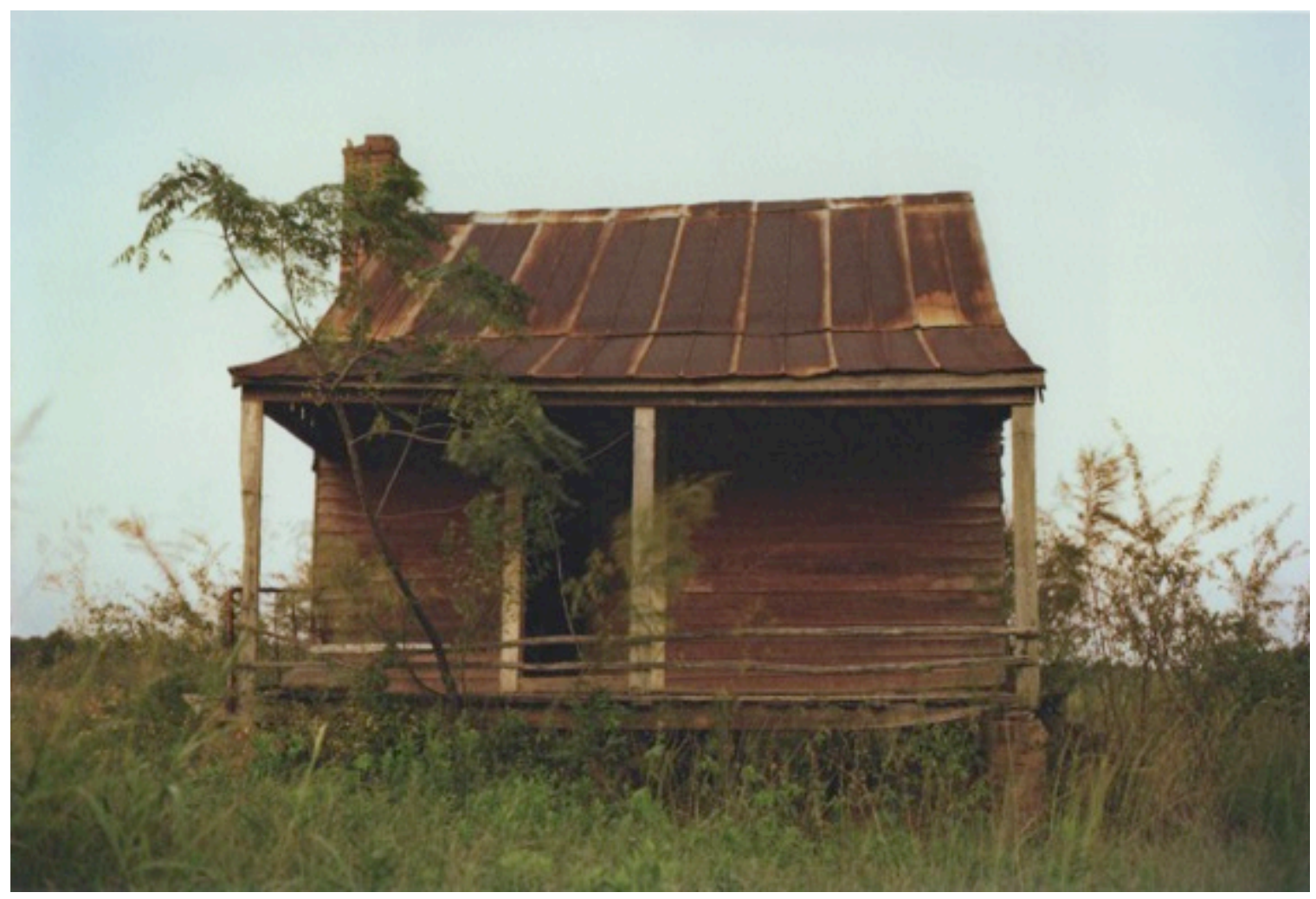

Figure 21. William Eggleston, near Americus, 1976, Chromogenic color print, 10 1/4 x 15 in. 
continuous flow between sets of important points. Yet unlike Sonneman's photographs, the illusion of succession is much less stable or secure. While both tweak the tropes of Cartier-Bresson's The Decisive Moment,${ }^{139}$ Eggleston does so by pushing this sense of the moment beyond the space of a few bookending frames ${ }^{140}$ into broader yet more nebulous territory. If the book's title is any indication, Election Eve alludes to its timeframe in at least two ways. It is a specific day before another day, or a more indeterminate period that precedes some momentous event, occasion, or even epoch. Both possibilities appear to be valid. Election Eve indicates both a single day in advance of the 1976 presidential election as well the tense anticipatory run-up, often months-long, to a possible shift in the direction of the nation's governance.

This enclosure of time and space into a seemingly singular, coherent, and totalized form recalls the strategy of the nineteenth-century panorama. As discussed by Latour, the panorama succeeded and failed through the relative gaplessness of its presentation as a complete image. ${ }^{141}$ In addition, the panorama had to strike a balance between what was visual and what purely suggestive: too much information diluted its ability to be perceived as a coherent whole while too little called attention to its artificial construction. ${ }^{142}$ The experience provided by Election Eve is similarly frustrating. Its requisite material forms like book and photograph do not match up with their ingrained functions. What appears between the covers is not as coherent or total as it initial seems. The photographs first proceed under the assumption that they represent a knowable set of circumstances and conditions, reflective of reality, which can be readily and directly ascertained from the pictures themselves. But with the addition of the map and titles, the sequential logic of the book frays considerably. The espirit de corps that initially 
connects the photographs, book, and viewer unravels as actual utility moves further away from the assumed utility that was previously gleaned from its formal resemblances. Instead of a panoramic or narrative view of a moment and place in history, the viewer is left with a collection of photographic fragments, close-cropped pictures of the banal and faceless artifacts that populate the landscape. There is only a mass of what Barthes terms " "useless details" that seems to contribute little to the book's perceived function as a useful container for and communicator of meaning. ${ }^{143}$

The illusion of the panorama's construction is exposed when it rubs up against the "realities" of discourse and perhaps this is the point. The idea that things exist only through specific forms or contexts is central to the photographic forms I have discussed. The map operates according to this same assumption. In Latour, Emilie Hermant, and Patricia Reed's “sociological web opera" Paris: Invisible City, the authors trace the social institutions whose multifarious functions contribute to Paris's conception as a single coherent thing. In order for this identity to be legible, it must be split up and "made small," reduced to certain basic social formulations that can be easily " "taken in at a glance." "144 The innumerable parts of a huge flattened map that reside in the offices of the Service Parcellaire represent one such formulation. This map is organized and stored in filing cabinets and on a computer server and therefore is not technically contiguous. Yet this particular view of Paris is conceptually whole. Latour, Hermant, and Reed assert that this representation is not simply an abstracted or flattened distortion, but an actual site of the city's coherent identity and by extension its reality. ${ }^{145}$ Again, this identity is deictic, what Latour, Hermant, and Reed also identify as its quality as a thing comparable or otherwise translatable to other forms. ${ }^{146}$ 
Such translation creates unique connections and affinities between outwardly distinct things. According to Keane, this amounts to a reconsideration of discrete signs and objects as "the same thing" by their roles within discourse. ${ }^{147}$ Even where semiotics clings to a "radical separation of the sign from the material world," "148 this assumption might actually be embedded in and therefore inextricable from the material forms signs invariably take. Keane defines this phenomenon as "bundling:" qualities "must be embodied in something in particular" and so signification is often difficult or impossible without being transmitted by material forms. ${ }^{149}$ This is not unlike what Benjamin describes as the aura of objects. Here as well, physical presence and meaningful function are tied together. ${ }^{150}$ For Benjamin this corresponds to the unique and authentic quality of (specifically) art objects, their reality as things in the world, and their relations to viewers. ${ }^{151}$ When reproductions are made the aura is depreciated. The copy interrupts and reconfigures the distance that gave the original meaning through the relationship of object and viewer. ${ }^{152}$ This alienation of the original object from the means of its own signification, of the sign from its referent, can be compared to the assumption that signs are abstract concepts with little or no relation to the world. Meaning shifts its flow from out of the object to out of its representation. ${ }^{153}$ Sign and referent become bundled together in a single material form.

This sense of overlapping sameness also manifests in the phenomenon of the landmark, one of the map's most salient and necessary features. Not just a place of interest or monumental site, a landmark is a physical point that links place and map together and allows for the discursive substitution of one for the other. The landmark contextualizes reality by presenting a point of contact through which an object in space 
and its representation on a map can be understood as same thing through their shared function. Back in Paris, Latour, Hermant, and Reed sketch this out with examples of the types of exchange between maps and reality that occur through the mediation of landmarks. Enter the tourist and the surveyor. The first seems simple enough: the tourist arrives at some place and double checks her map to make sure she is indeed where she wants to be. This is accomplished by a comparison of a street name emblazoned on a large metal plate tacked to the wall of a building and the same street name displayed a map. Through the overlap of street names, accurate navigation is possible. The tourist, if she understands and accepts this relationship between the map and the world around her, can find her way through Paris without getting lost. ${ }^{154}$ This interchange is useful and trustworthy because institutions have gradually transformed the city into of a navigable city by its concurrent transformation into a navigable map. As Latour, Hermant, and Reed explain, the city of Paris has not always presented this easily legible face, and the processes that mark and define the city in such a way still continue. ${ }^{155}$

The same sort of exchange defines the production and use of landmarks. Like the tourist, the surveyor also relies on maps in order to do her work among the streets of Paris. She depends on a unique and specific set of landmarks to locate the exact points where representation and reality make contact within the context of the mapping survey. Incidentally, these take the form of physical x-marks on the surfaces of the asphalt and stone streets. Similar to the tourist, the surveyor then uses these marks to accurately position and calibrate herself between city and map. Called "unalterable landmarks," these specific points must likewise be contextualized by sets of photographs that triangulate the marks within their immediate surroundings. Ironically, the function of 
these unalterable landmarks is derived from a more archaic system of navigation. Instead of a detailed map, local knowledge was used to ascertain how a place might be accurately "traversed." ${ }^{156}$ Such bodies of knowledge were not just a means to find one's way but allowed for the concept of navigation itself. While initially arbitrary, landmarks become valuable through habitual use. Future connections between the world and its representations are predicated on the landmark's continued mediation. The map and the world can be considered the same thing despite their obvious formal and material distinctions because the landmark provides a stable connection between them.

In the sense that both maps and photographs function as signs of reality, they must also correspond on the level of discourse. Both must belong to or draw from the same systems of meaning making if it is true that one form of representation can be "compared to another." 157 While not physically or literally the same, signs and objects, if material things, must be real in the same way and according to the same measures. ${ }^{158} \mathrm{As}$ Barthes points out, a travel guide has use only when it is understood to overlap with a place that can be traveled through, an action that has implications in the real world. ${ }^{159}$ For viewers a map and corresponding photographic records of a place must exist on the same terms. Again, the inclusion of the map in Election Eve is vexing. Eggleston's play on expectations is not simply on the level of engagement with identities of content or subject matter but in the brute existence of his photographs and how their presence connects to the realities of lands, roads, cities, and people. ${ }^{160}$ Ultimately, Eggleston's photographs belong to the surveyor rather than the tourist. Where Shore's American Surfaces documents places that already exist according to their chronological and processional attachment to mapped places and routes, Eggleston's disconnected images seem to serve 
as points yet to be or in the process of being measured and made meaningful. Rather than trace the paths already in existence through the places he visited, Eggleston's photographs constitute the act of tracing itself. The photographs in Election Eve, linked together like a discreet set of individual landmarks, construct their own legible manifestation of place.

Eggleston's practice establishes the "unalterable landmarks" of his own Sumter County, a structure that undergirds and makes possible a unique kind of navigation and transversal. Transversal is not only the movement from one place to another, but a means through which a meaningful path between previously disconnected points is constructed. This is more than just routes and their distances. The map provided in Election Eve is ultimately meaningless to the images and what they depict even though it furnishes a body of knowledge that is already well-used and well-established. On the one hand, the roads as marked paths between marked locations are identified on the map by their numbers: Highways 19, 30, 280, etc. But on the other, Eggleston's photographs make little reference to this information. According to the systems by which roads are normally named and known, the roads in Eggleston's photographs are essentially anonymous. Only three photographs, Montezuma (Figure 22), Main Street, facing East, Plains (Figure 23), and Plains (Figure 24) approach any kind of legible connection to the map. These connections take the form of conspicuous street signs. In Montezuma, a white-painted concrete marker with red-stenciled letters declares the spot the intersection of Oglethorpe Rd. and Drayton St. Likewise, Main Street, facing East, Plains, provides the nameplates of the intersection of two streets: Main and Hudson. In Plains, a small road sign, just visible on the right side of the photograph, designates its two streets Main and Bond. In 


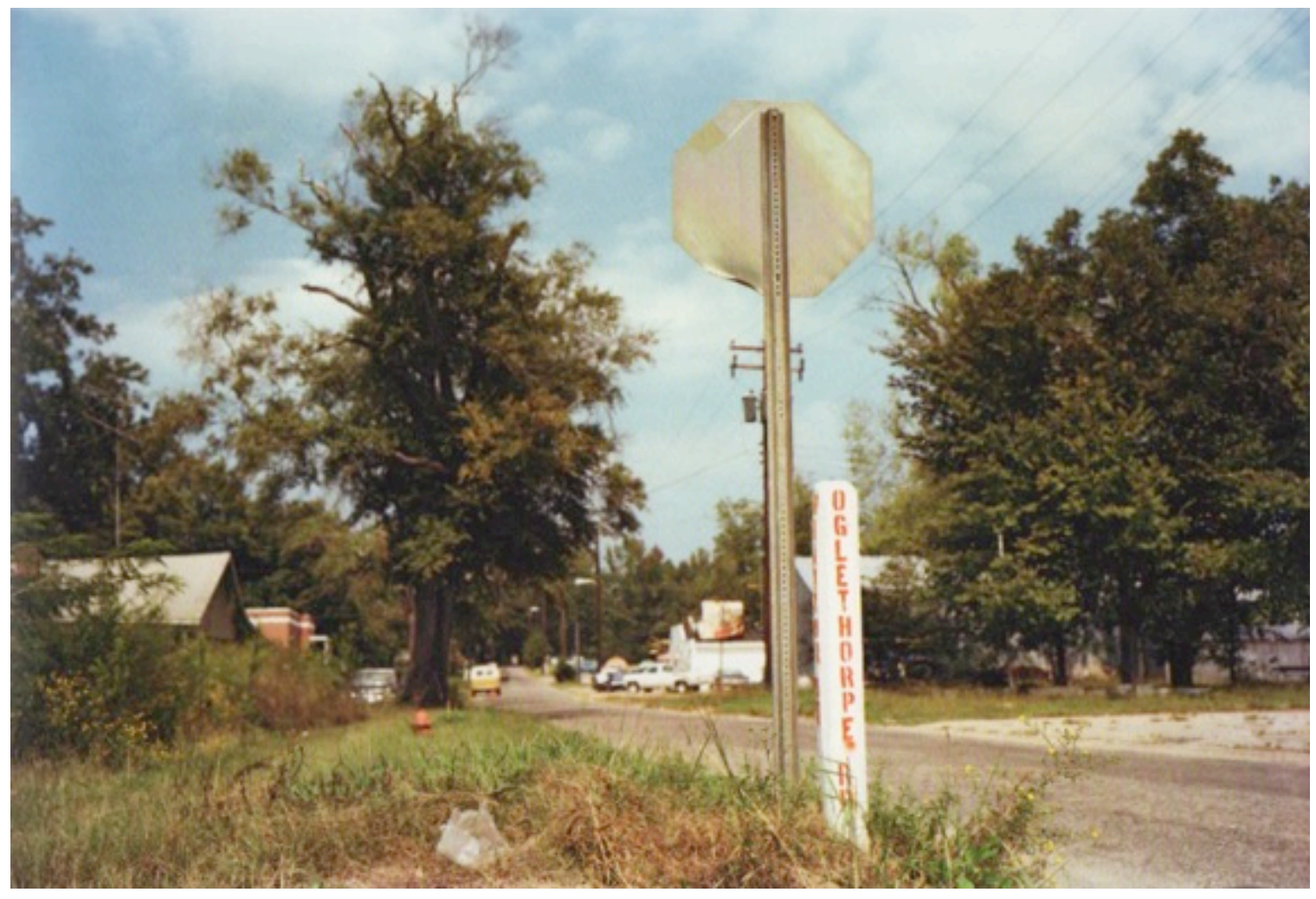

Figure 22. William Eggleston, Montezuma, 1976, Chromogenic color print, 10 1/4 x 15 in. 


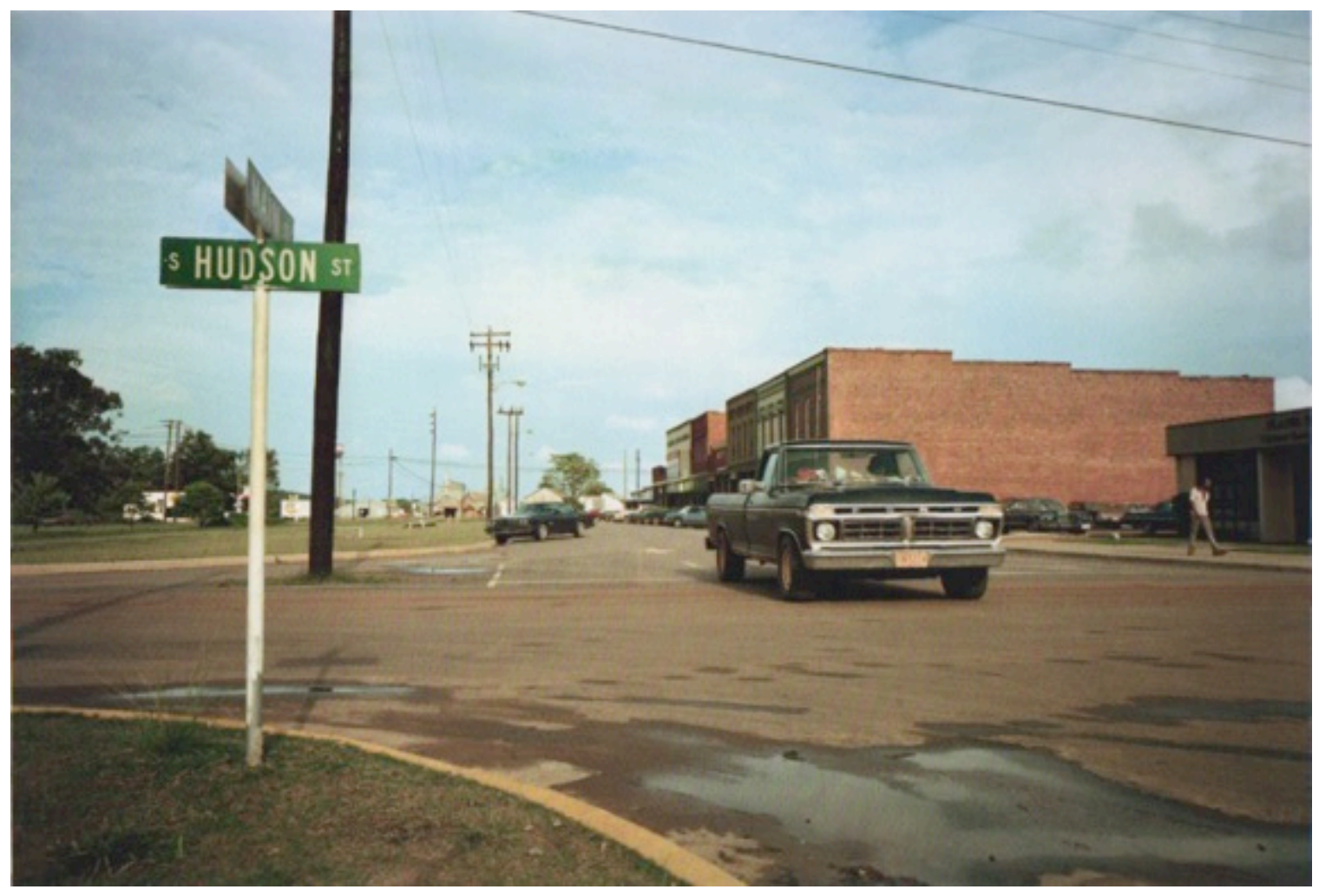

Figure 23. William Eggleston, Main Street, facing East, Plains, 1976, Chromogenic color print, $101 / 4 \times 15$ in. 


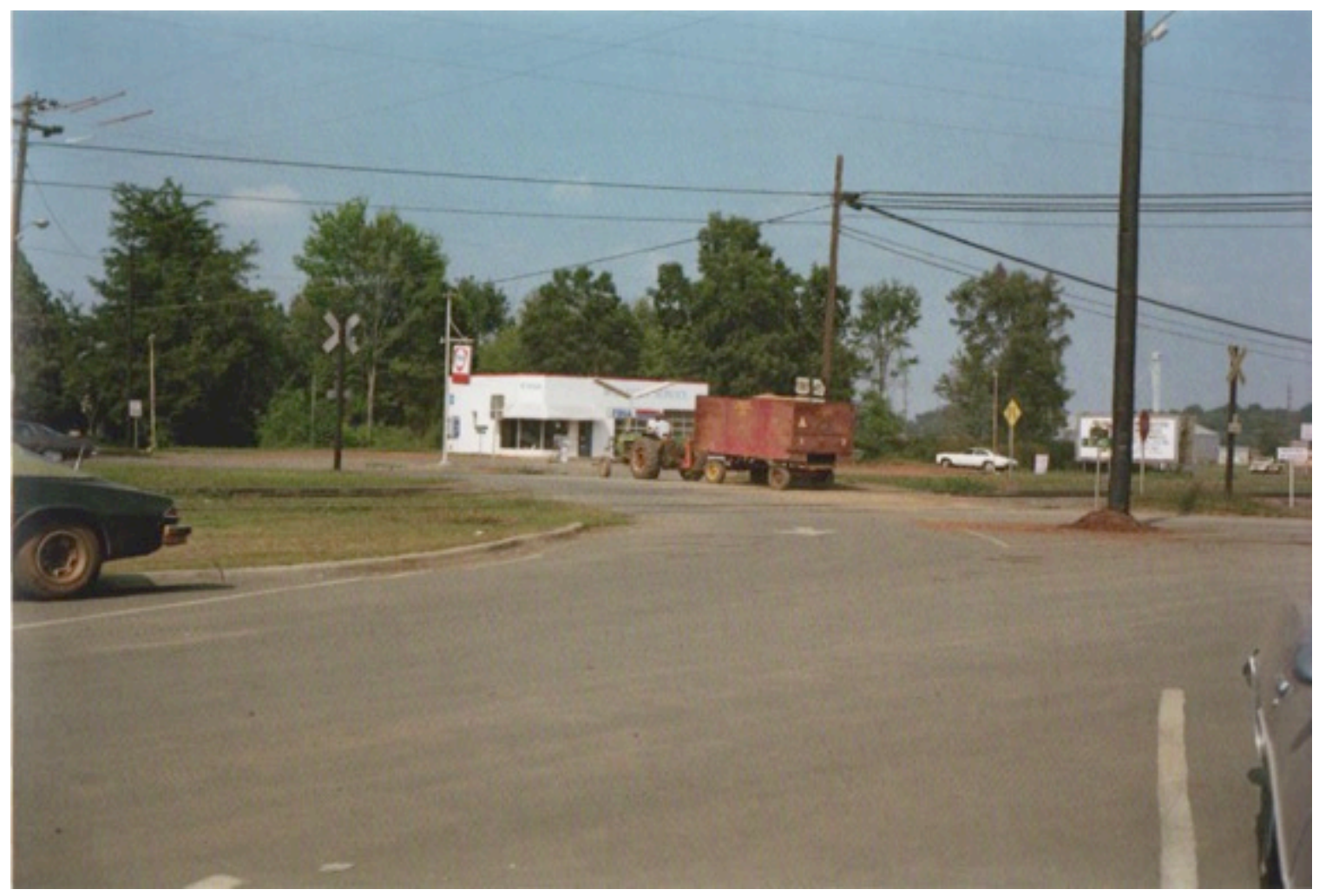

Figure 24. William Eggleston, Plains, 1976, Chromogenic color print, 10 1/4 x 15 in. 
the sense that these street names are provided and recognized as reliable and useful, an outsider to the area might be able to find them and understand how they relate to the larger geography. Yet the street names that appear in Eggleston's photographs are local and not those that appear on the map. Oglethorpe Rd. corresponds to Highway 49 but none of the other streets can be found. The already tenuous connection between photographs and their places is further muddied by the disunity of these naming conventions.

This disconnect between various bodies of knowledge looms very large across the pages of Election Eve. Even if one were to ignore the fact that the street names are technically different, these three photographs remain the exceptions. The vast majority of the pictures correspond to a realm outside of what would be useful for a tourist or a traveller. In addition, the book is large and cumbersome, effectively useless in a practical sense. While six other photographs include street names in their titles, these are much more difficult corroborate due to a lack of landmarks that correspond elsewhere. Likewise, nineteen photographs carry generic building names or other points of interest in their titles, while eight (including two of the aforementioned nineteen) indicate cardinal directions. In these instances, neither the titles nor the subjects that appear in the photographs provide enough information to definitively locate the places they purport to depict. Rather, one would need to be familiar with the area, to know what to look for. In this way, Eggleston's photographs function like those used by the surveyors to locate their own "unalterable landmarks." Coupled with the book's immensity, it is more like a separate place drawn from fragments that together mark off and establish something new. The photographs become signposts and landmarks that contextualize one another as 
points mediated between representation and reality. In this case, reality and landmark meld together through the sharing of representation.

The fragmentary yet still specific nature of these photographs is part of what makes them so mysterious despite their apparent grounding in reality. When Barthes discusses the so-called "Winter Garden Photograph" in Camera Lucida, he explains that it is enough to describe but not reproduce it. ${ }^{161}$ The photograph, which purported ${ }^{162}$ to show Barthes's mother as a young girl posed next to her brother in their grandfather's greenhouse, provided Barthes with a deeply personal and meaningful experience that lacked the appropriate context to be meaningful for anyone not Barthes or who did not know his mother. ${ }^{163}$ "It exists for me," Barthes declares, but not so for anyone else to whom the photograph is simply "indifferent," or "ordinary." 164 This is one key to the distinction Barthes makes between the concepts of stadium and punctum, elements that aid in the contextualization of photographs. The stadium is a general store of knowledge that gives the photograph a sense of time and place relative to both its subjects and the viewer. ${ }^{165}$ The punctum is much more specific. It is a "detail" that reaches out from the photograph and draws the viewer's attention towards itself. Barthes compares this effect to an "element which rises from the scene, shoots out of it like an arrow, and pierces" the viewer. ${ }^{166}$ Sometimes immediate and sometimes not, the punctum can exert a kind of will that is able to transcend the experience of the viewer's direct engagement. ${ }^{167}$

While Barthes figures the punctum primarily by its role as a thing that "pricks" and "bruises," 168 it can also be understood by its ability to connect the viewer to the spaces of reality beyond a photograph's content. The punctum acts like a tether between viewer and depiction that binds the two together like an "umbilical cord." 169 This 
connection also facilitates a continuous exchange between the viewer and the photograph. As mediator the punctum provides a special set of contextual markers that lead the viewer through the photograph to the other side, to the space of the real. It is not unlike the operation of the landmark. Both have little if any meaning outside their specific frames of reference. The "unalterable landmarks," those faded marks used by Paris's surveyors, are useless without the contingent photographs that couch them within an appropriate context. In the same way, the "Winter Garden Photograph" held little meaning except for Barthes in his grief over his mother's death.

The connections forged between viewer, photograph, and reality enable a triangulation through which the experience of looking at a photograph becomes an experience of layered reality. This occurs in both literal and figurative ways. Eggleston's photographs include physical markers that play on the umbilical linkages stretched between viewers and reality. Two such examples, south of Plains and near Friendship (Figure 25), depict headstones that jut out of the dusty clay of their respective cemeteries. The first photograph, taken from further off than the second, frames the grave markers between the fallen-moss-covered ground the huge live oaks that surround the cemetery. The second is centrally focused on a single white marble headstone emblazoned with the name "SMITH." Other elements, such as three additional markers behind and to the right, several trees in the distance, and a white chain boundary to the left, are softly and slightly out of focus. The headstones in these photographs function much like the street signs in Montezuma, Main Street, facing East, Plains, and Plains. In the sense that they require a very specific set of knowledge (of a family or family history), the linkages these photographs establish reinforce the "unalterable" nature of what they mark. This is also a 


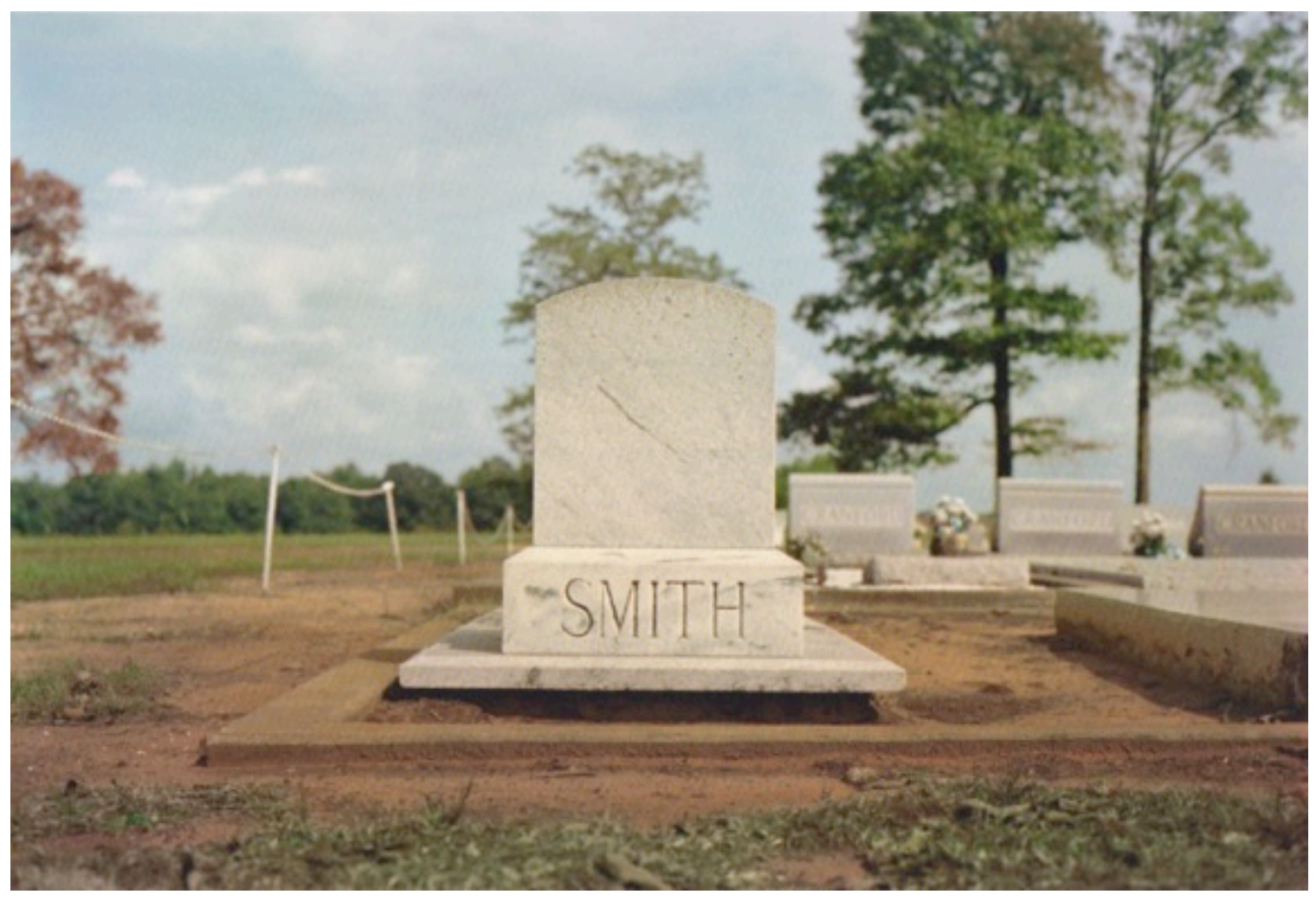

Figure 25. William Eggleston, near Friendship, 1976, Chromogenic color print, 10 1/4 x 15 in. 
double marking: the photograph is a physical trace just as the tombstone is a physical trace of the dead. 


\section{CHAPTER V}

Eggleston's engagement with the processes of land marking and path making pulls from issues that have their source in photography's earliest circumstances. Benjamin explains that an early use of photography was the creation of portraits of the dead. Such objects were more than representations but inheritors of the physical essence of their subjects. ${ }^{170}$ Benjamin approximates this surrogacy to the "cult value" of certain objects such as religious icons that was located not just in their being visible or graspable but their discrete existence in the world. ${ }^{171}$ Tintype portraits often shared in this cultic function because their own tangible presence overlapped with that of their depictions and effectively prolonged life in a different material form. ${ }^{172}$ Either as surrogate or substitute, the photograph facilitated the persistence of both the living and dead as coextensive entities. This function was further aided by the photograph's effect on the viewer. Benjamin described this as "an irresistible urge to search such a picture for the tiny spark of contingency" that could bind the viewer, photograph, and its subject together. ${ }^{173}$ Such binding could be both figurative and literal. According to Barthes, such a spark is a potentially physical phenomenon, an interaction of the rays of light projected between object, camera, print, and viewer. ${ }^{174}$ The punctum and its piercing effects have a counterpart in the emanations of light that contribute to the physical and chemical 
processes that form photography's material ground. These same rays of light also facilitate vision. Viewer and photographic subject are concretely tied together through the same processes.

Perhaps less a survey than an attempt to make something absent appear or reappear, Eggleston's photographs provide a site for the negotiations of visibility. So many of the photographs in Election Eve engage with the past both as concept and its concrete manifestations. Many things seem faded or covered in a patina: old, decrepit, and decayed. ${ }^{175}$ Even the grave marker shown in Plains, though it appears relatively clean and bright, indicates life in the past tense. The photograph itself is no different and is only capable of being that-has-been. Even as an object encountered in the present the photograph is inextricably bound to the past as soon as it is shot. But this is all a consequence of the general face photographs present to the world, the function of which is to make their content immediately present. In most cases and for most viewers Election Eve's places are only places, and not one's place. Even for Eggleston, this part of the South was not necessarily his South. Even he could be considered an outsider in and around Plains. This is wholly unlike Christenberry's lifetime dedication to his own personal Southern environs in Hale County, AL. Christenberry decided to begin his own project because he personally recognized what was in the photographs of Evans's and James Agees's 1941 book Let Us Now Praise Famous Men. ${ }^{176}$ Yet the buildings he came to photograph year after year were much more personal than they could been to Evans. Sites like the family homestead in Stewart, the Palmist Building in Havana Junction (Figure 26), once a general store operated by Christenberry's great-uncle, and even the nearby graveyards, essentially share the same place with him. 

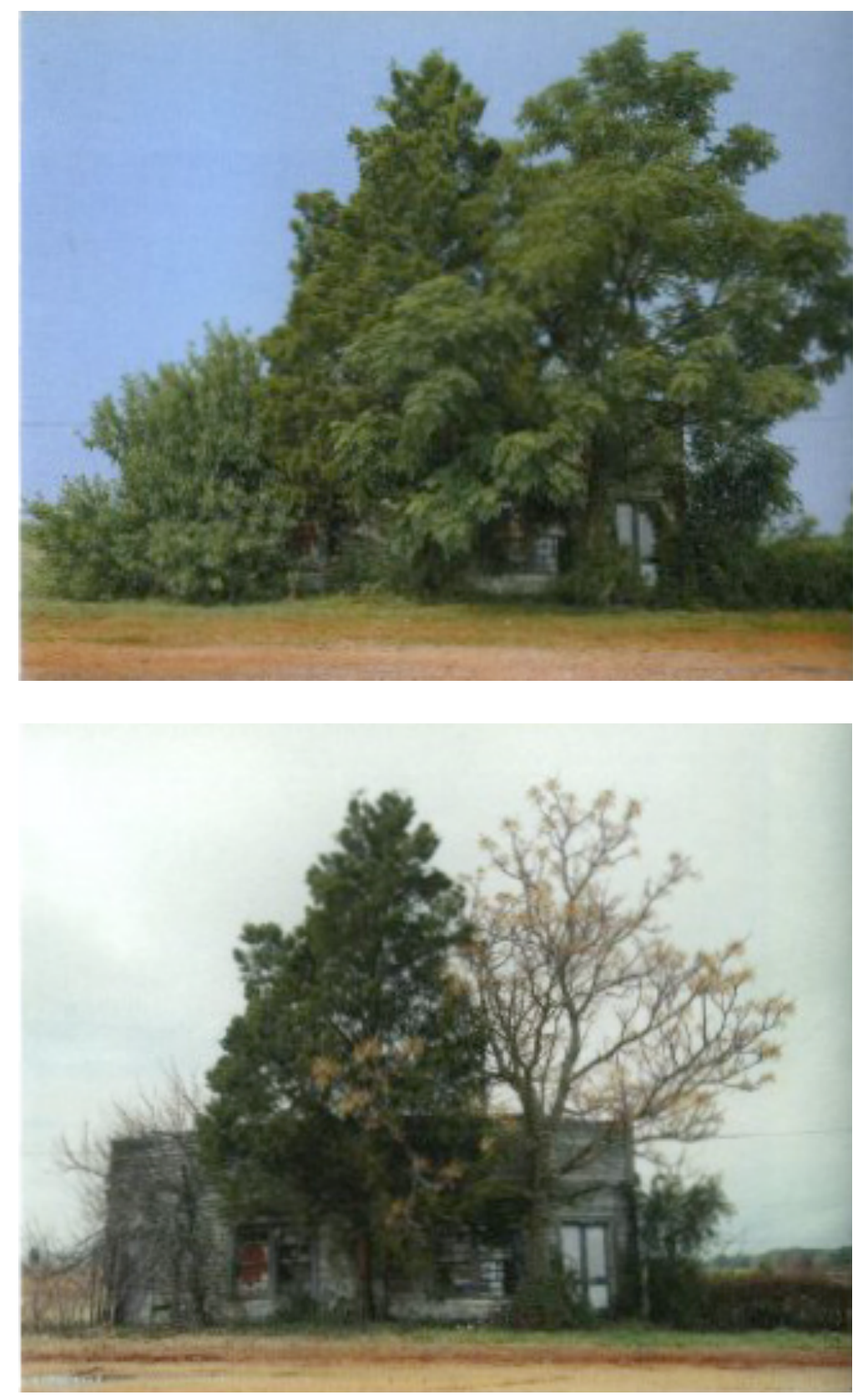

Figure 26. William Christenberry, Palmist Building (Summer), Havana Junction, Alabama, 1980, Digital print from camera negative, 4 x 5 in.

William Christenberry, Palmist Building (Winter), Havana Junction, Alabama, 1981, Digital print from camera negative, $4 \times 5$ in. 
It is all the more paradoxical when this type of deeply personal stake is measured against the lack of firm patent and latent readings in Election Eve's photographs. The "SMITH" headstone could be anyone's, and such a common name is potentially both anonymous and deeply specific. By all accounts this was someone's relative, but the general viewer is only able to connect to the generalization of death provided by this photograph and its preclusion of a more pointed reference. The precarious balance between the general and specific ${ }^{177}$ in Election Eve shatters as the initially-forged connections between Eggleston's experience and the experience of his photographs turn out to be inconsequential. If these forms are instead simulations of reality, ${ }^{178}$ Eggleston's photographs ultimately torpedo attempts made to codify them, like Fonvielle does, as a "sketchbook portrait" or any kind of portrait. ${ }^{179}$ While this doesn't preclude it from being its own reality, Election Eve's failures seriously undermine the grand tradition of photography's attempts to be anything but that-has-been

By this measure Election Eve is best served when the extent of such failures are properly taken into account. The forms I have analyzed have a common role in how they construct reality (through discourse). Concepts like family, social class, identity of person or place, mapped boundary, these and a plethora of others represent realities that meaningfully exist only through the aggregation of statements and the interventions of discourse. When Bourdieu speaks of the photograph's role in the "solemnization" of family life, he identifies this as a ceremonial role. ${ }^{180}$ Photography is perhaps the principle formal means through which an abstract reality becomes a concrete one. ${ }^{181}$ By this measure, nothing is real unless it is documented, corroborated with evidence, verified and crosschecked, or run through into a system of values. To enter into discourse through the 
transformation of forms is to also pass from material to meaning. Yet this translation is never assured. When it fails photographs are left behind like orphans. In this case, they can only point to themselves as feeble proof that they are real.

If failure is inevitable then the photograph's isolation is key to its presence in the world. Would it really be possible to follow Eggleston and retrace the same path through Sumter County he had undertaken in October 1976? I had intended to try and find out. I wanted to go and see for myself. But while planning my trip I realized that Google Maps furnished something very similar to what I had encountered when I read through Election Eve for the first time. Here was yet another view of the world composed by individual images strung together with enough of a whiff of reality that it was easy to accept it as the real thing. So instead of piling into my small SUV and driving the 530 miles and eight hours to Plains, I zoomed in and out of the cities of Sumter County on my computer screen where I found the same place names that I found in Election Eve's titles and on its map. Yet further identification with the book's place was nearly impossible except for the few pictures that offered the appropriate legible corroboration. Photographs such as Main Street, facing East, Plains, Montezuma, High School, Plains (Figure 27), or Lutheran Church, Plains (Figure 28) contained landmarks that could potentially attest to something beyond the limits of their own frames. Their counterparts could be located. There were the pale red bricks of the old Plains High School, now the Jimmy Carter National Historic Site, and there was the bright red door of the St. Andrews Lutheran Church. But even then they remained isolated points with little relation to what might be around them. Beyond these few I was at a loss. Where could I go and what could I see? How could I 


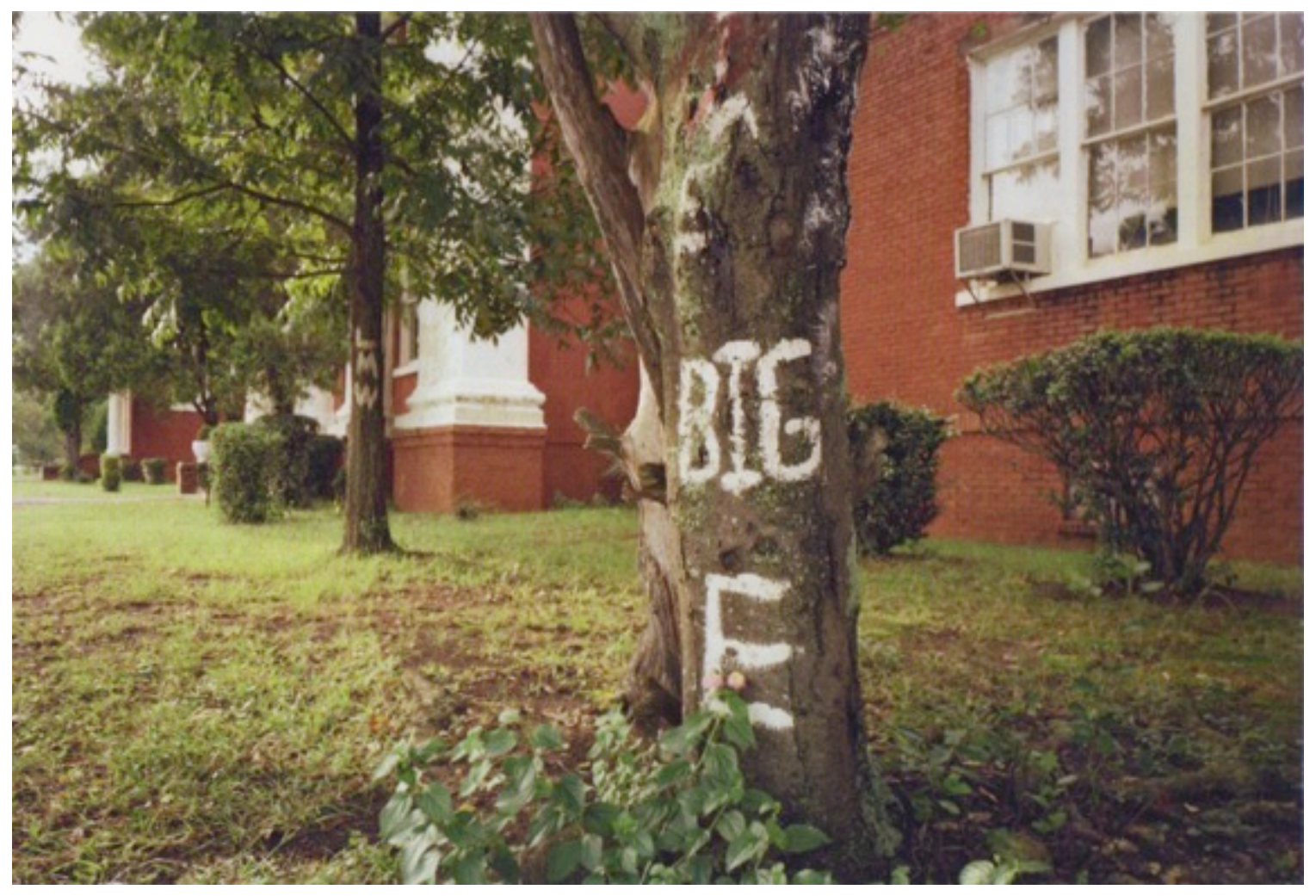

Figure 27. William Eggleston, High School, Plains, 1976, Chromogenic color print, 10 $1 / 4 \times 15$ in. 


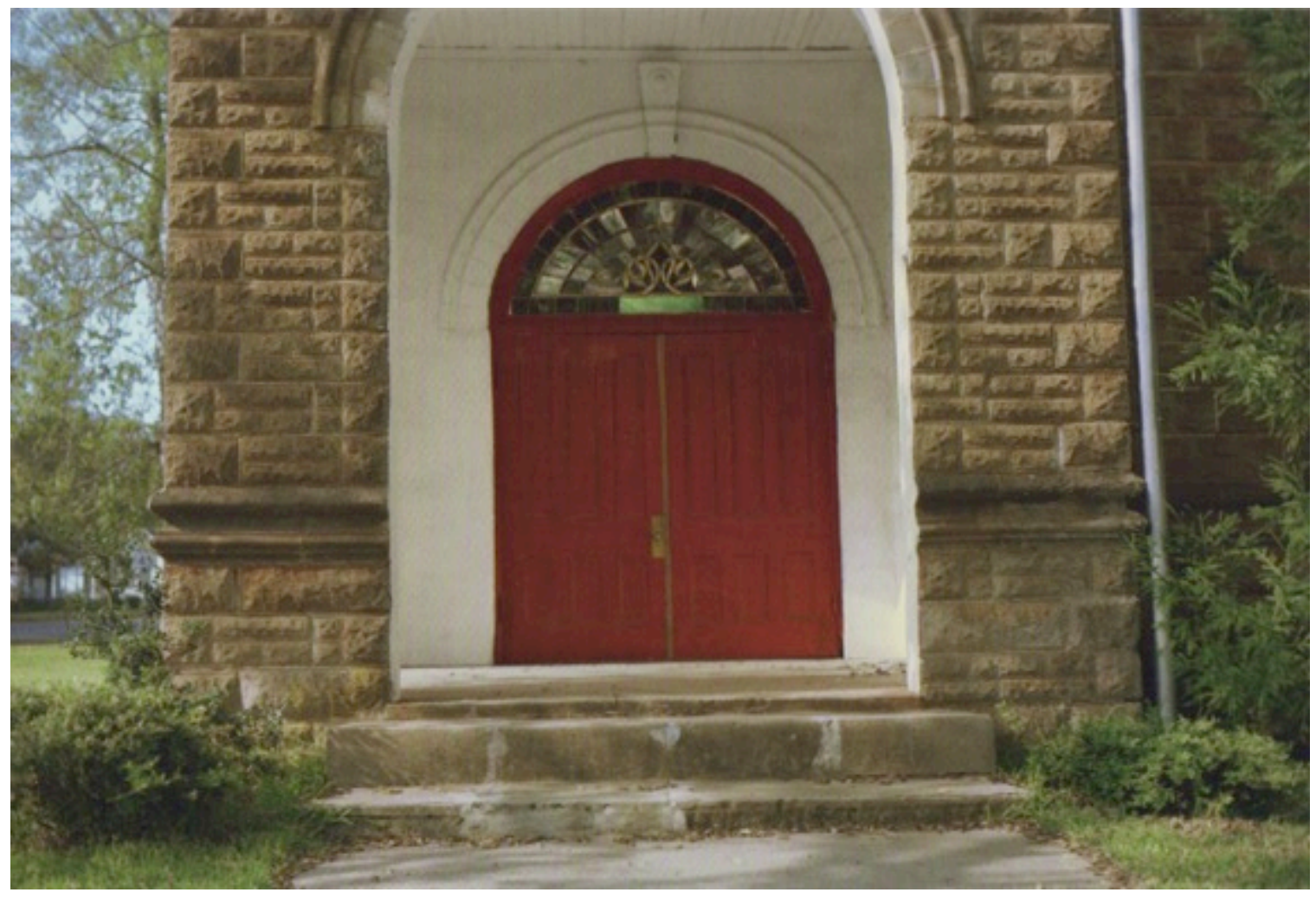

Figure 28. William Eggleston, Lutheran Church, Plains, 1976, Chromogenic color print, $101 / 4 \times 15$ in. 
truly know Election Eve was real or still is? Even formulated within Google Maps, the places I saw on my screen were hardly the Sumter County of Eggleston's photographs.

The irony that Election Eve's parts fail to come together as a cohesive whole is what ultimately makes its photographs legible. Baltz remarks that other Eggleston pictures often led to frustration for viewers and critics. This frustration was aimed at their failure to be statements with any relevance outside of a very narrow set of concerns such as their immediate composition, colors, and aesthetic. ${ }^{182}$ This elucidates Eggleston's own assertion that his practice is driven solely by the way that certain things like colors appear in his photographs. ${ }^{183}$ Yet the claim seems to go against the majority of uses photographs have been put towards and from which Eggleston's appear to leech. Perhaps Eggleston's photographs cannot be reliably trusted except for what they are. Eggleston has called his photographs "part of a novel I have in progress," an indication that they are more fictional than anything else. ${ }^{184}$ They verify no external place except of a few photographs that hint at the strict locality of streets and intersections. Pictures such as Main Street, facing East, Plains and Montezuma display local street names yet they are legible only in the context of the immediate surroundings within their photographic frame and bear little resemblance to those streets and highways the book's map displays. ${ }^{185}$ These few ties are almost incidental. Many more photographs of streets and roads that appear in Election Eve remain anonymous. As a whole the photographs are so weakly attached to their mapped location that the specifics their mapped places cannot be easily pinpointed and therefore retread via a map. The connections are instead strongest between those photographs that share affinities with each other absent their attributed roles as documents. This is not to say that they are the only ties, but they most effectively stake 
their claim to a world through those sites where the photographs can gather and be gathered. These sites happen to be the photographs themselves. Within Election Eve there is more than one Sumter County visible: titles, maps, and photographs form the constitute parts. But where they ultimately fail to overlap elucidates their existence as a complex web of often-disparate realities.

The difficulty within these objects stems from the ways form and function are initially bundled together to signify in a certain way. Here signification is first possible as meaning is exchanged between the collaboration of things that do not directly resemble one another. This also allows for larger cultural systems to be maintained even as their individual signs and objects might change. ${ }^{186}$ Barthes's punctum can likewise be formulated through the process of bundling. As he explains in reference to James Van der Zee's Family Portrait (1926) (Figure 29), his own punctum was a detail that reached into the memory and emotion of his own experience. Barthes explains that the necklace of the woman standing on the right reminded him of something his aunt had also worn. ${ }^{187}$ While Barthes essentially deems these objects the same thing through the influence of the punctum, Margaret Olin points out that they are far from identical. In the realm of memory, such mistakes in identification can facilitate the transfer of the punctum from the level of an object or subject within a photograph to the level of the photograph itself. ${ }^{188}$ According to Olin, the affinity is not between the two pieces of jewelry, but on the level of photographic representation that combines and transforms the jewelry, the figures, and the rectangular black-and-white portrait scene, into an experience and sign of a discrete reality. ${ }^{189}$ While it is not clear that Barthes actually considered these pieces of jewelry identical, Van der Zee's photograph reminded him of a photograph of his 


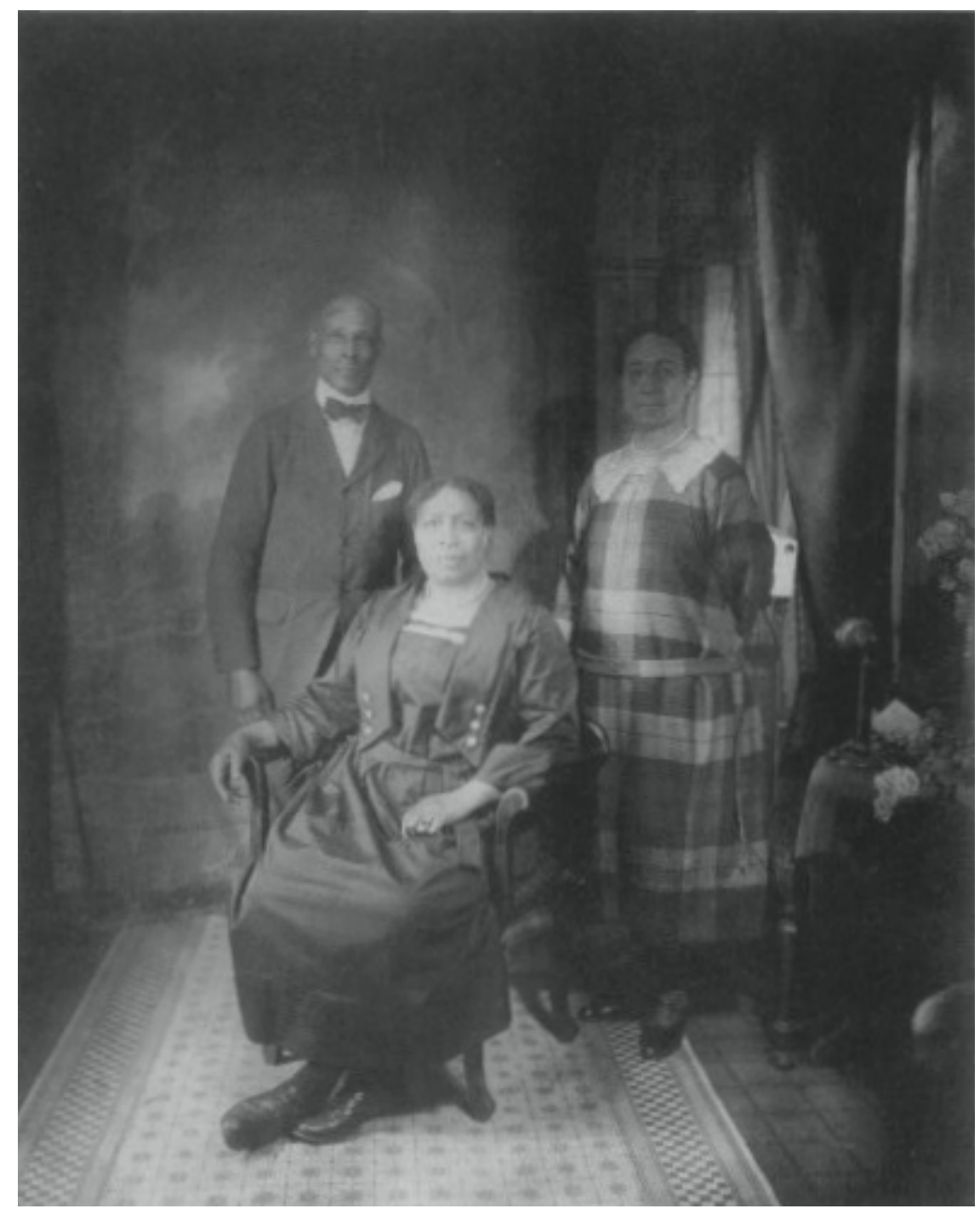

Figure 29. James Van der Zee, Family Portrait, 1926, Gelatin silver print, 7 1/2 x 9 5/16 in. 
grandparents and aunt (Figure 30) that featured the same figures (one man and two women) in very similar poses in a similar portrait studio. ${ }^{190}$ Memory often finds a material form in photographs, a phenomenon that allows the photograph to play substitute or surrogate in addition to reality's tool. Because it is ceded the operation of remembrance, the photograph takes on other qualities of memory, such as its ability to fail or to be untrustworthy.

The experience of looking at photographs is intimately tied to both the content and experience of memory. Once I sat with my mother in front of my laptop and used Google Maps to try to find the places she had lived as a child. In South Miami Beach, FL, her grandmother's house was now the location of a shopping mall parking lot. In nearby Davie, we were unable to find the small tract and farmhouse with its horse and cow that she remembered so vividly. Google Maps could only provide the traces of these places. Even then its panoramic image of the world is constantly remade and refigured as new traces are layered upon old traces. One of the ways Election Eve seems so real despite all of its jaggedness is that Eggleston's photographs resist the neat duplication of reality's experience and instead present something vague and mutable more along the lines of memory. The links forged are not between the photograph and the far-off place it depicts but between the viewer who directly encounters the photograph. My father's childhood home in West Palm Beach, FL, finally found through Google Maps, wasn't how he remembered it either. The back porch was gone and a new driveway had been added. Yet the old place was still in his mind. His parent's bedroom looked out over the covered front parlor next to the stairs that creaked whenever he went up them. His grandfather had built the house that existed for him, not the pixelated simulation constructed by cameras 


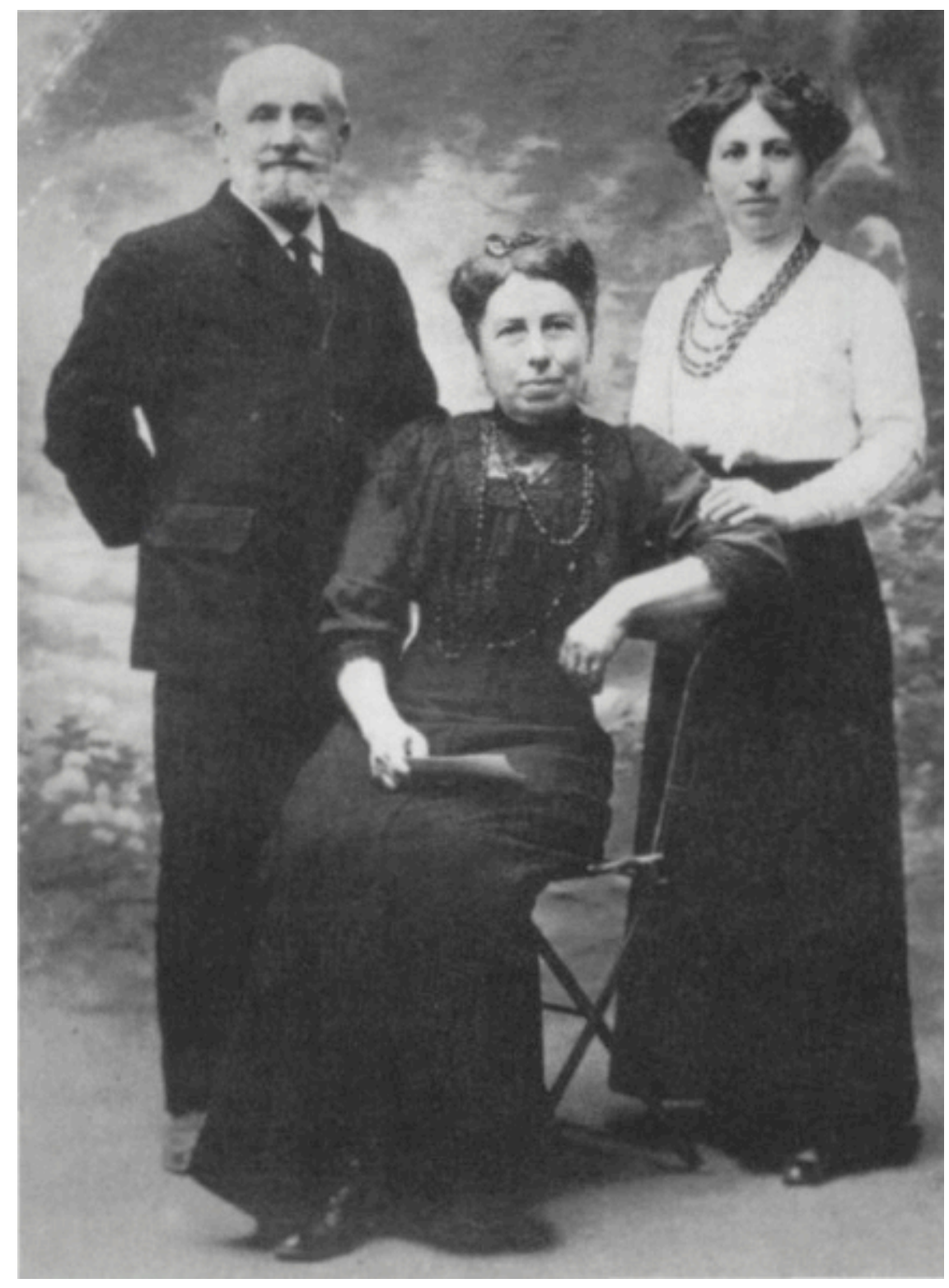

Figure 30. Unknown photographer, Berthe and Léon Barthes and their daughter Alice, n.d. 
and images that appeared on the screen of my laptop. Memory and map were not congruent, and there was now more than one place where that house stood.

The inconsistencies of forms, discourses, and experiences lie at the core of Election Eve's photographs. On the corner of Oglethorpe and Drayton as seen through Google Maps, many of the same elements can still be seen as in Montezuma. Yet, exact duplication is not quite possible. Despite the perceived seamlessness of Google Maps and its own sense of totality, it is actually more formally akin to Election Eve than the reality of the places either of them depict. The reverse is also true. Election Eve shares an affinity with the highly systemized and overtly constructed experience provided through Google Maps. Despite contemporary struggles within digital and virtual media over their putative ephemerality, mediation is a still key element in the experience of the digital photograph. Where before this took the form of the print, book, or newspaper, or other material thing, the screen is now the primary means of looking at pictures. Even virtual reality, though it attempts to replicate the operations of the visual field, remains limited to an experience through an apparatus not unlike the screen. Virtual reality follows much the same principle as stereo photography, a technology that appeared more that one hundred sixty years before it. Both employ masks that cover their artificiality behind discrete and complete visual experiences rather that barefaced attempts to imitate reality. After all, vision is also seamless and total, or so it seems. Yet reality's effect must still be total in order for it to truly work.

Like the operations of memory, to copy the function and effects of vision is to copy its blind spots. This is not just its physical limitations but is also the futile expectation that vision is inherently trustworthy. While the digital and the virtual attempt 
to minimize or mask the mediating object in order to create new models of perception, they still fall into the same traps that have made other forms of representation subservient to the form and content of visible reality. As Baudrillard declares, "the territory no longer precedes the map" and the simulacrum, the copy with no original, has the capacity to be as real or more real than reality ever was. ${ }^{191}$ As soon as a mass of photographs could stand in for reality's presence, questions of truth and falsehood in the realm of representation became irrelevant. At its core, this is what the photograph has done since its inception. The photograph produces nature better than Nature or God could create. ${ }^{192}$ The essence of the photograph has been its ability to cover for the real, to make seeing the thing itself unnecessary. To collect together photographs and arrange them in meaningful ways does not just make the objects themselves a distinct and real experience but constructs a reality that is potentially more ideal and that resides outside of time. When successful, the reality effect is no longer an effect, but a quality inherent to the photograph itself.

As the photograph replaces the model with itself it takes on the perfection of its content as the new model for reality. Perfection, in this sense fixity, is an important conceptual element of the archive, photo album, and travel guide. The rigid resistance to external wills transforms the photograph from a neutral document to an idealized reality in the form of a closed, measurable, and totally knowable system. This "systematicity" as John Tagg defines it has been a means to balance the idealism of the survey with practical problems such as storage and utility. ${ }^{193}$ The book is one means to accomplish such systemization. It is immediate, practical, and provides the futurity of already articulated knowledge ready to be deployed and redeployed. Additionally, the book is a symbolic 
manifestation of knowledge's "ideal architecture." Tagg identifies the "'modern vertical file," often used in bureaucratic archives, as another such manifestation. These forms literally and figuratively buffet knowledge between a finite and controllable set of boundaries in order to submit reality and transform it according to their own models. ${ }^{194}$

Because Election Eve is a book of photographs, it conforms to these idealized structures and their attempts to mold reality. I have demonstrated how fragmented its volumes are, how the presumptions of time and place do not offer much in the way of corroboration. But to this same extent Election Eve reaches for a different kind of idealization than is normally expected of its forms. Its idealization is referential to its own presence and to the specific and personal experience of Eggleston in October of 1976. The additional references provided are hardly appropriate for what the photographs depict or what information they might provide when arranged and viewed in sequence. Despite the decrepitude of many of the things shown in the photographs, "real" time seems to melt away and leaves only its traces. Ambiguous daylight and rain puddles speak more of time's cyclical repetitions than a calendar's date or a clock's digits. Cohesive systemization also fails as the pages are turned from photograph to location and map. Election Eve is ultimately neither model nor copy, but a separate and specific construction that can only reliably show itself and the internal interplay between its photographs, their subjects, and the interventions of the viewer's added experience. Context plays an important role in Election Eve, one that exists on the levels of content and form. Before last year, its photographs have only been available outside of their original context. They have appeared by themselves or alongside other pictures, but always stripped of the original book's milieu. Even then, photographs like Snak Shak, 
Montezuma (Figure 31), retain a self-enclosed and self-determined character. While it is the lone interior photograph in Election Eve, Snak Shak, Montezuma doesn't depart from the characteristics that help bind its cohorts together. Softly lit by the same diffuse light, the pale buff and yellow back wall of the room, shot at an oblique angle, cuts across the space and makes the dimensions of the room difficult to parse. Along this wall, a row of tables recedes from right to left of the frame, each one with a different color and style of vinyl-upholstered chair. Like many of its counterparts, there are no figures present in the photograph. In addition to this overt absence the tables are clean and tidy and it is unclear if and when they have last been used. Two bunches of plastic-wrapped artificial flowers hang on the wall above the two visible tables are; one bunch is hangs straight while the other hangs crookedly. There is no indication of time relative to the space, no way to know why there are no people where one would expect them to be, no way to glean any context other than what can be seen within the picture's frame. The anonymity of the space is hardly dispelled by its titular location, and the map that identifies the town of Montezuma indicates only that it can be found somewhere in Georgia along Highway 49. A reality external to this particular photograph exists only by virtue of its appearance among other photographs, or by virtue of its own enclosed frame. The photograph is a microcosm of its limitations as document or record. It represents the shortcomings of the photograph's bounded systemization that persist even when they collected, organized, and made to mean something. ${ }^{195}$

Eggleston hints at the limitations of both photograph and mass of photographs in other places as well. False starts and non-sequiturs crop up when the viewer attempts to connect the photographs to the external world. There is heightened anxiety about these 


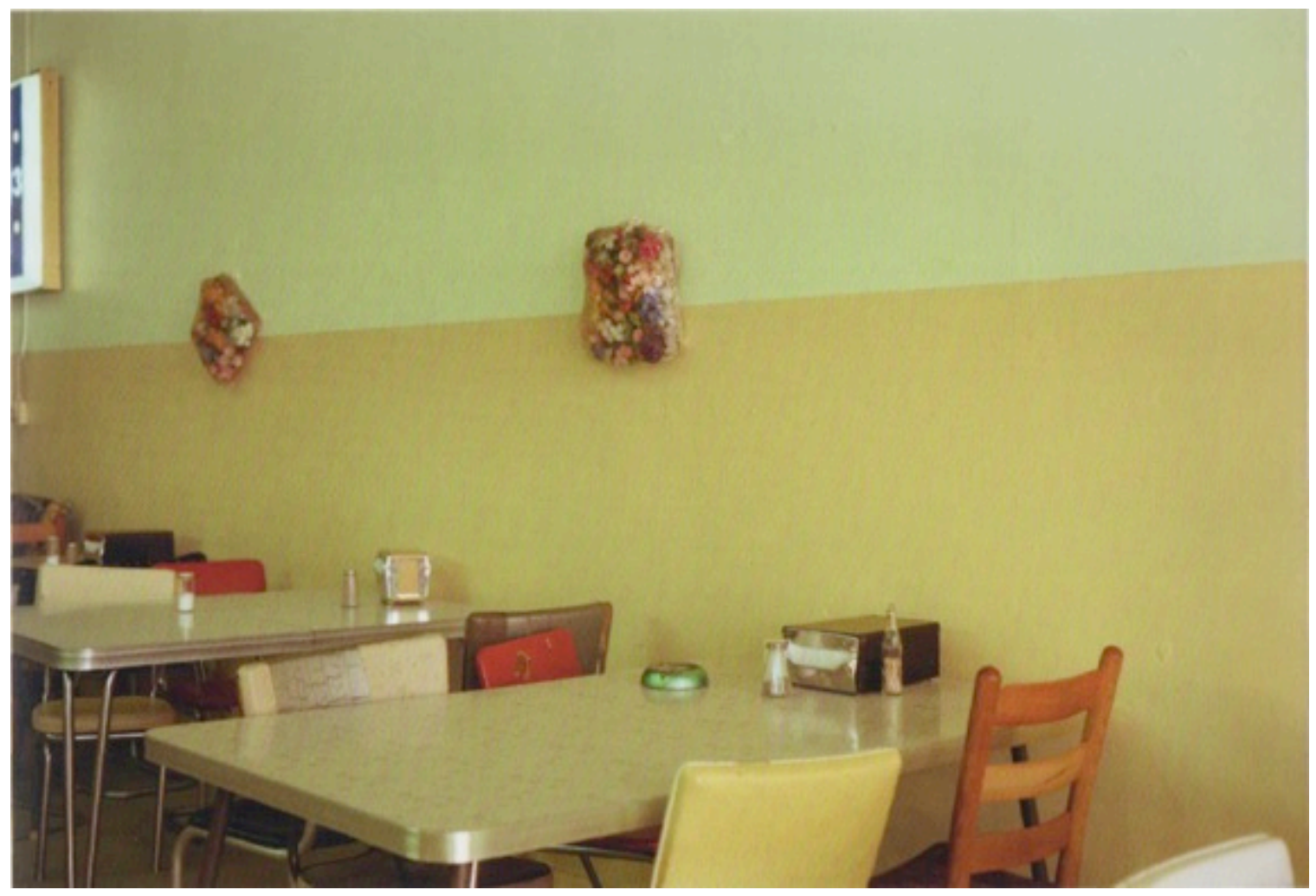

Figure 31. William Eggleston, Snak Shak, Montezuma, 1976, Chromogenic color print, 10 1/4 x 15 in. 
disconnects when the initial anonymity of the photographs comes up against the reality of knowable (and mappable) places. The landmarks don't match up to what is being projected onto them; they don't truly adhere to the apparent reality of the forms they inhabit. Instead, the photographs seem more isolated than they are integrated into the world. This is the reality effect's return to itself and the emptiness of its signification. If Eggleston's practice is one of fiction, the significance of his photographs does not stem from a world of facts and figures but from their togetherness as something more than their individual depictions. As Bathes declares, these fragments state, "we are the real," nothing more and nothing less than the signs of reality itself. ${ }^{196}$ What this reality actually is remains up for grabs. 


\section{CHAPTER VI}

The quality of the realness deployed in Election Eve owes much to the "scripts" embedded in the forms of book and photograph that guide and inform how they are used and understood. ${ }^{197}$ They provide a sense of coherence and wholeness, even if these things stem from mistaken identification, misuse, or misappropriation. ${ }^{198}$ Eggleston's play on what photographs are expected to do and what they actually do (at least in this situation) contributes to a complex and nuanced exchange between appearance and reality. It seems ironic that a photograph such as Snak Shak, Montezuma was included at all in a book apparently dependent on external points like terrain, landscape, and architecture that are definitive elements of geography and topography. As the lone photograph of an interior space it breaks up Election Eve's stretches dominated by mossy trees, blue skies, asphalt and dirt roads, and old brick and clapboard façades. It is the fifty-ninth photograph in the book yet the first hint that this Sumter County might be something farther removed, specific only to what the pictures themselves manage to muster. It is the first thread that remains conspicuously loose. It doesn't tie back into the neat and well rehearsed narratives and "cultural totalit[ies]" that inform how these objects and locations are habitually read and understood. ${ }^{199}$ As Keane points out, culture is not informed by a "code book or set of rules in [people's] heads," and for this reason objects are ceded

some autonomy in their functions. ${ }^{200}$ Yet there is an expectation that they conform to 
certain norms of use and interpretation, to behave as discourse and its forms have behaved in the constitution of intelligible and meaningful statements. This is one reason Snak Shak, Montezuma is so jarring in sequence. The photograph's contribution is wholly uneven and possibly inappropriate to what Election Eve initially seems to be and do. In essence, the photograph doesn't follow the scripts that enable what it presents to be legible. From this single image spreads the futility of bringing to Election Eve's other ninety-nine photographs the expectation that they will speak in a certain way or to a certain purpose.

This is a burden that Eggleston's work has inherited and is therefore far from unique to his photographs. De Salvo calls pictures in their basest form dyes applied to sheets of paper, ${ }^{201}$ but the things known to the viewer as photographs are much more than their requisite materials, a concept that Eggleston's own insistence to the contrary might actually allude to. ${ }^{202}$ In another context, Ritchin sees the capacity for physical and emotional empathy within a stark distinction between digital and physical film media; the fact that the human body, natural landscape, and photographic print can age and decay establishes a sense of camaraderie and mutual subjectivity. ${ }^{203}$ As Barthes claims, the burden of death is the burden of the photograph. ${ }^{204}$ But Election Eve does more than inform and participate in mortality. Instead, Eggleston plays on the entire condition of meaningful experience, the seemingly endless and cyclical repetitions that appear as boundaries, structures, and discourses and are applied to the real in order to make sense of it. Snak Shak, Montezuma is not just another photograph closed in by its rectangular frame, closed in by the rectangular page, bounded within its volume's covers, and nestled in box. It envelops the viewer in its reality as well. 
This interaction between the viewer and photograph has the capacity to break free of the external constraints placed upon it. As Latour asks, should we actually "take literally what it means for an interaction to frame, to structure, or to localize?"205 Eggleston's repeated assertion that his photographs are not really about what they depict and therefore lack outside meaning may instead be an attempt to recast them without or at least distanced from photography’s historical and material contingencies. ${ }^{206}$ Or, his photographs represent a very complex gathering of historical, social, and artistic issues whose dynamically continue to be assessed and reassessed. That Election Eve appeared at such a moment when color photography's status as art was not yet assured and speaks to the very nebulous existence of the book and the singular risk taken by its creators. ${ }^{207}$ It has until very recently been far from accessible, a stark contrast to the populism of many of its "inartistic sources." Weski remarks that Eggleston's approach follows the trajectory of photographers like Arbus, Friedlander, and Winogrand, especially in his engagement with the immediacy and spontaneity of the snapshot. ${ }^{208}$ Winogrand once stated that his strategy was to "photograph to find out what something will look like when photographed." ${ }^{209}$ Eggleston's claim is something else entirely. He is instead concerned with what the photograph itself looks like as a photograph. ${ }^{210}$ Even if his comments about subject matter being inconsequential to his photographs are, as Kukielski describes them, "disingenuous and strategic" 211 and ultimately dismissible, the fact remains that the physical presence of the photograph plays a pivotal role in Eggleston's relationship to his own work. Not simply art objects of museums, galleries, and photo books that follow the conventions of the amateur snapshot, Eggleston's photographs have a tangible and immediate importance that goes beyond (or before) the signifying action of their content. 
Election Eve's own historical importance is tied to the persistent economic and theoretical problems in which photographs have long been embroiled as things in the world. The diversity of the life of the photograph plays a significant role in Election Eve's lack of resolution.

Even in their relative isolation, the pictures in Election Eve imply an expectation that they will not always remain so. Branching into and out of the panoply of tables and chairs of Snak Shak, Montezuma, the threads between the photographs of Election Eve tie, retie, and untie as the possibilities of meaning continue to emerge and recede. Just like their content, the forms these photographs take ultimately remain open because photography has had and continues to have a tenuous connection to the subjectivity and objectivity of reality. Flowing through the prints, the content also oozes with the anticipation of future meanings and uses. Blank façades, prominently and straightforwardly captured in photographs such as old jail, Smithville (Figure 32) and railroad depot, Plains (Figure 33) are like surfaces that wait to be repurposed or renewed. Conversely they can be left in their decrepit states to continue to crumble and decay. The relative emptiness of the photographs, the lack of human figures in all but a few pictures, does not feel empty at all. Instead they anxiously anticipate the future. When human figures do appear, such as in Mississippi (Figure 34) and Main Street, facing East, Plains, they appear in the distance or in the shot's periphery, mid-stride toward some unseen destination outside what the camera can see. Others are barely glimpsed in cars, sometimes little more than blurs. These photographs come across as pieces of some as-ofyet unknown journey. Despite the rigidity of the prints, the tension between frame and subjects is hard to ignore. The viewer likewise shares this anxiety. Even the more serene 


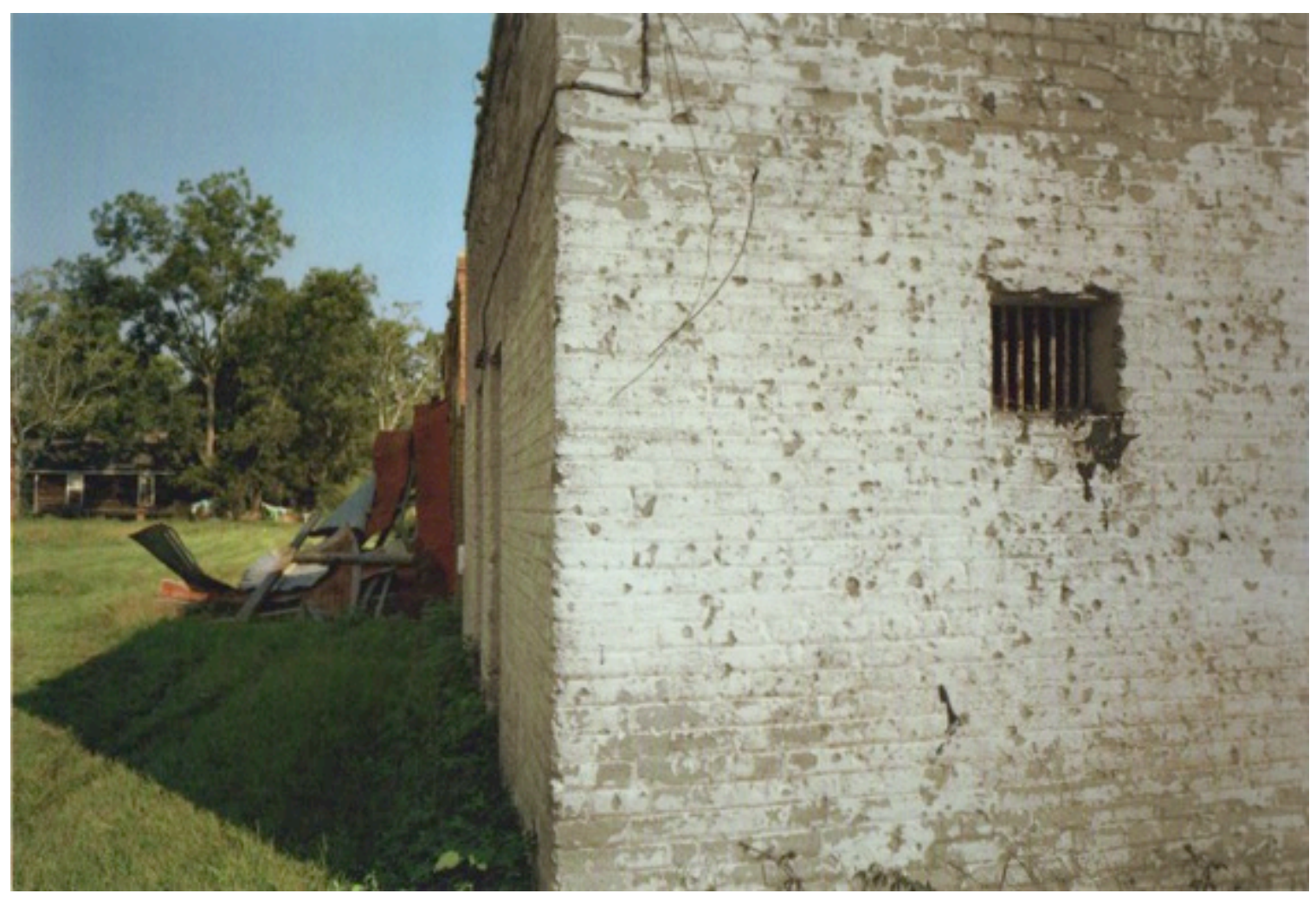

Figure 32. William Eggleston, old jail, Smithfield, 1976, Chromogenic color print, 10 1/4 $\mathrm{x} 15$ in. 


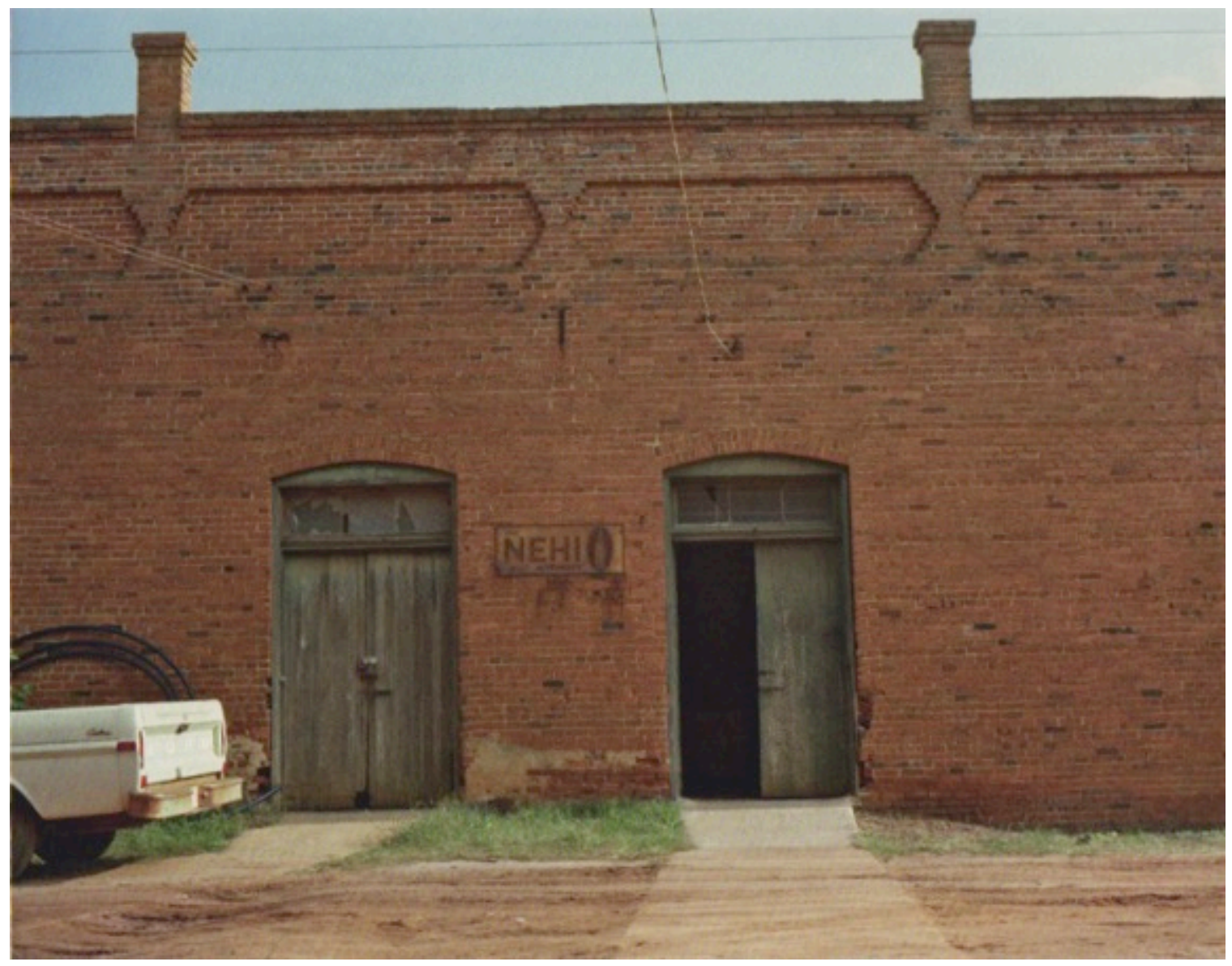

Figure 33. William Eggleston, Plains, 1976, Chromogenic color print, 10 1/4 x 13 in. 


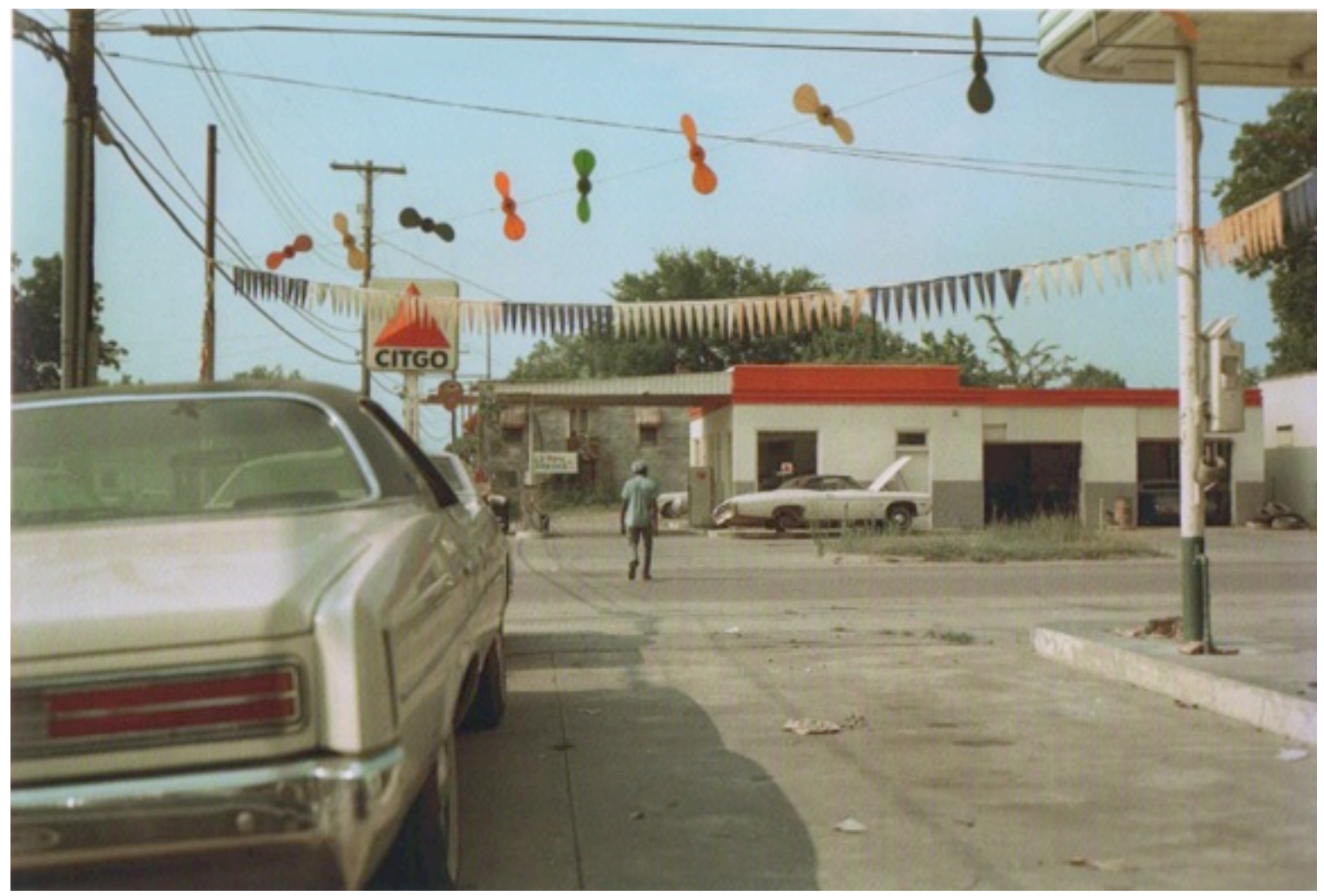

Figure 34. William Eggleston, Mississippi, 1976, Chromogenic color print, 10 1/4 x 15 in. 
photographs in Election Eve push and pull at their edges with a restless energy. In this way, Eggleston capitalizes on his photographs's tendency to fail their assumed aims. In Andersonville (Figure 35), a spotted white dog lounges in a slightly overgrown yard of an old-looking house with a sagging tin roof. Like some of the cars Eggleston captured moving along streets and road, the dog's head is blurred, caught in motion. What was at first glance a single frozen moment is broken into a web of possibilities. A shadowed human figure looks out from an open screened window and likewise implies that the scene has not yet reached its payoff, if such a scene or payoff exist in a straightforward narrative sense. This photograph is wholly predicated on its futurity. Its open-endedness allows for still undefined uses and relationships to emerge. This almost reverses the historical paradigm of photography, a technology so often used to make things visible in order to bind them within various systems of control. Even Eggleston's chosen title hints at something whose full force and importance is still unknown and may never be know. The photographs themselves are likewise suspended on the cusp of complete meaning or legibility. This opens them up, in their functions as objects and signs, to what Latour terms a "reversal in the direction of influence." ${ }^{212}$ The flow is no longer from photographer and camera to reality and photograph, but between photograph and viewer, from past and present to future. This allows the photograph to do more than describe, record, or stand as evidence. Instead, a whole spectrum of causality takes shape through which the objects can "authorize, allow, afford, encourage, permit, suggest, influence, block, render possible, [or] forbid" in the course of forging new connections with the viewer. ${ }^{213}$ Both viewer and photograph contribute to the construction of these new connections. In both abstract and concrete ways, Election Eve is an offer to the viewer to 


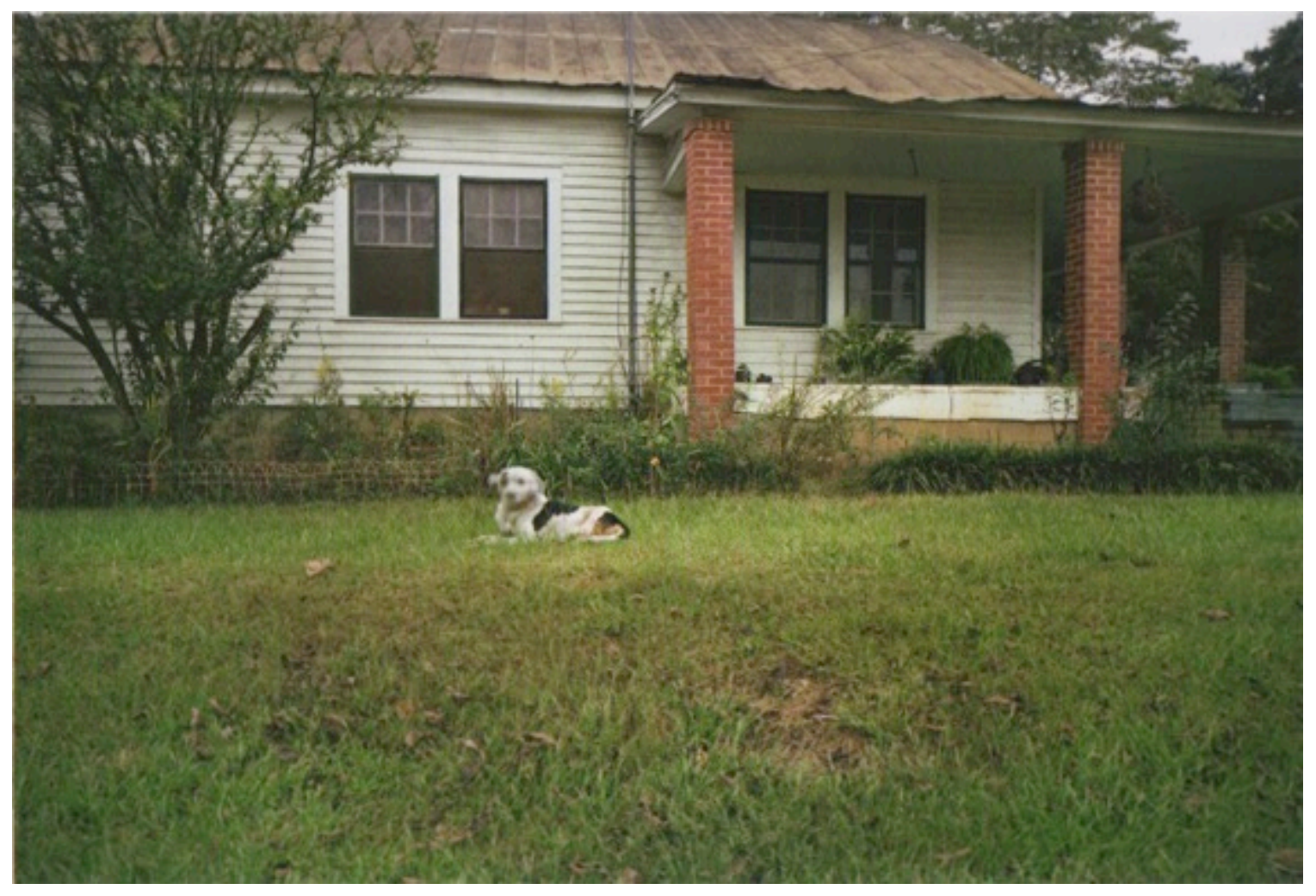

Figure 35. William Eggleston, Andersonville, 1976, Chromogenic color print, 10 1/4 x 15 in. 
consider what outcomes its photographs might yet produce if any are to be produced at all, even in the face of the rigid assumptions its forms carry embedded within them. The emptiness of things like bleachers, parking lots, and diners look toward not only the eventuality of usage but also redefinitions of their very spaces. The photographs themselves, as they persist and continue to be inserted into new contexts, likewise remain open to further transformations.

The futurity of these objects offers possibility not just in the way they are perceived as signs, but the ways new contingencies might also contribute to entirely new uses. Not only must signs be understood as signs and objects as objects, but the ways in which these understandings change can also affect future transformations of settled knowledge into other forms. ${ }^{214}$ Election Eve was recently republished for the first time since 1977. The book is now widely available to an exponentially larger audience. It is no longer only within the purview of private and museum collections. The totality of Election Eve as a book offers a material experience that differs greatly from its fragmented individual appearances. Meaning and value are likewise contingent upon the spaces in which they are encountered and the other objects appear along side them. Yet the new edition of Election Eve is itself formally distinct from its predecessor. The book is linen rather than leather bound, uses differently textured paper, is combined into a single volume, and its dimensions are greatly reduced. No longer separately mounted cprints, the photographs are instead printed directly onto the book's glossy pages using a four-color offset process. The original prints, now faded and yellowed with age, have their colors "restored." The titles are provided on each opposite page rather than listed at the end. 
While these differences may seem obvious or ultimately incidental, they represent an entirely new set of ideological contingencies that can provide new conceptualizations of Election Eve as both a discrete object and sign. If anything, Election Eve's material form, newly replicated but further transformed, enters into new discursive fields as it is reassessed both on its own and in relation to other forms, subjects, and histories. As both an incitement and invitation, the continued rearticulation of the role of these materialities within an ever-expanding network of knowledge and experience might very well reconceptualize the role of the photographic object and book and their connections to reality. With the further passage of books and photographs into digital formats, the role of the object itself and what might be embedded in new configurations and technologies also presents new possibilities, and potential challenges, to the relationships between resemblance and truth, knowledge and discourse. Even so, the reality of Election Eve remains rooted in the objects that can be seen, touched, interacted with, and directly experienced. Eggleston has created something and someplace that does not simply follow behind reality but warrants exploration in and on its own terms. 


\section{NOTES}

${ }^{1}$ While Election Eve was his first bound book of prints, Eggleston published a portfolio of fourteen loose prints in 1974 with Harry Lunn in Washington D.C.

${ }^{2}$ Lloyd Fonvielle, Preface to William Eggleston, Election Eve (Göttingen, Germany: Steidl, 2017), n.p.

${ }^{3}$ Publisher's colophon, in Eggleston, Election Eve, n.p.

${ }^{4}$ Unless otherwise noted, references in regards to the book and its photographs as individual objects come from the 1977 edition. Fonvielle's preface originally appeared in the 1977 edition while Chubb's afterword was written for the 2017 edition. Because of quality and availability, reproductions of the photographs in Election Eve featured here come from the 2017 edition.

${ }^{5}$ Chubb's claims credit for this structural resemblance. See Caldecott Chubb, Afterword to Eggleston, Election Eve, n.p.

${ }^{6}$ One significant difference between the 1977 and 2017 editions is the latter provides titles on the pages opposite each photograph in addition to listing them at the end of the book.

${ }^{7}$ Bruno Latour, Reassembling the Social: An Introduction to Actor-Network-Theory (Oxford: Oxford University Press, 2005), 79.

${ }^{8}$ Roland Barthes, "The Reality Effect," in The Rustle of Language, trans. Richard Howard (Berkeley, CA: University of California Press, 1989), 142.

${ }^{9}$ Webb Keane, "Signs Are Not the Garb of Meaning: On the Social Analysis of Material Things," in Materiality, ed. Daniel Miller (Durham, NC: Duke University Press, 2005), 190. 
${ }^{10}$ Thomas Weski, “'I Can’t Fly, But I Can Make Experiments,"” in Elizabeth Sussman and Thomas Weski, William Eggleston Democratic Camera: Photographs and Video, 1961-2008, Exhibition catalog (New York: Whitney Museum of American Art, 2008), 7.

${ }^{11}$ Bruno Latour, "Why Has Critique Run out of Steam? From Matters of Fact to Matters of Concern," Critical Inquiry 30 (2004): 233.

${ }^{12}$ Latour, "Why Has Critique Run out of Steam?," 233.

${ }^{13}$ Roland Barthes, "The Discourse of History," in The Rustle of Language, 139.

${ }^{14}$ Latour, Reassembling the Social, 118.

${ }^{15}$ Weski, “'I Can’t Fly, But I Can Make Experiments,"” 7.

${ }^{16}$ Weski, “I Can’t Fly, But I Can Make Experiments,” 7.

${ }^{17}$ Keane, "Signs Are Not the Garb of Meaning," 186.

${ }^{18}$ Keane, "Signs Are Not the Garb of Meaning," 186.

${ }^{19}$ Latour, "Why Has Critique Run out of Steam?," 231.

${ }^{20}$ Jane Bennett, Vibrant Matter: A Political Ecology of Things (Durham, NC: Duke University Press, 2010), 5.

${ }^{21}$ Barthes, "The Discourse of History," 139.

${ }^{22}$ Barthes, "The Discourse of History," 140.

${ }^{23}$ Barthes, "The Reality Effect,” 142.

${ }^{24}$ For example, Election Eve's chromogenic color prints represent a common type of print used by both amateur and professional photographers.

${ }^{25}$ Lewis Baltz, "KONSUMERTERROR: Late-Industrial Alienation,” Aperture, no. 96 (Fall 1984): 6. 
${ }^{26}$ John Szarkowski, Introduction to William Eggleston's Guide, Exhibition catalog (New York: Museum of Modern Art, 1976), 6.

${ }^{27}$ Weski, “'I Can’t Fly, But I Can Make Experiments,"” 16.

${ }^{28}$ Tina Kukielski, "Closed on Tuesday," in Sussman and Weski, William Eggleston Democratic Camera, 258.

${ }^{29}$ Fonvielle, Preface to Eggleston, Election Eve, n.p.

${ }^{30}$ Baltz, “KONSUMERTERROR,” 6.

${ }^{31}$ Baltz, “KONSUMERTERROR,” 6.

${ }^{32}$ Weski notes that Eggleston's 1976 exhibition was actually preceded by five other exhibitions of color photographs at MoMA alone, the earliest in 1943, including Marie Cosindas: Polaroid Color Photographs in 1966. Eggleston's was framed as the first because John Szarkowski considered it good publicity to do so. Even then, it was not until the 1970 s that the widespread use of color film began to supplant earlier notions regarding its appropriate use in art photography. Walker Evans famously called color photography "vulgar," but added that vulgar subject matter required the equivalent vulgarity of color film. Ironically, Evans became fascinated with the possibilities of the Polaroid towards the end of his life. This interest in color film can be linked to a friendship with the photographer William Christenberry who himself worked exclusively in color. See Weski, “'I Can’t Fly, But I Can Make Experiments,”’ 19n41.

${ }^{33}$ Weski, “'I Can’t Fly, But I Can Make Experiments,"” 9.

${ }^{34}$ Weski, “'I Can’t Fly, But I Can Make Experiments,"” 9.

${ }^{35}$ Weski, “'I Can’t Fly, But I Can Make Experiments,"” 12. 
${ }^{36}$ Donna De Salvo, "Every Picture," in Sussman and Weski, William Eggleston Democratic Camera, 255.

${ }^{37}$ De Salvo, "Every Picture," 255.

${ }^{38}$ Geoffrey Batchen, "Ectoplasm: Photography in the Digital Age," in Over Exposed: Essays on Contemporary Photography, ed. Carol Squires (New York: The New Press, 1999), 18.

${ }^{39}$ John Howell, "Sight Unseen in Plain Sight," in Aperture, no. 165 (Winter 2001): 14.

${ }^{40}$ William Eggleston, in Mark Haworth-Booth, "William Eggleston: An Interview," History of Photography 17, no. 1 (Spring 1993): 51.

${ }^{41}$ Howell provides an anecdote in which Eggleston, unsure about whether a certain photograph of his was taken horizontally or vertically, is inclined to display it in the way that appears most sensible according to the print, regardless of whether or not it is correct to the original shot. See Howell, "Sight Unseen in Plain Sight," 14.

${ }^{42}$ Keane, "Signs Are Not the Garb of Meaning," 183.

${ }^{43}$ Keane, "Signs Are Not the Garb of Meaning," 184.

${ }^{44}$ Szarkowski curated an exhibition in 1978 titled "Mirrors and Windows: American Photography Since 1960" in which he attempted to model contemporary photographic practice as a binary continuum between the poles of internal and external, or the concerns of photographer and the world. Ultimately this analysis left little if any room for the mediating role of the photograph or the viewer. See John Szarkowski, Introduction to Mirrors and Windows American Photography since 1960, Exhibition catalog (New York: The Museum of Modern Art, 1978), 25. 
${ }^{45}$ Jessica McDonald, “An Honest Sense of the Place: Reconsidering John Szarkowski’s The Face of Minnesota," Photography \& Culture 1, no. 2 (November 2008): 215.

${ }^{46}$ Keane, "Signs Are Not the Garb of Meaning," 186.

${ }^{47}$ Keane, "Signs Are Not the Garb of Meaning," 185.

${ }^{48}$ Barthes, "The Discourse of History," 127.

${ }^{49}$ Roland Barthes, Camera Lucida, trans. Richard Howard (New York: Hill and Wang, 1980), 76.

${ }^{50}$ Barthes, “The Discourse of History," 139.

${ }^{51}$ Keane, "Signs Are Not the Garb of Meaning," 190.

${ }^{52}$ Keane, "Signs Are not the Garb of Meaning," 188.

${ }^{53}$ Keane, "Signs Are not the Garb of Meaning," 186.

${ }^{54}$ Semiotic ideology is also important to definitions of reality. These ideologies do more than inform how signs are rendered but also the connections between signs and their causal impact on the world. This is what Latour refers to when he declares that "the common world has still to be collected and composed" in a concrete way after reality and its effect have been accounted for through the abstract involvement of discourses. Latour is less concerned with reality as singular phenomenon than as a legible "unity" of subjects and actants. See Latour, Reassembling the Social, 118.

${ }^{55}$ Barthes, Camera Lucida, 93.

${ }^{56}$ Alexander Gardner, Gardner's Photographic Sketch Book of the War (Washington D.C.: Philp \& Solomon’s, 1866), n.p.

${ }^{57}$ Latour, Reassembling the Social, 79.

${ }^{58}$ Szarkowski, Introduction to William Eggleston's Guide, 12. 
59 "When Alfred H. Barr, Jr., first saw a selection of slides from this series in 1972 he observed - surprisingly but in fact accurately — that the design of most of the pictures seemed to radiate from a central, circular core. In time the observation was relayed to Eggleston, who replied, after a barely perceptible hesitation, that this was true, since the pictures were based compositionally on the Confederate flag." This may or may not have been a joke on Eggleston's part. Szarkowski, Introduction to William Eggleston's Guide, 11.

${ }^{60}$ Michel Foucault, The Archaeology of Knowledge, trans. A. M. Sheridan Smith (New York: Vintage Books, 1972), 129.

${ }^{61}$ Foucault, The Archaeology of Knowledge, 130.

${ }^{62}$ Fred Ritchin, After Photography (New York: W. W. Norton \& Company, 2009), 11.

${ }^{63}$ Siegfried Kracauer and Thomas Yevin, "Photography," in Critical Inquiry 19, no. 3 (Spring 1993): 433.

${ }^{64}$ Allan Sekula, "The Body and the Archive," in The Contest of Meaning: Critical Histories of Photography, ed. Richard Bolton (Cambridge, MA: The MIT Press, 1989), 347.

${ }^{65}$ Usually closely aligned with theories and deployments of eugenics.

${ }^{66}$ John Tagg, The Disciplinary Frame: Photographic Truths and the Capture of Meaning (Minneapolis: University of Minnesota Press, 2009), 28.

${ }^{67}$ Sekula, "The Body and the Archive," 374.

${ }^{68}$ Sekula, "The Body and the Archive," 374. 
${ }^{69}$ Not to be confused with so-called "straight" documentary photography, "documentarystyle" photographs were intended to stress authorial authority while retaining an appeal to truth derived from the purported neutrality of the documentary form. See Weski, “I Can’t Fly, But I Can Make Experiments,"” 7.

${ }^{70}$ There are a number of projects that straddle the categories of art and archival photography. These include surveys of the Depression-era United States done by Evans, Dorthea Lange, Russell Lee, Gordon Parks and others under the leadership of Roy Stryker and Farm Security Administration (previously the Resettlement Administration), Frances Benjamin Johnston's Carnegie-funded survey of Southern vernacular architecture in the 1930s, or Bernd and Hilla Becher's career-spanning occupation with large-scale industrial buildings. Others include the government and artist supported work of photographers Charles Marville and Eugene Atget in Paris in the latter half of the nineteenth century to document the city's various and changing views or August Sander's ambitious goal of documenting every person in Germany in the 1920s and 1930s. In regards to Atget, Molly Nesbit has made an elucidating distinction in the purposes and uses of the "specific archive" and that of the "general idea of the archive." Such a distinction can be traced to the fact that a variety of governmental institutions, artists, historians, antiquarians, and others appropriated the same photographs Atget took in service of the construction of their own specialized bodies of knowledge. These bodies rarely overlapped in meaningful ways despite the use of identical documents. See Molly Nesbit, Atget's Seven Albums (New Haven, CT: Yale University Press, 1992), 17. ${ }^{71}$ Ritchin uses Szarkowski's terminology. Fred Ritchin, Bending the Frame: Photojournalism, Documentary, and the Citizen (New York: Aperture, 2013), 9. 
${ }^{72}$ Ritchin, After Photography, 21.

${ }^{73}$ Nesbit, Atget's Seven Albums, 6.

${ }^{74}$ Pierre Bourdieu, Photography: A Middlebrow Art, trans. Shaun Whiteside (Cambridge:

Polity Press, 1990), 27.

${ }^{75}$ Walter Benjamin, "Little History of Photography," in Selected Writings Volume 2:

1927-1934, trans. Rodney Livingstone and Others, eds. Michael W. Jennings, Howard

Eiland, and Gary Smith (Cambridge, MA: The Belknap Press of Harvard University

Press, 1999), 508.

${ }^{76}$ Benjamin, "Little History of Photography," 508.

${ }^{77}$ Benjamin, "Little History of Photography," 512.

${ }^{78}$ Benjamin, "Little History of Photography," 510.

${ }^{79}$ Benjamin, "Little History of Photography," 510.

${ }^{80}$ Justo Navarro, "What Remains of Time: The Present and Ex-Votos," in William

Christenberry, Exhibition catalog (New York: D. A. P., 2013), 44.

${ }^{81}$ Possibly the same camera Christenberry used for his early reference photographs. See

William Christenberry and Susanne Lange, William Christenberry: Working From

Memory (Göttingen: Steidl, 2008), 14.

${ }^{82}$ Bourdieu, Photography, 19.

${ }^{83}$ Bourdieu, Photography, 30.

${ }^{84}$ Italo Calvino, "The Adventure of a Photographer," in Difficult Loves, trans. William Weaver, Archibald Colquhoun, and Peggy Wright (New York: Harcourt Brace Jovanovich, 1984), 222.

${ }^{85}$ Calvino, "The Adventure of a Photographer," 229. 
${ }^{86}$ Navarro, "What Remains of Time," 47.

${ }^{87}$ Christenberry found it difficult or impossible to repeatedly photograph from the same positions in some cases. A sequence that featured an asphalt-papered barn was altered altered when a pre-fabricated building was erected in the spot where Christenberry usually stood to take his shots. The building was removed several years later and Christenberry was once again able to take up his usual vantage point.

${ }^{88}$ In the sense that time advances forward or from left to right. In addition, Western written languages are generally read left to right and books in those languages proceed from left page to right page. This reinforces the assumption that time has a linear, progressive, and directional format and discourse likewise carries this built-in cardinal bias.

${ }^{89}$ Tiffany Bell, “Eve Sonneman's Progressions in Time,” Artforum 18, no. 2 (1978): 57.

${ }^{90}$ Sally Eauclaire, The New Color Photography (New York: Abbeville Press, 1981), 110.

${ }^{91}$ Barthes, Camera Lucida, 92.

92 Barthes, Camera Lucida, 93.

${ }^{93}$ Barthes, Camera Lucida, 93.

${ }^{94}$ Ritchin, Bending the Frame, 52.

95 Jacques Derrida, Copy, Archive, Signature: A Conversation on Photography, ed. Gerhard Richter, trans. Jeff Fort (Stanford, CA: Stanford University Press, 2010), 43.

${ }^{96}$ Barthes, Camera Lucida, 93.

${ }^{97}$ Ritchin, Bending the Frame, 49.

${ }^{98}$ Barthes, Camera Lucida, 5. 
${ }^{99}$ Dean MacCannell, The Tourist: A New Theory of the Leisure Class (Berkeley, CA: The University of California Press, 1999), 23.

${ }^{100}$ MacCannell, The Tourist, 24.

${ }^{101}$ Bourdieu, Photography, 19.

102 This is to say nothing about the way film replicates the chronological movement of time through the quick succession of individual frames. But because film is composed of frames, perhaps it could be classified under the umbrella of the photographic slideshow. ${ }^{103}$ Benjamin, "Little History of Photography," 507.

${ }^{104}$ Meaning "loafer" or "stroller."

${ }^{105}$ Benjamin notes that Louis Daguerre was an apprentice in the studio of panorama painter Pierre Prévost and operated his own panorama before his involvement with photography. Benjamin, "Daguerre, or the Panoramas," in The Writer of Modern Life: Essays on Charles Baudelaire, ed. Michael W. Jennings, trans. Howard Eiland, Edmund Jephcott, Rodney Livingston, and Harry Zohn (Cambridge, MA: The Belknap Press, 2006), 34 .

${ }^{106}$ Benjamin, "The Paris of the Second-Empire in Baudelaire," 68.

${ }^{107}$ Benjamin, "The Paris of the Second-Empire in Baudelaire," 68.

108 The rise of the middleclass.

${ }^{109}$ Though it is certainly true of photographic objects, these are not quite "commodities" in the Marxist sense. Rather, I am concerned with a more general semiotic valuation of commodities as signs beyond the value provided through the means of their production. See MacCannell, The Tourist, 21.

${ }^{110}$ Benjamin, "The Paris of the Second-Empire in Baudelaire," 86. 
${ }^{111}$ Bourdieu, Photography, 35.

112 Bourdieu, Photography, 35.

${ }^{113}$ Roland Barthes, "Myth Today," in Mythologies, trans. Richard Howard and Annette Lavers (New York: Hill and Wang, 2012), 136.

${ }^{114}$ Barthes, "The Blue Guide," in Mythologies, 136.

${ }^{115}$ Barthes, "The Blue Guide," 134.

${ }^{116}$ Jean Baudrillard, Simulacra and Simulation, trans. Sheila Faria Glaser (Ann Arbor, MI: The University of Michigan Press, 1994), 1.

${ }^{117}$ Barthes, "The Blue Guide," 137.

${ }^{118}$ Weski, “'I Can’t Fly, But I Can Make Experiments,”” 8.

${ }^{119}$ Bourdieu, Photography, 37.

${ }^{120}$ Barthes, “The Blue Guide," 136.

${ }^{121}$ Latour, Reassembling the Social, 189.

${ }^{122}$ Suffixes that refer to the small, medium, and large scale ratios produced through the action of zooming in and out on an image. See Latour, Reassembling the Social, 188.

${ }^{123}$ Latour, Reassembling the Social, 188.

${ }^{124}$ Latour, Reassembling the Social, 185.

${ }^{125}$ Jorge Luis Borges, “On Exactitude in Science," in Collected Fictions, trans. Andrew Hurley (New York: Viking, 1998), 345.

${ }^{126}$ Borges, “On Exactitude in Science,” 345.

${ }^{127}$ Umberto Eco, “On the Impossibility of Drawing a Map of the Empire on a Scale of 1 to 1," in How to Travel with Salmon and Other Essays, trans. William Weaver (New York: Harcourt Brace \& Company, 1994), 96. 
${ }^{128}$ Eco, "On the Impossibility of Drawing a Map of the Empire on a Scale of 1 to 1," 106.

${ }^{129}$ Latour, Reassembling the Social, 188.

${ }^{130}$ Latour, Reassembling the Social, 189.

${ }^{131}$ Keane, "Signs Are Not the Garb of Meaning." 188.

${ }^{132}$ James Collins, "DAVID ASKEVOLD, John Gibson Gallery; STEPHEN SHORE, Light Gallery; MARK COHEN, Light Gallery; BILL DANE, The Museum of Modern Art; JOHN MARMARAS, Studio Show,” Artforum 12, no. 7 (1974): 76.

${ }^{133}$ Collins, "STEPHEN SHORE, Light Gallery," 76.

${ }^{134}$ Marta Dahó, "Stephen Shore: The Paradoxes of Transparency,” in Stephen Shore, Exhibition Catalog (New York: Aperture, 2014), 16.

${ }^{135}$ Marta Dahó, “Stephen Shore,” 16.

${ }^{136}$ This description might not be literal. It is difficult to parse any coherent route by matching the procession of titles to the map. See Fonvielle, preface to Election Eve, n.p. ${ }^{137}$ Barthes, Camera Lucida, 5.

${ }^{138}$ There is no documentation about the duration of Eggleston's trip to Sumter County. ${ }^{139}$ Eggleston has been quoted in relation to his early black and white photographs that he “couldn't imagine doing anything more than making a perfect fake Cartier-Bresson." He continues to work in in a similar vein and claims to shoot each subject only once. By this measure, each photograph is uniquely representative of its respective moment in time. See Stanley Booth, "Triumph of the Quotidian," in Sussman and Weski, William Eggleston Democratic Camera, 266.

${ }^{140}$ Sonneman's titular reference to Cartier-Bresson's The Decisive Moment, for example. ${ }^{141}$ Latour, Reassembling the Social, 189. 
${ }^{142}$ Latour, Reassembling the Social, 189.

${ }^{143}$ Barthes called this use of small seemingly inconsequential details in a narrative “insignificant notation.” See Barthes, "The Reality Effect," 142.

${ }^{144}$ Bruno Latour, Emilie Hermant, and Patricia Reed, Paris: Invisible City, Bruno Latour, 2004, http://www.bruno-latour.fr/virtual/EN/index.html. 14 October 2017.

${ }^{145}$ Latour, Hermant, and Reed, Paris: Invisible City.

${ }^{146}$ Latour, Hermant, and Reed, Paris: Invisible City.

${ }^{147}$ Keane, "Signs Are Not the Garb of Meaning," 188.

${ }^{148}$ The notion that the link between a sign's components, the signifier and signified, and the sign's link to its referent are arbitrary and therefore independent of material contingencies. Keane argues that such a notion is not sensitive to the historical and social conditions that create, reinforce, weaken, or sever those links and that represent a more nuanced relationship between signs and objects. Though such links are not "natural," they are not inconsequential either. See Keane, "Signs Are Not the Garb of Meaning," 183. ${ }^{149}$ Keane, "Signs Are Not the Grab of Meaning," 188.

${ }^{150}$ Benjamin, "The Work of Art in the Age of its Technological Reproducibility," in The Work of Art in the Age of its Technological Reproducibility and Other Writings on Media, ed. Michael W. Jennings, Brigid Doherty, and Thomas Y. Levin, trans. Edmund Jephcott, Rodney Livingstone, Howard Eiland, and Others (Cambridge, MA: The Belknap Press, 2008), 23.

${ }^{151}$ Benjamin, "The Work of Art in the Age of its Technological Reproducibility," 23.

${ }^{152}$ Benjamin, "The Work of Art in the Age of its Technological Reproducibility," 23. 
${ }^{153}$ A process Benjamin describes as "extracting sameness from what is unique." In this way, unique objects can be progressively transformed into more generic signs for a more general class of things, a broader classification of representation as a material form, and more broadly as image. This allows a diverse set of objects to exhibit the same characteristics despite differences in appearance. See Benjamin, "The Work of Art in the Age of its Technological Reproducibility," 24.

${ }^{154}$ Latour, Hermant, and Reed, Paris: Invisible City.

${ }^{155}$ Latour, Hermant, and Reed, Paris: invisible City.

${ }^{156}$ In French, Cheminement. This term has specific implications in the fields of topography in the context of the precise paths measured between points by a theodolite, a tool that can accurately determine changes in distance or elevation. Latour, Hermant, and Reed, Paris: invisible City.

${ }^{157}$ Latour, Hermant, and Reed, Paris: Invisible City.

${ }^{158}$ As "units of content" measured according to "units of discourse." See Barthes, "The Discourse of History," 133-4.

${ }^{159}$ Barthes, "The Blue Guide," 136.

${ }^{160}$ It is unclear who made the decision to include the map and display the titles in a separate list. While Chubb claims to have been responsible for most of the book's design decisions, Eggleston was probably consulted. See Chubb, Afterword to Eggleston, Election Eve, n.p.

${ }^{161}$ Barthes, Camera Lucida, 73.

${ }^{162}$ Margaret Olin argues that Barthes did not actually possess the specific photograph he described. The vague terms of its description and use in Barthes's critical discussion 
provides enough evidence to question whether or not the "Winter Garden Photograph" was real or just a theoretical construction that served to billet Barthes's ideas. However, the assertion that Barthes made concerning the "indifference" anyone else would have in relation to such a photograph generally makes this a moot point. See Margaret Olin, “Touching Photographs: Roland Barthes's 'Mistaken' Identification,” Representations 80 (2002): 99-118.

${ }^{163}$ Barthes, Camera Lucida, 73.

${ }^{164}$ Barthes, Camera Lucida, 73.

${ }^{165}$ Barthes, Camera Lucida, 28.

${ }^{166}$ Barthes, Camera Lucida, 26.

${ }^{167}$ Barthes, Camera Lucida, 53.

${ }^{168}$ Barthes, Camera Lucida, 27.

${ }^{169}$ Barthes, Camera Lucida, 81 .

${ }^{170}$ Benjamin, "The Work of Art in the Age of its Technological Reproducibility," 27.

${ }^{171}$ Benjamin, "The Work of Art in the Age of its Technological Reproducibility," 25.

${ }^{172}$ Benjamin, "The Work of Art in the Age of its Technological Reproducibility," 27.

${ }^{173}$ Benjamin, "Little History of Photography," 510.

${ }^{174}$ Barthes, Camera Lucida, 81.

175 The prints in the 1977 edition display similar effects. While this is not reflected in the reproductions I have provided, it is important to note.

${ }^{176}$ Christenberry initially recognized the place names presented in the book. With the help of family members who still lived in Hale County he identified the people who had had their names changed by Evans and Agee for the book's publication. This included 
Elizabeth Tingle who had appeared under the pseudonym "Margaret Ricketts." See Christenberry and Lange, William Christenberry: Working From Memory, 14.

${ }^{177}$ Or the studium and punctum.

${ }^{178}$ Or discrete realities.

${ }^{179}$ Fonvielle, Preface to Election Eve, n.p.

${ }^{180}$ Bourdieu, Photography, 19.

${ }^{181}$ Bourdieu, Photography, 19.

182 Baltz, “KONSUMERTERROR,” 6.

${ }^{183}$ De Salvo, "Every Picture," 254.

${ }^{184}$ Nathan Kernan, “William Eggleston’s ‘Democratic Photography’ The Los Alamos

Project," Art on Paper 6, no. 2 (November-December 2001): 67.

${ }^{185}$ Strictly speaking, the designations that appear on Election Eve's maps actually disconnect the photographs from the reality of place as a mapped and mappable location. ${ }^{186}$ Keane, "Signs Are Not the Garb of Meaning," 188.

${ }^{187}$ Barthes, Camera Lucida, 53.

${ }^{188}$ Olin, "Touching Photographs," 107.

${ }^{189}$ Olin, "Touching Photographs," 107.

${ }^{190}$ Olin, "Touching Photographs," 106.

${ }^{191}$ Baudrillard, Simulacra and Simulation, 1.

192 This was one early argument against the use and development of photographic technology. Critics such as Charles Baudelaire bemoaned photography as the death knell of art because it perfectly replicated rather than built upon nature's example. See Benjamin, "Little History of Photography," 527. 
${ }^{193}$ John Tagg, The Disciplinary Frame, 220.

194 The same could be said of the computer servers that have replaced the vertical file. Both rely on systematicity to enable the storage and retrieval of data. This is visible in the way computer files are named, indexed, and visualized. For example, folders displayed in a computer interface usually use a representation of a paper file folder as an icon. See Tagg, The Disciplinary Frame, 223.

195 Tagg, The Disciplinary Frame," 224.

${ }^{196}$ Bathes, "The Reality Effect," 148.

${ }^{197}$ Latour notes that this can take the form of regulations, instruction manuals, or official guidelines that "make [objects] talk" through specific, sanctioned, or licensed use. However, for many objects this is simply a process instilled and reinforced through habitual social or cultural use rather than literal prescription. See Latour, Reassembling the Social, 79.

${ }^{198}$ Latour, Reassembling the Social, 79.

${ }^{199}$ Keane, "Signs Are Not the Garb of Meaning," 188.

${ }^{200}$ Keane, "Signs Are Not the Garb of Meaning," 188.

${ }^{201}$ De Salvo, "Every Picture," 255.

${ }^{202}$ Fiction, created with bits of reality, would be apt way to categorize Eggleston's photographs. However, this runs into more difficulties. Perhaps these photographs instead belong to the institutions of the "realistic novel" or "historical literature." Barthes describes these as forms that seek plausibility in the details of setting that in turn signify them as real rather than the logical procession of a narrative. See Barthes, "The Discourse of History," 139. 
${ }^{203}$ Ritchin, Bending the Frame, 49.

${ }^{204}$ Barthes, Camera Lucida, 96.

${ }^{205}$ Latour, Reassembling the Social, 194.

206 "I want to make a picture that could stand on its own, regardless of what it was a picture of. I have never been the least bit interested in the fact that this was a picture of a blues musician or a street corner or something." See Howell, "Sight Unseen in Plain Sight," 14.

${ }^{207}$ Chubb comments that the financial risk of publishing Election Eve was very real. Gardner's Sketchbook was similar in this respect as well. Alexander Gardner went bankrupt after the book's release because the market for such an object was largely nonexistent. See Chubb, Afterword to Eggleston, Election Eve, n.p.

${ }^{208}$ Weski, “'I Can’t Fly, But I Can Make Experiments,"” 7.

${ }^{209}$ Gene Thornton, "The New Photography: turning traditional standards upside down," ARTnews 77, no. 4 (1978), 76.

${ }^{210}$ Howell, "Sight Unseen in Plain Sight," 14.

${ }^{211}$ Kukielski, "Closed on Tuesday," 258.

${ }^{212}$ Latour, Reassembling the Social, 71.

${ }^{213}$ Latour, Reassembling the Social, 72.

${ }^{214}$ Keane, "Signs Are Not the Garb of Meaning," 201. 


\section{REFERENCES}

Baltz, Lewis. “KONSUMERTERROR: Late-Industrial Alienation.” Aperture no. 96 (Fall 1984): 4-7, 76.

Barthes, Roland. Camera Lucida: Reflections on Photography. Translated by Richard Howard. New York: Hill and Wang, 1980.

. Mythologies. Translated by Richard Howard and Annette Lavers. New York: Hill and Wang, 2012.

. The Rustle of Language. Translated by Richard Howard. Berkeley, CA:

Universty of California Press, 1989.

Batchen, Geoffrey. "Ectoplasm: Photography in the Digital Age." In Over Exposed: Essays on Contemporary Photography, Edited by Carol Squires. 9-23. New York: The New Press, 1999.

Baudrillard, Jean. Simulacra and Simulation. Translated by Sheila Faria Glaser. Ann Arbor, MI: The University of Michigan Press, 1994.

Bell, Tiffanny. “Eve Sonneman's Progressions in Time.” Artforum 18, no. 2 (1978): 5659.

Benjamin, Walter. "Little History of Photography." In Selected Writings Volume 2: 19271934, Edited by Michael W. Jennings, Howard Eiland, and Gary Smith.

Translated by Rodney Livingstone and Others, 507-30. Cambridge, MA: The Belknap Press of Harvard University Press, 1999.

."The Paris of the Second Empire in Baudelaire." In The Writer of Modern Life: Essays on Charles Baudelaire, Edited by Michael W. Jennings. Translated by Howard Eiland, Edmund Jephcott, Rodney Livingston, and Harry Zohn, 46-133. Cambridge, MA: The Belknap Press, 2006

. "The Work of Art in the Age of its Technological Reproducibility." In The Work of Art in the the Age of its Technological Reproducibility and Other Writings on Media, Edited by Michael W. Jennings, Brigid Doherty, and Thomas Y. Levin. Translated by Edmund Jephcott, Rodney Livingstone, Howard Eiland, and Others, 19-55. Cambridge, MA: The Belknap Press, 2008. 
Bennett, Jane. Vibrant Matter: A Political Ecology of Things. Durham, NC: Duke University Press, 2010.

Borges, Jorge Luis. “On Exactitude in Science.” In Collected Fictions. Translated by Andrew Hurley, 345. New York: Viking, 1998.

Bourdieu, Pierre. Photography: a Middlebrow Art. Translated by Shaun Whiteside. Cambridge: Polity Press, 1990.

Calvino, Italo. "The Adventure of the Photographer." In Difficult Loves. Translated by William Weaver, Archibald Colquhoun, and Peggy Wright, 220-35. New York: Harcourt Brace Jovanovich, 1984.

William Christenberry, Edited by Michael Famighetti. New York: Aperture Foundation, 2006. Exhibition catalog.

Christenberry, William and Susanne Lange. William Christenberry: Working From Memory. Göttingen: Steidl, 2008.

Collins, John. "DAVID ASKEVOLD, John Gibson Gallery; STEPHEN SHORE, Light Gallery; MARK COHEN, Light Gallery; BILL DANE, The Museum of Modern Art; JOHN MARMARAS, Studio Show." Artforum 12, no. 7 (1974): 74-77.

Dahó, Marta. “Stephen Shore: The Paradoxes of Transparency.” In Stephen Shore. 9-21. New York: Aperture, 2014. Exhibition catalog.

Derrida, Jacques. Copy, Archive, Signature: A Conversation on Photography, Edited by Gerhard Richter. Translated by Jeff Fort. Stanford, CA: Stanford University Press, 2010 .

De Salvo, Donna. "Every Picture." In Elizabeth Sussman and Thomas Weski, William Eggleston Democratic Camera: Photographs and Video, 1961-2008. 253-55. New York: Whitney Museum of American Art, 2008. Exhibition catalog.

Eauclaire, Sally. The New Color Photography. New York: Abbeville Press, 1981.

Eco, Umberto. "On the Impossibility of Drawing a Map of the Empire on a Scale of 1 to 1.” In How to Travel with a Salmon \& Other Essays. Translated by William Weaver, 95-106. New York: Harcourt Brace \& Company, 1994.

Eggleston, William. Election Eve. Göttingen, Germany: Steidl, 2017.

Evans, Walker. "Photography." In Quality: its Image in the Arts, Edited by Louis Kronenberger. 169-211. New York: Atheneum, 1969. 
Foucault, Michel. The Archeology of Knowledge and The Discourse on Language. Translated by A. M. Sheridan Smith. New York: Vintage Books, 1972.

Mark Haworth-Booth. "William Eggleston: An Interview." History of Photography 17, no. 1 (Spring 1993): 49-53.

Holborn, Mark. Introduction to William Eggleston Ancient and Modern. 11-26. New York: Random House, 1992. Exhibition catalog.

Howell, John. "Sight Unseen in Plain Sight." Aperture, no. 165 (Winter 2001): 1-19.

Keane, Webb. "Signs Are Not the Garb of Meaning: On the Social Analysis of Material Things." In Materiality, Edited by Daniel Miller, 182-205. Durham, NC: Duke University Press, 2005.

Kernan, Nathan. "William Eggleston's 'Democratic Photography' The Los Alamos Project." Art on Paper 6, no. 2 (November-December 2001): 64-69.

Kracauer, Siegfried and Thomas Y. Levin. "Photography." Critical Inquiry 19, no. 3 (Spring 1993): 421-36.

Kukielski, Tina. "Closed on Tuesdays: Some Place in These Pictures.” In Elizabeth Sussman and Thomas Weski, William Eggleston Democratic Camera: Photographs and Video, 1961-2008. 257-261. New York: Whitney Museum of American Art, 2008. Exhibition catalog.

Latour, Bruno, Emilie Hermant, and Patricia Reed. Paris: Invisible City. Bruno Latour, 2004. http://www.bruno-latour.fr/virtual/EN/index.html. 14 October 2017.

Latour, Bruno. Reassembling the Social: An Introduction to Actor-Network-Theory. Oxford: Oxford University Press, 2005.

. "Why Has Critique Run Out of Steam? From Matters of Fact to Matters of Concern." Critical Inquiry 30, no. 2 (Winter 2004): 225-248.

MacCannell, Dean. The Tourist: A New Theory of the Leisure Class. Berkeley, CA: The University of California Press, 1999.

McDonald, Jessica. “'An Honest Sense of Place:' Reconsidering John Szarkowski's The Face of Minnesota." Photography \& Culture 1, no. 2 (November 2008): 211-226.

Navarro, Justo. "What Remains of Time: The Present and Ex-Votos." In William Christenberry. 41-53. New York: D. A. P., 2013. Exhibition catalog.

Nesbit, Molly. Atget's Seven Albums. New Haven, CT: Yale University Press, 1992. 
Olin, Margaret. "Touching Photographs: Roland Barthes's 'Mistaken' Identification.” Representations 80 (Autumn 2002): 99-118.

Ritchin, Fred. After Photography. New York: W. W. Norton \& Company, 2009. . Bending the Frame: Photojournalism, Documentary, and the Citizen. New York: Aperture, 2013.

Sekula, Allan. "The Body and the Archive." In The Contest of Meaning: Critical Histories of Photography. Edited by Richard Bolton. 342-89. Cambridge, MA: The MIT Press, 1989.

Shore, Stephen. American Surfaces. London: Phaidon Press Limited, 2005.

Szakowski, John. Introduction to William Eggleston's Guide. 5-14. New York: Museum of Modern Art, 1976. Exhibition catalog. . Mirrors and Windows: American Photography Since 1960. New York: The Museum of Modern Art, 1978. Exhibition catalog.

Tagg, John. The Disciplinary Frame: Photographic Truths and the Capture of Meaning. Minneapolis: University of Minnesota Press, 2009.

Thornton, Gene. "The New Photography: Turning Traditional Standards Upside Down." ARTnews 77, no. 4 (1978): 74-78.

Weski, Thomas. “'I Can't Fly, But I Can Make Experiments."” In Elizabeth Sussman and Thomas Weski, William Eggleston Democratic Camera: Photographs and Video, 1961-2008. 1-19. New York: Whitney Museum of American Art, 2008. Exhibition catalog. 


\section{CURRICULUM VITA}

NAME: Joel Alton Darland

ADDRESS: 502 Joan Ave.

Elizabethtown, KY 42701

DOB: $\quad$ Elizabethtown, Kentucky - February 26, 1988

EDUCATION

\& TRAINING: $\quad$ B.A., Studio Art

Georgetown College

2007-10

M.A., Art(c) and Art History

University of Louisville

2017-18

AWARDS: $\quad$ Outstanding Graduate in Fine Arts

University of Louisville

2018

Cressman Scholarship

University of Louisville

2018

PROFESSIONAL SOCIETIES: American Alliance of Museums

\section{College Art Association}

PUBLICATIONS: "Small is More than Just a State of Mind." Under Main. 2017.

http://www.under-main.com/arts/small-is-more-than-just-a-stateof-mind/.

"Real Virtuality." Under Main. 2017.

http://www.under-main.com/newsletter/real-virtuality/.

“Dredging Memory and Disaster.” Under Main, 2017. http://www.under-main.com/arts/dredging-memory-and-disaster/. 
"Out of Time: Francisco Goya, Kara Walker, and Grotesque Spaces." In in Between: Time and Transition. Louisville, KY: Schneider Hall Galleries, 2018. Exhibition Catalog. 